\title{
Environmental Control Technology for Shale Oil Wastewaters
}
B. W. Mercer
M. J. Mason
W. Wakamiya
R. R. Spencer
N. E. Bell
C.J. English
R. G. Riley

September 1982

Prepared for the U.S. Department of Energy under Contract DE-AC06-76RLO 1830

Pacific Northwest Laboratory Operated for the U.S. Department of Energy by Battelle Memorial Institute 


\title{
DISCLAIMER
}

This report was prepared as an account of work sponsored by an agency of the United States Government. Neither the United States Government nor any agency thereof, nor any of their employees, makes any warranty, express or implied, or assumes any legal liability or responsibility for the accuracy, completeness, or usefulness of any information, apparatus, product, or process disclosed, or represents that its use would not infringe privately owned rights. Reference herein to any specific commercial product, process, or service by trade name, trademark, manufacturer, or otherwise, does not necessarily constitute or imply its endorsement, recommendation, or favoring by the United States Government or any agency thereof. The views and opinions of authors expressed herein do not necessarily state or reflect those of the United States Government or any agency thereof.

\author{
PACIFIC NORTHWEST LABORATORY \\ operated by \\ BATTELLE \\ for the \\ UNITED STATES DEPARTMENT OF ENERGY \\ under Contract DE-AC06-76RLO 1830
}

\begin{tabular}{|c|c|}
\hline \multicolumn{2}{|c|}{$\begin{array}{c}\text { National Technical Information Service } \\
\text { United States Department of Commerce } \\
5285 \text { Port Royal Road } \\
\text { Springtield. Virginia } 22151\end{array}$} \\
\hline \multicolumn{2}{|c|}{$\begin{array}{l}\text { NTIS Price Codes } \\
\text { Microfiche A01 }\end{array}$} \\
\hline \multicolumn{2}{|c|}{ Printed Copy } \\
\hline Pages & $\begin{array}{l}\text { Price } \\
\text { Codes }\end{array}$ \\
\hline $001-025$ & $\mathrm{~A} 02$ \\
\hline 026.050 & $\mathrm{AOB}$ \\
\hline $051-075$ & $\mathrm{AOA}$ \\
\hline $076-100$ & A05 \\
\hline $101-125$ & $A 06$ \\
\hline $126-150$ & A0? \\
\hline $151-175$ & $A 08$ \\
\hline $176 \cdot 200$ & $A 09$ \\
\hline $201 \cdot 225$ & $A 010$ \\
\hline 226.250 & A011 \\
\hline $251-275$ & $A 012$ \\
\hline $276 \cdot-300$ & $A 013$ \\
\hline
\end{tabular}



B. W. Mercer
W. Wakami ya
N. E. Bell
M. J. Mason
R. R. Spencer
C. J. English
R. G. Riley

September 1982

Prepared for

Assistant Secretary for Environmental

Protection, Safety and Emergency Preparedness

Division of Environmental Control Technology

the U.S. Department of Energy

under Contract DE-ACO6-76RLO 1830

Pacific Northwest Laboratory

Richland, Washington 99352 


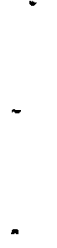




\section{CONTENTS}

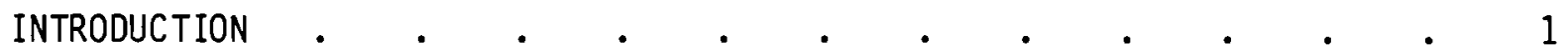

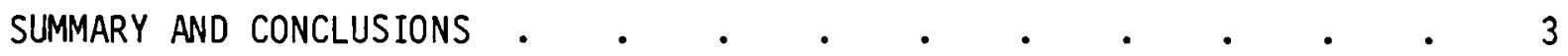

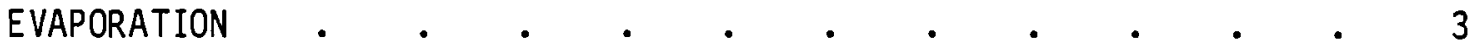

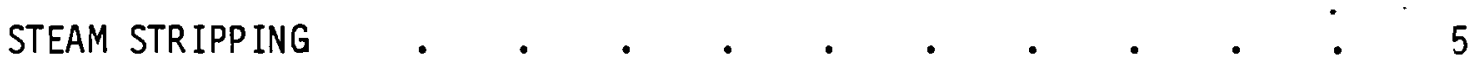

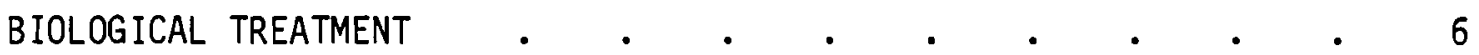

ACTI VATED CARBON ADSORPTION $\quad$ •

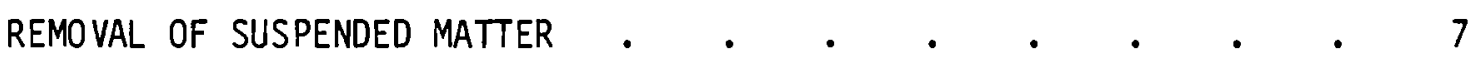

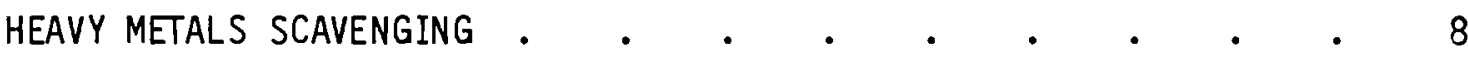

WET AIR OXIDATION

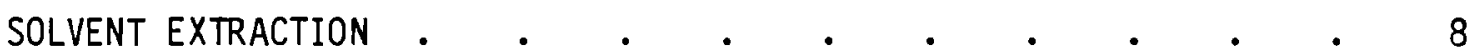

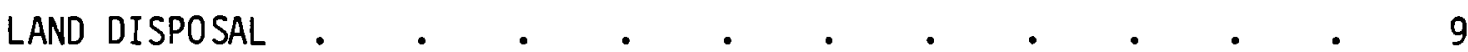

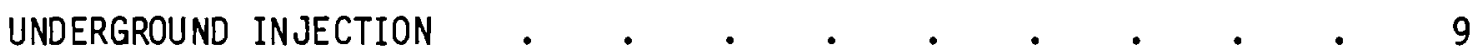

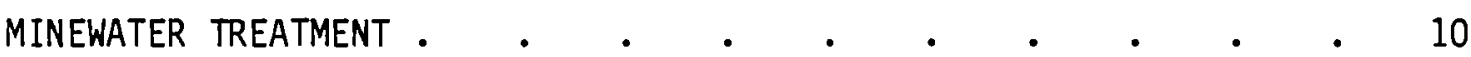

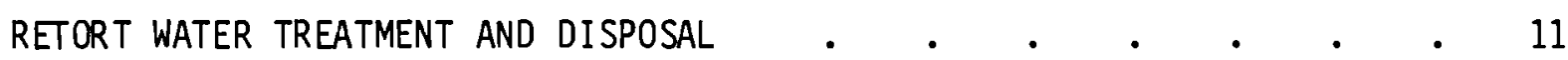

RETORT WATER CHARACTERISTICS AND DISCHARGE/REUSE REQUIREMENTS • 11

Retort Water Quality $\quad . \quad$. $\quad . \quad$. $\quad . \quad$. 11

Retort Water Volume . . . . . . . . . . 12

Discharge Limitations $\quad . \quad$. $\quad . \quad$. $\quad . \quad$. 13

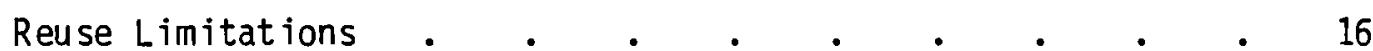

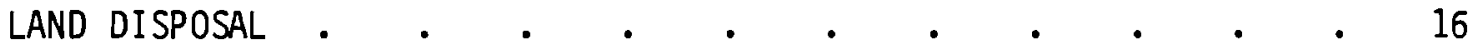

Pollutant Removal Mechanisms . . . . . . . . 17

Land Application Methods . $\quad . \quad$. $\quad . \quad$. 17

Suitability for Retort Water . $. \quad . \quad . \quad . \quad . \quad 18$

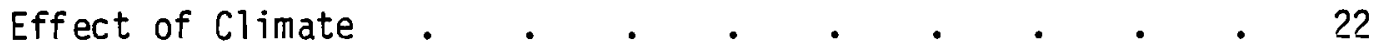


UNDERGROUND INJECTION

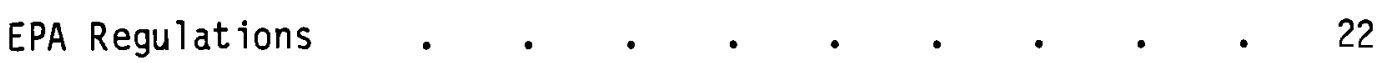

Wastewater Quality Requirements for Injection . . . 25

Disposal Site Selection . . . . . . . . . . 26

Suitability of Retort Water for Underground Injection . $\quad 27$

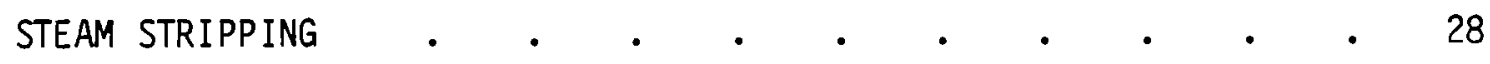

Process Description. . . . . . . . . 28

Bench-Scale Treatability Studies . . . . . . 29

Removal of Alkylpyridines . . . . . . . . 32

LIQUID-LIQUID EXTRACTION • • • • • • • • • • • 39

Process Description . . . . . . . . . 41

Batch Equilibrium Experiments . . . . . . . 43

BIOLOGICAL TREATMENT • • • • • • • • • • 46

Process Description. . $. \quad . \quad . \quad . \quad . \quad . \quad .46$

Treatment Studies . $. \quad . \quad$.

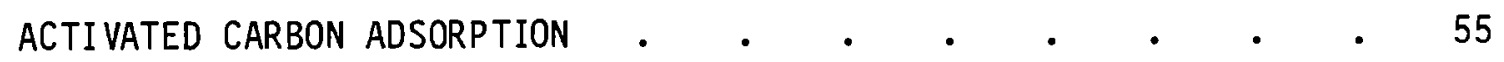

Process Description . . . . . . . . . . 55

Bench-Scale Treatability Studies • . . . • . 56

WET AIR OXIDATION

Process Description. . . . . . . . . 60

Experimental Results . . • . • • • • 52

REMOVAL OF HEAVY METALS AND SUSPENDED SOLIDS • • • • • •

Precipitation of Arsenic with Ferric Hydroxide . • $\quad 64$

Heavy Metals and Boron in Treated Effluents . • • • 64

Chemical Coagulation and Flocculation of Raw Retort water . 65

Alum Coagulation of Biotreated Water . . . . . 67 


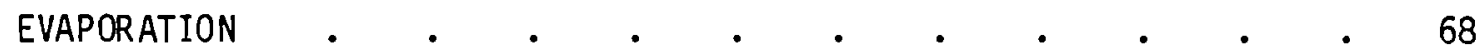

Phase I - Laboratory Tests . . . . . . . 69

Phase II - Bench-Scale Evaporator Test . . . . . 69

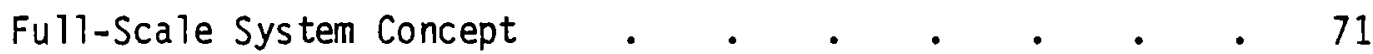

Disposal or Reuse of Evaporator Product Streams . . . 74

MINEWATER TREATMENT •

ACTI VATED ALUMINA SORPTION AND ION EXCHANGE $\quad$ • $\quad$ • $\quad$ • $\quad 79$

CHEMICAL TREATMENT FOR FLUORIDE REMOVAL • • • • • • • • $\quad$ • 79

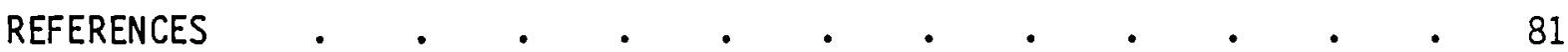

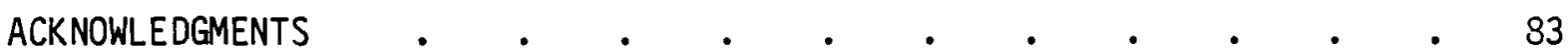




\section{FIGURES}

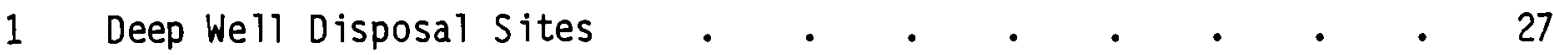

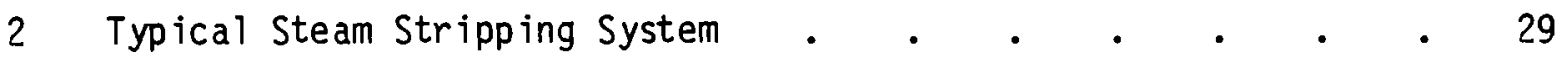

3 Total Ion Mass Chromatogram of Components in Solvent Extracts of Condensate, Effluent and Feed . . . . . . . 35

4 Mass Spectrum of $C_{2}$-Pyridine $(R T=13.5 \mathrm{~min}) \quad$. $\quad$. . . 36

5 Mass Spectrum of $C_{3}$-Pyridine $(R T=16.1 \mathrm{~min}) \quad$. $\quad$ • . . 37

6 Mass Spectrum of $\mathrm{C}_{4}$-Pyridine $(\mathrm{RT}=23.3 \mathrm{~min}) \quad . \quad$. . . 38

7 Mass Spectrum of 3,5,5-trimethyl-2-cyclohexen-1-one $(\mathrm{RT}=22.0 \mathrm{~min}) \quad . \quad . \quad . \quad . \quad . \quad . \quad . \quad . \quad . \quad . \quad . \quad 39$

8 Mass Spectrum of Acridine (RT $=52.1 \mathrm{~min}$ ) . . . . . . 41

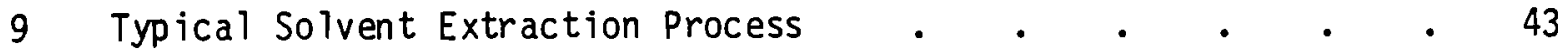

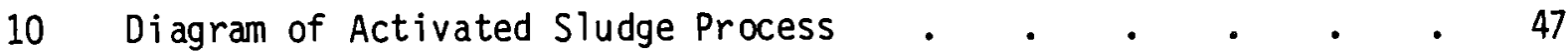

Organic Carbon Influent, Effluent and Loading Values
with PAC Treatment. . . . . . . . . . 51

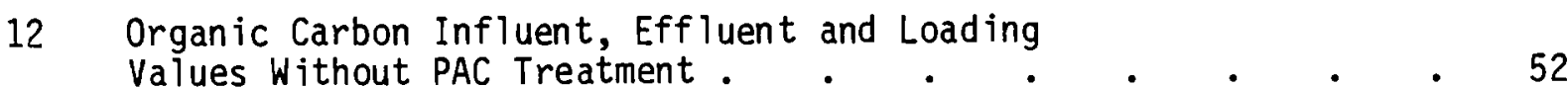

13 Removal of TOC, COD and Thiocyanate with PAC Treatment . . 53

Removal of TOC, COD and Thiocyanate Without
PAC Treatment. . . . . . . 54

15 Simplified Flowsheet of a Granular Activated Carbon Column with a Thermal Regeneration System $. \quad . \quad . \quad . \quad . \quad 55$

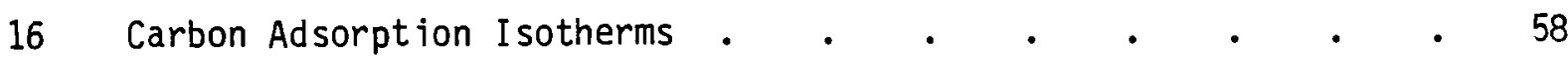

17 Activated Carbon Treatment TOC Removal • . . . . . . 59

18 Basic Flowsheet of the Wet Air Oxidation Process . . . . 60

19 Effect of WAO Process Variables on COD Removal . $\quad . \quad$. $\quad 61$

20 Laboratory Scale Wet Air Oxidation Apparatus • • • • 62

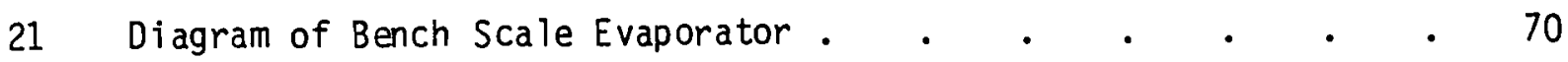




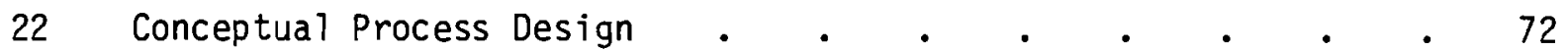

23 Fluoride and Boron Breakthrough Curves . . . . . . 80

\section{$\underline{\text { TABLES }}$}

1 Concentration Ranges for Major Components of Retort Waters . . 11

2 Minor Elements of Simulated In Situ Retort Waters . . . . 13

3 Elemental Analys is of Geokinetics In Situ Retort Water . . 14

4 Tentative Criteria for Disposal of Shale $0 i 1$ Effluents

to Surface Waters . $. . \quad . \quad . \quad . \quad . \quad . \quad 15$

5 Recommended Limits of Specific Ions in Irrigation Water $\quad$ - $\quad 21$

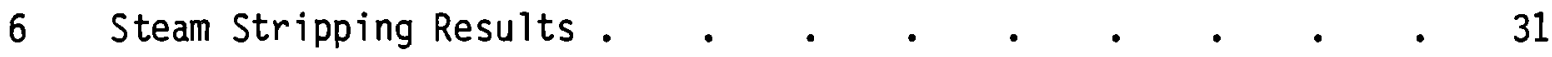

7 Amounts and Distribution (\%) of Alkylpyridines in Samples

Collected from Run 2 Steam Stripping Experiment . . . . 38

8 Concentrations ( $\mathrm{mg} / \mathrm{l}$ ) of Alkylpyridines in Solvent Extraction

Experiments . . . . . . . . . . . . 44

9 Equilibrium Distributions of Alkylpyridines . . . . . . 45

10 Feed Compositions for Activated Sludge Test Reactors . . . 50

11 Comparison of Pollutant Removals with Activated Sludge

12 COD and Suspended Solids Data for WAO Tests with Paraho

$13 \quad$ COD and Suspended Solids Data for WAO Tests with Occidental

14 Heavy Metals and Boron in Geokinetics No. 3 Effluents . . $\quad 65$

15 Heavy Metals and Boron in Geokinetics No. 4 Effluents . . . 65

16 Effect of Polymer Type and Dosage on Removal of Suspended
Solids from Retort Water

17 Alum Coagulation of Raw Geokinetics Retort Water . . . . . 68 
18 Results of Alum/Polymer Coagulation Tests on Biotreated Retort Water . . . . . . . . . . . 68

19 Average Composition of Bench Model Evaporator Inputs and Outputs During Five Days of Continuous Operation . . . $\quad$ • 71

20 Process Flow Rates and Temperatures . . . . . . . . 73

21 Results of Analysis of Geokinetics Retort Water Concentrate . 76

22 Comparison of Results from Crystallization With and Without

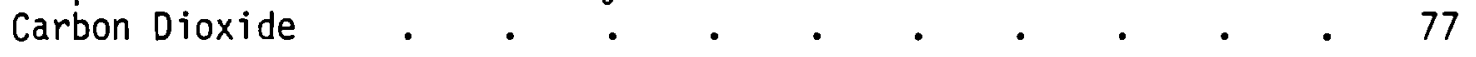




\section{INTRODUCTION}

This report summarizes the results of studies conducted at Pacific Northwest Laboratory from 1976 to 1982 on environmental control technology for shale oil wastewaters. Experimental studies conducted during the course of the program were focused largely on the treatment and disposal of retort water, particularly water produced by in situ retorting of oil shale. Retort water is generally considered to be the most highly polluted wastewater produced by shale oil recovery facilities. This waste stream has a broad spectrum of both organic and inorganic pollutants, the removal of which presents a difficult challenge to the waste treatment engineer.

Retort water management is not visualized as a severe problem for surface retorting facilities because the water can be used with minimal treatment for moisturizing spent shale. Moisturization is essential for finely divided or powdery spent shale, such as that produced by the Tosco II Process, to permit adequate compaction of the spent shale at the disposal site. Moisturization is not essential for compaction of coarse types of spent shale, although it can be beneficial. No discharge of retort water is currently anticipated from surface retorting facilities since this water will either be used for moisturizing spent shale or for some other consumptive purpose.

Management of retort water produced by in situ operations is expected to be a problem where the volume of this wastewater exceeds the amount that can be reused by these operations. In situ shale oil recovery usually produces more retort water than surface retorting. The ratio of the volume of in situ retort water to that of the oil produced is extremely variable. The frequently cited ratio of one barrel of water produced with each barrel of 0 il represents a considerable volume of retort water (about 2 million gallons per day) for an in situ facility producing 50,000 barrels of oil per day. In the case of a modified in situ operation some of the retort water could be used for spent shale moisturization if a surface retort facility is employed to process shale removed from the subsurface retorts. Retort water can also be used to produce steam for injection into the retorts for enhanced oil recovery. Although reuse without treatment is possible for much if not all of the retort water 
produced under favorable conditions (e.g., dry shale retorting with steam injection), it is anticipated that considerable quantities of this wastewater will be produced if in situ retorting is practiced on a broad scale utilizing true in situ methods without steam injection and modified in situ methods in wet shale zones. Therefore, suitable disposal methods or means of upgrading the quality of the wastewater for additional reuse purposes must be sought to avoid substantial degradation of receiving water quality near these facilities.

A preliminary investigation of minewater treatment was also undertaken during this program. This water is pumped from oil shale mines or in situ operational zones to dewater the shale prior to mining or retorting. Minewater may be polluted with fluoride, boron or high dissolved salt concentration which will prevent unrestricted release of this water to surface receiving streams.

Although the shale oil industry is largely in the pilot plant/demonstration phase, the codevelopment of adequate wastewater control technology is necessary for several reasons: 1) prevention of environmental damage as a result of the pilot $\mathrm{plant/demonstration} \mathrm{operations} \mathrm{themselves;} \mathrm{2)} \mathrm{control}$ techniques may produce water which can be reused in the production process and this should be taken into account in the design of full-scale facilities; 3) adequacy of control technology should be fully assessed at an early stage to obviate delays and problems in construction and/or operation of full-scale production facilities; and 4) characterization of effluent discharges from pilot plant/demonstration operations will facilitate other environmental and health assessments. The major oil shale deposits in the United States are located in Colorado, Wyoming, and Utah. Therefore, developers of the shale oil industry must be fully cognizant of the importance of conservation of the limited water supplies in this area. 


\section{SUMMARY AND CONCLUSIONS}

Alternative methods were evaluated for the treatment and disposal of retort water and minewater. Treatment and disposal processes evaluated for retort water include evaporation for separation of water from both inorganic and organic pollutants; steam stripping for ammonia and volatile organics removal; activated sludge and anaerobic digestion for removal of biodegradable organics and other oxidizable substances; carbon adsorption for removal of nonbiodegradable organics; chemical coagulation for removal of suspended matter and heavy metals; wet air oxidation and solvent extraction for removal of organics; and land disposal and underground injection for disposal of retort water. Methods for the treatment of minewater include chemical processing and ion exchange for fluoride and boron removal. Preliminary cost estimates are given for several retort water treatment processes. A summary of this work with major conclusions is presented below.

\section{EVAPORATION}

- Results of bench-scale evaporation tests with Geokinetics in situ retort water were quite encouraging for establishing evaporation as an effective method for recovering relatively high quality water for reuse.

- The $95 \mathrm{~L} /$ day test evaporator used in these studies was effective in removing better than $90 \%$ of the inorganic carbon, conductivity, alkalinity, total solids, and suspended solids. Organic carbon removal was about $70 \%$, and ammonia removed through the combination of the stripper and the evaporator was $86 \%$.

- The heat transfer coefficient, $U$, averaged to $2610 \mathrm{~J} / \mathrm{m}^{2} \cdot \mathrm{s} \cdot{ }^{\circ} \mathrm{K}$ during the test evaporator operation. A coating formed on the heat transfer surface and the $U$ value was unsteady during the first two days but reached a relatively steady state near the average $U$ value for the final three days of operation. Further testing is required to determine the rate of reduction for the $U$ value, and, thereby, the heat transfer surfaces cleaning cycle requirements. For cleaning the heat transfer surfaces, the most effective method was a circulating $5 \%$ acid solution. 
- Slight amounts of foaming occurred on startup of the bench-scale evaporator. After the concentration factor reached 10, foaming was negligible and, therefore, no requirement for antifoam is anticipated.

- The condensate produced may be suitable for irrigation water. Conductivity, dissolved solids, and the sodium adsorption ratio were all under the hazard limit for irrigation of cover crops. A plant germination and growth study is needed to determine if an organic carbon concentration of $500 \mathrm{mg} / \mathrm{L}$ is harmful to crops. The residual ammonia level of the distillate should provide some potential nutrient value.

- Greater than $99 \%$ removal of total organic carbon (TOC) was achieved with combined activated sludge and activated carbon treatment of the evaporator condensate. Greater than $98 \%$ removal of TOC was achieved with activated carbon treatment alone which suggests that activated carbon treatment may be sufficient by itself.

- The results of crystallization studies indicate that recovery of soda ash is possible from retort water concentrate, but the loss of organic carbon during the evaporation step offsets most of the potential gain in the fuel value of the residue.

- Sump concentrate disposal may be difficult and expensive. Heat of combustion for the concentrate was not sufficient to recommend incineration as a method of disposal. This waste may be classified as hazardous waste since concentration of arsenic and selenium exceed regulatory limitations.

- Fixation of residue from evaporation of Geokinetics retort water with asphalt, sulfur or a mixture of these two materials shows potential for preventing arsenic from leaching above RCRA guidelines (EP Toxicity Test).

- The use of retort water concentrate from the evaporation process may be a possible source of makeup salt for the Kraft wood pulping process.

- The cost for evaporation with ammonia stripping pretreatment was found to be competitive to biological and physical-chemical methods of treatment. The estimated cost for evaporation ranged from $\$ 6.78$ to $\$ 8.52 / 1000 \mathrm{ga} 1$ compared to $\$ 10.78$ to $\$ 24.75 / 1000$ gal for biological and physical-chemical methods of treatment (1980 costs for 2 mgd facility). 


\section{STEAM STRIPPING}

- Steam stripping of retort water is expected to be required either as a pretreatment step for additional processing by itself prior to use of the water for dust control or moisturizing spent shale. Steam stripping serves to remove volatile constituents such as ammonia and hydrogen sulfide which would interfere with biological treatment and cause substantial air and water pollution if the retort water is disposed to the environment.

- Results with a bench-scale steam stripper showed greater than $95 \%$ removal of ammonia from Geokinetics retort water without adding lime or other alkaline material. TOC and total alkalinity were reduced $18 \%$ and $70 \%$ respectively. No hydrogen sulfide was present in Geokinetics retort water.

- Ammonia removal exceeding $98 \%$ was achieved with Paraho retort water when $90 \mathrm{~g} / \mathrm{L}$ of sodium hydroxide was added to the steam stripper feed. Ammonia removal dropped to $38 \%$ when no sodium hydroxide was added. Hydrogen sulfide was also not present in the Paraho retort water used in these studies.

- Steam stripping was found to be effective for removing alkylpyridines from Paraho retort water. Alkylpyridines are organic substances that were found to migrate to ground and surface water in a drainage located adjacent to the Anvil Points $0 i 1$ Shale Facility at Rifle, Colorado.

- The foaming tendency of retort water required careful attention to maintaining low liquid levels in the reboiler of the bench scale stripper to avoid flooding the packed column.

- Some fouling of the stripper packing was observed when processing Geokinetics retort water. Use of trays, which can be readily cleaned, may be necessary in a full-scale steam stripper.

- Preliminary steam stripping costs for Geokinetics in situ retort water were estimated to be in the range of $\$ 4.82$ to $\$ 12.13 / 1000 \mathrm{gal}$. 
BIOLOGICAL TREATMENT

- Anaerobic digestion of retort water does not appear practical due to the presence of toxicants which interfere with microbial activity. Digestion of an undiluted simulated in situ retort water was achieved, but a large dose of powdered activated carbon $(2000 \mathrm{mg} / \mathrm{L})$ was added to the digester to overcome toxicity problems.

- Several initial attempts to acclimate activated sludge cultures to Geokinetics in situ retort water were not successful due to toxicity problems. The high bicarbonate content of the retort water tested results in carbon dioxide stripping in the aeration chamber and $\mathrm{pH}$ levels above optimum for this process.

- Successful acclimation of an activated sludge culture was achieved with careful pH control $(7.0 \pm 0.5)$ and a long acclimation period using activated carbon treated retort water. The difficulty in achieving acclimation suggests potential difficulty in plant application of this treatment process.

- As much as $70 \%$ of the chemical oxygen demand (COD) and $65 \%$ of the total organic carbon (TOC) were removed by activated sludge with $300 \mathrm{mg} / \mathrm{L}$ PAC addition. Consistantly high thiocyanate removal (>94\%) was maintained with PAC addition.

- Comparison of activated sludge treatment with and without $300 \mathrm{mg} / \mathrm{L}$ PAC addition under similar loading conditions $(0.71$ to $0.79 \mathrm{lb}$ of $\operatorname{COD} / 1 \mathrm{~b}$ of mixed liquor volatile solids) did not reveal a significant difference for TOC and COD removal ( 56 and $66 \%$, respectively), but thiocyanate removal was superior with PAC addition ( $99 \%$ versus $72 \%$ ).

- Thiosulfate was readily oxidized by activated sludge treatment.

- A relatively 1 arge quantity of strong mineral acid (e.g., 58 1b of $100 \%$ $\left.\mathrm{H}_{2} \mathrm{SO}_{4} / 1000 \mathrm{gal}\right)$ is required to maintain optimum $\mathrm{pH}$ levels for effective activated sludge treatment. Recarbonation with $\mathrm{CO}_{2}$ or stack gas containing $\mathrm{CO}_{2}$ is not practical due to the large bicarbonate concentration in the retort water. 
- Preliminary cost estimates for activated sludge treatment of Geokinetics retort water ranged from $\$ 3.09$ to $\$ 5.65 / 1000$ gal $(1980$ costs for $2 \mathrm{mgd}$ facility).

\section{ACTIVATED CARBON ADSORPTION}

- Activated carbon adsorption is much more effective for removing dissolved organic matter from biotreated retort water than nonbiotreated retort water. Isotherm data at $\mathrm{pH} 7$ and $150 \mathrm{mg} / \mathrm{L}$ equilibrium TOC concentration indicate only $22 \mathrm{mg} / \mathrm{L}$ TOC adsorbed per gram of carbon for nonbiotreated retort water, compared to $100 \mathrm{mg} / \mathrm{L}$ TOC adsorbed per gram of carbon for biotreated retort water.

- Activated carbon column results show rapid breakthrough of TOC with nonbiotreated retort water. Breakthrough of $10 \%$ of the feed TOC is reached after 8 bed volumes of nonbiotreated retort water, compared to 50 bed volumes of biotreated retort water.

- Activated carbon adsorption is effective for removal of odor and color, whereas biological treatment has little effect on these parameters.

- Activated carbon adsorption is highly effective for removing copper from biotreated retort water.

- Preliminary estimated costs for activated carbon treatment of activated sludge effluent were in the range of $\$ 2.13$ to $\$ 5.65 / 1000$ gal (1980 costs for 2 mgd facility).

\section{REMOVAL OF SUSPENDED MATTER}

- Only a limited number of tests were conducted on removal of suspended matter from raw retort water because samples of this wastewater were at least two weeks old upon receipt at the laboratory. It is believed that meaningful results for sedimentation and coagulation-flocculation tests can only be obtained using fresh retort water that has been carefully processed to simulate plant operating conditions. 
- A cationic polymer appeared to be superior to either an anionic or neutral polymer for promoting suspended solids settling from raw Geokinetics retort water.

- Alum treatment with polymer addition for coagulation and flocculation was not successful for clarifying raw Geokinetics retort water.

- Biotreated retort water was successfully clarified with $300 \mathrm{mg} / \mathrm{L}$ alum and $1 \mathrm{mg} / \mathrm{L}$ anionic poiymer.

\section{HEAVY METALS SCAVENGING}

- Treatment of steam-stripped Geokinetics retort water with $100 \mathrm{mg} / \mathrm{L} \mathrm{Fe}^{+3}$ (as $\mathrm{FeCl}_{3}$ ) at $\mathrm{pH} 6.0$, or $100 \mathrm{mg} / \mathrm{L} \mathrm{Fe}{ }^{+3}$ with $32 \mathrm{mg} / \mathrm{L} \mathrm{Mn}^{+2}$ or $\mathrm{Mn}^{+7}$ at $\mathrm{pH}$ 7.0 reduced arsenic from $4.1 \mathrm{mg} / \mathrm{L}$ to less than $1 \mathrm{mg} / \mathrm{L}$. Additional treatment of the same retort water did not reduce arsenic below $0.8 \mathrm{mg} / \mathrm{L}$, which indicates either a complex or organic form of arsenic that is not amenable to precipitation-scavenging by this technique.

- Copper was reduced by a factor of 2.6 by $\mathrm{Fe}(\mathrm{OH})_{3}-\mathrm{MnO}_{2}$ scavenging, but $\mathrm{Co}$ and $B$ were reduced by less than a factor of two.

\section{WET AIR OXIDATION}

- Results of wet air oxidation (WAO) experiments with Paraho retort water show $59 \%$ and $83 \%$ cOD reduction at $20 \mathrm{~min}$ and 120 min reaction time respectively at $250^{\circ} \mathrm{C}$ and 2000 psi.

- Thiosulfate in the Paraho retort water appeared to be rapidly oxidized to sulfuric acid by WAO. The $\mathrm{pH}$ of this retort water was reduced from 8.65 to 1.62 during the initial 20 min reaction period.

- WAO of the Paraho retort water not only reduced total COD concentration but also precipitated about half of the remaining COD which may be removed by sedimentation/filtration.

\section{SOLVENT EXTRACTION}

- Solvent extraction experiments were conducted to evaluate this method for removing alkyl pyridines from retort water. 
- Chloroform proved to be the best solvent for removing low molecular weight pyridines from both Paraho and Occidental retort waters with equilibrium distribution coefficients ( $K_{\text {eq }}$ ) in the range 1.2 to 1.3 for the total selected pyridines monitored.

- Toluene and n-octanol appeared to be the least efficient of the solvents tested ( $K_{\text {eq }}$ range 0.05 to 0.21 ) whereas ethylacetate and methylisobutylketone produced intermediate extractions efficiencies ( $\mathrm{K}$ eq range 0.19 to 0.59$)$.

- Solvent extraction was more effective for removal of higher molecular weight pyridines $\left(C_{2}\right.$ and $C_{3}$ pyridines as opposed to lower molecular weight pyridines (pyridine and $C_{1}$ pyridines) which suggests solvent extraction as a supplement to steam stripping. The lower molecular weight pyridines are more volatile and therefore more readily removed by steam stripping.

\section{LAND DISPOSAL}

- Land treatment and disposal of retort water by irrigation or infiltration were investigated as possible alternatives to conventional treatment and disposal.

- The salinity of retort water was found to be too high for irrigation of cover crops needed for effective stabilization of this wastewater.

- The high potential for air and ground water pollution and the need for large storage lagoons during the winter months were further negative factors against the use of 1 and disposal of retort water.

\section{UNDERGROUND INJECTION}

- Underground injection is a potential disposal method for retort water providing no other reasonable alternatives exists and that an acceptable geologic formation is available for receiving this wastewater.

- Underground injection of wastewater is strictly regulated by the EPA or authorized state agencies to protect drinking water sources. 
- It is anticipated that small volumes of retort water (or retort water concentrates) may be disposed by deep well injection but proof of confinement will be difficult to demonstrate for large volumes of retort water because receiving aquifiers have limited storage capability.

\section{MINEWATER TREATMENT}

- Results of bench-scale treatability studies showed that an activated alumina column and a boron specific ion exchange resin column were effective for removing fluoride and boron respectively from CA Tract ground water (minewater to be removed when mining commenced).

- Chemical treatment of a simulated CA Tract ground water with lime and phosphoric acid was effective for removal of fluoride but the cost of chemicals was too high for practical application. 


\section{RETORT WATER TREATMENT AND DISPOSAL}

Wastewater that is coproduced and collected with shale oil during the retorting process is commonly referred to as "retort water." Retort water is typically a highly polluted wastewater which, if discharged in 1 arge quantities without treatment to natural surface receiving waters, would not only place a severe oxygen demand on these receiving waters but would also introduce a substantial load of toxic materials and salinity. Treatment and disposal/reuse alternatives for management of retort water in the developing shale oil industry are discussed in this section.

\section{RETORT WATER CHARACTERISTICS AND DISCHARGE/REUSE REQUIREMENTS}

A thorough characterization of retort water is necessary to properly assess the potential application of treatment processes for the removal of pollutants. Available data on the composition of retort water and quality standards for discharge or reuse are reviewed.

Retort Water Quality

The composition of retort water has been reviewed by Fox and Phillips (1980). Their data have been supplemented with data generated at Pacific Northwest Laboratory to give concentration ranges for major components listed in Table 1.

TABLE 1. Concentration Ranges for Major Components of Retort Waters

\begin{tabular}{lr}
\multicolumn{1}{c}{ Parameter } & Concentration Range \\
\cline { 3 - 3 } Organic carbon & 1 to $40 \mathrm{~g} / \mathrm{L}$ \\
Chemical oxygen demand & 5 to $150 \mathrm{~g} / \mathrm{L}$ \\
Alkalinity, total (as $\mathrm{CaCO}_{3}$ ) & 8 to $111 \mathrm{~g} / \mathrm{L}$ \\
Nitrogen, ammonia & 1 to $30 \mathrm{~g} / \mathrm{L}$ \\
Sulfur, total & 0.01 to $50 \mathrm{~g} / \mathrm{L}$ \\
Solids, dissolved & 1.8 to $24 \mathrm{~g} / \mathrm{L}$ \\
Solids, volatile & 2.1 to $119 \mathrm{~g} / \mathrm{L}$ \\
Conductivity & 15,000 to 193,000 umhos/cm \\
pH & 8.1 to 9.4
\end{tabular}


The total organic carbon content of retort water represents a very complex mixture of organic compounds of which only a small fraction has been identified and quantified. A substantial portion of the organic compounds are polar, aliphatic carboxylic acids being the major components. Most of the nitrogen content of retort water exists as ammonia or ammonium, and the remainder is organically bound in such compounds as pyridines, quinolines, anilines, pyrroles, and indoles. Pyridines are significant because recent studies indicate alkylpyridines are one of the more mobile species of organics in ground water (Riley et al. 1981). Bicarbonate and carbonate are typically major contributors to the alkalinity and to the mineral salt content of retort water. Sulfur may exist in many different forms, both organically bound and as ionic species ranging from sulfide to sulfate. oxidized species such as sulfate, sulfite, and thiosulfate also contribute to the mineral salt content. The chemical oxygen demand (COD) may include contributions from reduced sulfur species as well as organic components. Thiosulfate may be present in relatively large concentrations and contribute as much as $20 \%$ of the $\mathrm{COD}$ and $35 \%$ of the biochemical oxygen demand (BOD) of retort water. The standard $B O D$ test may fail to include the thiosulfate contribution unless special precautions are taken (Wong and Mercer 1979).

The concentrations of minor elements in simulated in situ retort waters are presented in Table 2. Elemental analysis of an actual in situ retort water (Geokinetics) are given in Table 3. Sodium is typically the principal metal ion in these retort waters and a major contributor to the mineral salt content. Arsenic, an EPA priority pollutant, of ten exceeds RCRA guidelines $(5 \mathrm{mg} / \mathrm{L})$ which designate a waste as hazardous.

\section{Retort Water Volume}

The volume of retort water may average 0.4 barrels per barrel of oil produced (Hicks et al. 1980), but is quite variable depending on the type of retorting process employed. The combined production of retort water and gas condensate has ranged from 0.1 to 22 barrels of water per barrel of oil produced (Farrier et al. 1978). The upper value of 22 barrels is believed to include substantial ground water inflow to an in situ retort and is probably not representative of full-scale commercial processing. Surface retorts are expected to produce less retort water than in situ retorts. 
TABLE 2. Minor Elements of Simulated In Situ Retort Waters (Fox et al. 1978)

\begin{tabular}{|c|c|c|c|}
\hline \multirow[b]{2}{*}{ Element } & \multicolumn{3}{|c|}{ Concentration in $\mathrm{mg} / \mathrm{L}(\mathrm{a})$} \\
\hline & Minimum & Maximum & Average \\
\hline Aluminum & 0.041 & 16.6 & \\
\hline Arsenic & 0.46 & 10 & 1.8 \\
\hline Barium & 0.002 & 0.47 & 0.07 \\
\hline Beryllium & 0.001 & 0.001 & \\
\hline Bromine & 0.001 & 1.94 & 0.082 \\
\hline Cadmium & 0.001 & 0.005 & \\
\hline Calcium & 0 & 94 & 7.6 \\
\hline Chlorine & 0.007 & 1,910 & \\
\hline Chromium & 0.009 & 0.08 & 0.015 \\
\hline Cobalt & 0.002 & 0.65 & 0.12 \\
\hline Copper & 0.003 & 160 & 0.019 \\
\hline Fluoride & 0.1 & 270 & \\
\hline Iodine & 0.001 & 1.3 & \\
\hline Iron & 0.091 & 77 & 7.6 \\
\hline Lead & 0.002 & 0.83 & \\
\hline Lithium & 0.001 & 7.1 & 0.70 \\
\hline Magnesium & 3.2 & 350 & 22 \\
\hline Manganese & 0.001 & 0.39 & 0.099 \\
\hline Mercury & 0.001 & 0.39 & \\
\hline Molybdenum & 0.033 & 1.2 & \\
\hline Nickel & 0.014 & 2.6 & \\
\hline Potassium & 8 & 120 & 37 \\
\hline Selenium & 0.001 & 1.7 & \\
\hline Silver & 0.001 & 0.23 & \\
\hline Sodium & 45 & 1,600 & 320 \\
\hline Uranium & 0.018 & 93 & \\
\hline Vanadium & 0.004 & 190 & 0.27 \\
\hline Zinc & 0.020 & 15.1 & 0.28 \\
\hline
\end{tabular}

(a) The range given is based on the analysis of up to 18 different waters obtained from 4 simulated in situ oil shale retorts. An average value is given only if 15 or more waters are available.

Discharge Limitations

Sufficient wastewater treatment data were not available to develop guidelines for disposal of retort or process waste water to surface receiving waters. Instead, tentative criteria were established based on State standards (Table 4). Except for total dissolved solids, these values are taken from 
TABLE 3. Elemental Analysis of Geokinetics In Situ Retort water (Mercer et al. 1982)

\begin{tabular}{|c|c|c|}
\hline \multirow[b]{2}{*}{ Parameter } & Concentration (a) & $n^{(a)}, m g / L$ \\
\hline & Minimum & Maximum \\
\hline Antimony & 0.13 & 0.33 \\
\hline Arsenic & 4.1 & 19.2 \\
\hline Boron* & 85 & 120 \\
\hline Cadmi um* & $<0.01$ & $<0.01$ \\
\hline Calcium* & $<1$ & 8.7 \\
\hline Chlorine & 130 & 150 \\
\hline Chromi um & $<0.07$ & 0.1 \\
\hline Cobalt & 0.12 & 0.36 \\
\hline Copper* & $<0.01$ & 0.33 \\
\hline Fluoride & 28 & 29 \\
\hline Iron & $<5$ & 8 \\
\hline Lithium* & 0.20 & 0.48 \\
\hline Magnesi um $\star \star$ & 15 & 100 \\
\hline Molybdenum & 1.5 & 8.4 \\
\hline Potassi um** & 89 & 230 \\
\hline Selenium & 0.22 & 0.31 \\
\hline Sodium & 2200 & 6320 \\
\hline Sulfur ${ }^{\star \star \star}$, sulfate & 250 & 550 \\
\hline Sulfur***, thiosulfate & 814 & 1320 \\
\hline 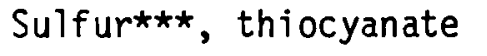 & 127 & 163 \\
\hline Uranium & 0.12 & 0.17 \\
\hline Vanadium & $<0.08$ & 0.1 \\
\hline
\end{tabular}

(a) Determined by neutron activation except where marked by asterisks.

* Analyzed by plasma emission spectroscopy.

** Analyzed by atomic absorption.

$\star \star \star$ Analyzed by ion chromatography. 
TABLE 4. Tentative Criteria for Disposal of Shale 011 Effluents to Surface Waters

\begin{tabular}{|c|c|c|}
\hline No. & Parameter & Limitation \\
\hline 1 & $\mathrm{BOD}_{5}$ & $30 \mathrm{mg} / \mathrm{L}$ \\
\hline 2 & Suspended solids & $30 \mathrm{mg} / \mathrm{L}$ \\
\hline 3 & $0 i 1$ and grease & $\begin{array}{l}10 \mathrm{mg} / \mathrm{L} \text { and no visible } \\
\text { sheen }\end{array}$ \\
\hline 4 & $\mathrm{pH}$ & 6.0 to 9.0 \\
\hline 5 & Settleable solids & Essentially free from \\
\hline 6 & Floating solids & Essentially free from \\
\hline 7 & Taste, odor, color & Essentially free from \\
\hline 8 & Toxic materials & Essentially free from \\
\hline 9 & Total dissolved solids & $500 \mathrm{mg} / \mathrm{L}$ \\
\hline
\end{tabular}
Note: Numbers 1-4 above provide specific limitations for discharge of wastes not covered by other industrial effluent limitation guidelines in the State of Colorado. Numbers 5-8 are standards applicable to receiving waters for Colorado, Utah, and Wyoming. Number 9 is the average total dissolved solids in the Colorado River at Grand Valley, Colorado.

water quality standards and effluent limitations for the states most likely to be involved in shale oil development (Colorado, Utah, and Wyoming). The limitation of $500 \mathrm{mg} / \mathrm{L}$ for total dissolved solids represents an average value for the Colorado River at Grand Valley, Colorado, which is in the vicinity of several planned commercial shale oil recovery operations.

Based on the criteria given in Table 4, discharge of untreated retort water to natural surface receiving waters would be unacceptable for a number of reasons. Retort water has a foul taste and odor and a color varying from light to dark brown. Ammonia probably represents the greatest toxicity problem to aquatic life because of its relatively high concentration. In many cases tenfold dilutions would not be sufficient to reduce arsenic, fluoride, or boron below drinking water or irrigation water quality limitations. 
Potential limitations of disposing retort water to solar evaporation ponds include volatile organics and ammonia which may cause air pollution problems. Ultimately, the concentrate or sludge from the solar evaporation ponds would have to be disposed in a manner consistent with the regulations to be promulgated under the Resources Conservation and Recovery Act (RCRA) of 1976. The presence of soluble toxic substances, such as arsenic and selenium, in the retort water concentrate may render this material hazardous and require special disposal methods to meet RCRA requirements.

Reuse Limitations

Reuse of retort water is possible with little or no treatment for the generation of low pressure steam for injection into an in situ retort. Volatile constituents evaporated along with the water are recycled back to the retort zone with the steam.

Reuse of retort water with minimal treatment is also possible for moisturizing spent shale produced from surface retorts operating in conjunction with modified in situ retorts. The ramifications of adding retort water to the spent shale prior to disposal have not been fully explored.

Reuse of retort water as cooling water has been proposed; however, expensive treatment prior to this use would be required. Furthermore, the salinity of the water would be corrosive to conventional materials such as carbon steel used in cooling systems. Corrosion problems can be circumvented, however, by using materials that resist corrosion (e.g., titanium) in a saline environment but these materials can be very expensive. The stripping of volatile substances from the retort water in a cooling tower places a limitation on the amount of these substances that could be tolerated from an atmospheric pollution standpoint. Reduction of BOD concentrations would probably be required to control slime growths in the cooling system. Chlorine addition to the control slime growths would be very costly because of the high concentrations of reducing substances (e.g., thiosulfate) in the retort water.

\section{LAND DISPOSAL}

Land application as a treatment and disposal method utilizes the interaction between plants and the soil surface to effectively stabilize many 
different types of wastes. Passage of the 1972 Federal Water Pollution Act (PL 92-500) has focused attention on land application as an alternative for effective treatment and disposal of wastewaters and sludges.

\section{Pollutant Removal Mechanisms}

Removal of wastewater constituents is accomplished by physical, chemical, and biological processes with numerous and complex interactions occurring between these processes (Mercer et al. 1979). The physical process of filtration provides the removal mechanism for suspended particulate matter in the wastewater. Soil and root microorganisms are responsible for biological degradation of numerous wastewater constituents. Both organic and inorganic compounds are broken down and/or utilized for metabolism by these microorganisms. Chemical processes, such as precipitation, ion exchange, oxidation and reduction, may occur to remove many inorganic and some organic substances. Precipitation of heavy metals, for example, is primarily responsible for removal of these constituents by soil, although ion exchange may be a contributing factor. Land Application Methods

Existing 1 and treatment facilities can be classified according to two different basic design patterns based on differences in liquid loading rates, 1 and area requirements, and the interaction of the wastewater with vegetation and soil. The first method, infiltration, uses the entire soil column for purification while the second, overland flow, uses only the soil surface as the purification medium. Infiltration is further divided into two categories, irrigation and infiltration-percolation, which typically involve low and high rates of application, respectively.

Irrigation is the most common method of wastewater application. This is generally accomplished by sprinkler or spray methods. In areas where irrigation water is scarce, the system is managed to provide the maximum return from a crop, whereas in areas of sufficient water supply, criteria allowing maximum hydraulic loading are followed. Revenue realized from a crop is used to defray operating costs so deciding whether the system is to produce crops or treat effluent is important. Controlling soil salts is vital for plant growth to prevent buildup of toxic concentrations. This is accomplished by managing the wastewater salt concentrations and the rates of application. 
Suitability for Retort Water

Wastewater composition is one of the most important factors to be considered when investigating the applicability of 1 and treatment and disposal for a particular wastewater. The general criteria for judging the suitability of a wastewater for land disposal are given below:

1. The organic material must be biologically degradable at reasonable rates.

2. It must not contain materials in concentrations toxic to soil microorganisms. Since some toxic materials may accumulate through adsorption or ion exchange and approach toxic levels after prolonged operation, there must be reasonable assurance that this effect can either be prevented or mitigated.

3. It must not contain substances that will adversely affect the quality of the underlying ground water. In many instances, decisions relative to this aspect of land disposal systems are difficult because of the uncertain nature of available estimating techniques.

4. It must not contain substances that cause deleterious changes to the soil structure, especially its infiltration, percolation, and aeration characteristics. An imbalance of sodium ion relative to other cations is a common problem in this regard.

Characteristics relevent to 1 and disposal are presented for a number of different retort waters in Table 1. High salinity commonly found in the retort water would be toxic to most cover crops. Waters having conductivities greater than 2,250 $\mathrm{mmhos} / \mathrm{cm}$ are considered unsuitable for irrigation in most cases.

Substances which could affect ground water quality at a land disposal site receiving retort water are listed below:

- high salinity;

- high nitrogen concentrations which yield nitrate upon oxidation; and

- refractory organics which are not oxidized or removed by the soil.

The high salinity found in most retort waters would adversely affect drinking water quality if sufficient dilution were not available in the aquifer. A 
limit of $500 \mathrm{mg} / \mathrm{L}$ is recommended for drinking water and this value is exceeded by more than $100 \%$ for all the retort waters 1 isted in Table 1 , even after steam stripping for ammonia removal. Furthermore, evaporation of water during irrigation and leaching of salts from the soil will add to the dissolved solids content of the retort water as it percolates to the ground water.

Particular care must be exercised to control the application of nitrogen to the soil. Sufficient nitrogen must be available as a nutrient for growth of the cover crop; however, excessive loading of nitrogen would result in nitrate contamination of the ground water. Steam stripping can be used to control the concentration of ammonia, but other forms of nitrogen (nitrate and organic $-N$ ) may dictate the 1 and requirement to attain the desired nitrogen loading. The nitrate and organic -nitrogen content of retort water has not been determined on a sufficient number of samples to establish an average or range of values.

Steam stripping of ammonia is more effectively accomplished at high $\mathrm{pH}$ levels. Stripping efficiency is reduced as neutrality is approached and becomes low for acidic solutions. Additional alkalinity in the form of lime is frequently added to maintain adequate $\mathrm{pH}$ levels. The addition of lime in the stripping process substitutes $\mathrm{Ca}^{+2}$ ion for ammonia ion which is beneficial from the standpoint of the ratio of $\mathrm{Na}^{+}$to $\mathrm{Ca}^{+2}$ plus $\mathrm{Mg}^{+2}$. However, if considerable lime is required, the salinity of the steam stripped waste will be high due to the calcium salts present. Removal of all the ammonia may not be required since some nitrogen will be required for vegetation growth and oxidation of the organic matter in the retort water. In addition to ammonia, nitrogen can be supplied by organic-nitrogen and nitrate-nitrogen in the retort water.

The generally high ammonia levels in retort water would be expected to cause toxicity problems if not removed prior to disposal of the water to 1 and. Although removal of the ammonia may be relatively costly, part or all of this cost may be recovered by marketing the ammonia. It is likely that steam stripping would be used to remove the ammonia since this process is well adapted to removal of high concentrations of ammonia from wastewater. Steam stripping is the standard industrial process used for removal of amonia from coking liquors and petroleum refinery sour water. Sufficient alkalinity must be available in 
the retort water to allow conversion of $\mathrm{NH}_{4}^{+}$ion to volatile $\mathrm{NH}_{3}$ which is stripped by the steam passing counter-currently to the water in the stripping column.

It is possible that some of the organic constituents in retort water will be resistant to oxidation and might eventually be leached into the ground water causing some deterioration in the quality of the ground water. A low BOD relative to a $\operatorname{COD}$ could indicate a large fraction of the organic matter in the retort water is not readily biodegradable. Therefore, it is anticipated that low loading rates will be required to allow sufficient time for oxidation of the organics by the biota in the soil. The generally high organic content would appear to be the limiting factor on application rates of retort water to 1 and rather than hydraulic characteristics. Furthermore, refractory organics which would not degrade even under low loading rates could leach through to ground water.

Other toxic substances which may be found in retort water include specific ions and toxic organic compounds. Table 5 lists recommended limits for waters used up to 20 years on fine-textured soils of pH 6.0 to 8.5 at application rates of 37 and $99 \mathrm{~cm} /$ hectare/yr. These application rates are in the range of 25 to $99 \mathrm{~cm} /$ hectare/yr recommended for domestic wastes which are much 1 ower in organic matter than retort waters. It is likely that lower application rates would be used for high organic strength wastes such as retort water. Comparison of data in Table 5 with data in Tables 2 and 3 indicate that As, B (boron), $\mathrm{Cu}, \mathrm{F}, \mathrm{Mo}$, and $\mathrm{Zn}$ could potentially cause problems with land disposal of retort water. No data are available on the presence of organic substances which may cause problems.

Substances which cause plugging of the soil commonly include sodium ion (when it is unbalanced with $\mathrm{Ca}^{+2}$ and $\mathrm{Mg}^{+2}$ ) and suspended solids (nonbiodegradable). Suspended solids can plug the pores of the soil through the process of filtration, while sodium ion can cause dispersal of the clay particles in the soil thus sealing the pore structure. Currently, data are insufficient to evaluate the possible effect of suspended solids in retort water on land disposal, but at least part of the suspended matter in retort water is expected to be removed in the pretreatment steps for ammonia stripping to avoid fouling 
TABLE 5. Recommended Limits of Specific Ions in Irrigation Water

\begin{tabular}{|c|c|c|}
\hline Element & $\begin{array}{l}\text { Application } \\
3 \mathrm{ft} / \mathrm{yr} \text { Application } \\
\text { Recommended Limit }(\mathrm{a}) \\
\end{array}$ & $\begin{array}{l}\text { nits, mg/L } \\
8 \mathrm{ft} / \mathrm{yr} \text { Application } \\
\text { Estimated Limit } \\
\end{array}$ \\
\hline A1 & 20.0 & 8.0 \\
\hline As & 2.0 & 0.8 \\
\hline $\mathrm{Be}$ & 0.50 & 0.2 \\
\hline B & $2.0-10.0$ & 2.0 \\
\hline $\mathrm{Cd}$ & 0.050 & 0.02 \\
\hline $\mathrm{Cr}$ & 1.0 & 0.4 \\
\hline Co & 5.0 & 2.0 \\
\hline $\mathrm{Cu}$ & 5.0 & 2.0 \\
\hline $\mathrm{F}$ & 15.0 & 6.0 \\
\hline $\mathrm{Fe}$ & 20.0 & 8.0 \\
\hline $\mathrm{Pb}$ & 10.0 & 4.0 \\
\hline $\mathrm{Li}$ & 2.5 & $2.5^{(b)}$ \\
\hline$M n$ & 10.0 & 4.0 \\
\hline $\mathrm{Hg}$ & --- & -- \\
\hline Mo & $0.050^{(c)}$ & $0.02^{(c)}$ \\
\hline $\mathrm{Ni}$ & 2.0 & 0.8 \\
\hline Se & 0.020 & 0.02 \\
\hline $\mathrm{Ag}$ & --- & -- \\
\hline $\mathrm{Zn}$ & 10.0 & 4.0 \\
\hline
\end{tabular}

(a) EPA Water Quality Criteria, 1972.

(b) Recommended maximum for citrus crops is $0.075 \mathrm{mg} / \mathrm{L}$.

(c) Only for acid fine textured soils or acid soils with relatively high iron oxide contents.

the stripping column. Air pollution from volatile organic constituents in this waste is also a potential problem. Retort water generally has an offensive odor which would not be well received by downwind recipients from the disposal site. Consideration would also have to be given to the possible presence of volatile toxic organics or other organics which would degrade air quality in the region. 
Effect of Climate

The long winters characteristic of the $0 i 1$ shale regions of Colorado, Utah, and Wyoming adversely affect the cost of 1 and disposal by irrigation and over land runoff due to the 1 arge wastewater storage requirement. Irrigation and overland runoff are not possible during extended periods of freezing temperatures and application rates must be reduced during cool weather. Based on the length of frost free seasons, storage requirements range from 5 to 10 months, however, specific site operations may decrease the storage area needed.

\section{UNDERGROUND INJECTION}

Underground or deep well injection is a disposal method which seeks to isolate a liquid waste in a geologic strata to eliminate, as nearly as possible, any environmental impacts resulting from disposal of the waste. Geologic strata selected to receive wastes by this method are generally located at a considerable distance from ground surface to provide additional assurance of confinement and avoid contaminating freshwater aquifers near the surface. Underground injection is normally reserved for wastewaters which are very difficult or expensive to treat for release to surface receiving waters. It is used extensively for the disposal of $0 i 1$ well brine wastes.

\section{EPA Regulations}

In December 1974, the National Safe Drinking Water Act (Public Law 93-523) was passed by Congress. The purpose of this legislation was to assure that water supply systems meet minimum national standards for the protection of public health. The Act was designed to achieve uniform safety and quality of

drinking water in the nation by identifying contaminants and establishing maximum levels of contaminant concentration in drinking water. The major provision of the Act that encompasses the underground injection program is the establishment of regulations to protect the underground drinking water sources by the control of subsurface injection of fluids including wastes. Rules pertaining to the administration of the underground injection control (UIC) program were issued in 1980 as part of the consolidated permit program 40 CFR Parts 122 , 
123, and 124. Technical criteria and standards (40 CFR Part 146) for the UIC program were also issued in 1980. The States were given the options of:

1) administering their own UIC program upon approval of the EPA or

2) allowing the EPA to do it.

The UIC permit program established by the EPA regulates underground injection by five classes of wells:

Class I. Wells used by generators of hazardous wastes or operators of hazardous wastes management facilities or other industrial and municipal entities which inject fluids beneath the lowermost formation containing an underground source of drinking water within one-quarter mile of the well bore.

Class II. Wells used to inject fluids in connection with gas and oil recovery or storage operations.

Class III. Wells used in connection with recovery of minerals or energy.

Class IV. Wells used to inject hazardous or radioactive wastes into or above a formation that has a drinking water source within onequarter mile of the well bore.

Class V. Injection wells not included in Classes I, II, III and IV.

Class IV wells which inject hazardous wastes directly into an underground drinking water source are to be phased out and no permits will be issued for new wells in this class.

Disposal wells that do not discharge wastes within one-quarter mile of a drinking water source are included under $\mathrm{Cl}$ ass $\mathrm{V}$. At the date of this writing $C l$ ass $V$ wells are being inventoried and assessed but regulatory action is to be taken at a later date. However, no Class $V$ well will be authorized by permit or rule if it results in the presence of any contaminant in an underground source of drinking water which may adversely affect human health. 
EPA construction, operating, and monitoring criteria and standards applicable to Class I wells (40 CFR Part 146) are given below:

\section{A. Construction Requirements}

1. All Class I wells shall be sited in such a fashion that they inject into a formation which is beneath the lowermost formation containing, within one-quarter mile of the well bore, an underground source of drinking water.

2. All Class I wells shall be cased and cemented to prevent the movement of fluids into or between underground sources of drinking water. The casing and cement used in the construction of each newly drilled well shall be designed for the life expectancy of the well.

3. All Class I injection wells, except those municipal wells injecting noncorrosive wastes, shall inject fluids through tubing with a packer set immediately above the injection zone, or tubing with an approved fluid seal as an alternative. The tubing, packer, and fluid seal shall be designed for the expected service.

The use of other alternatives to a packer may be allowed with the written approval of the Director of the authorized regulatory agency. To obtain approval, the operator shall submit a written request to the Director, which shall set forth the proposed alternative and all technical data supporting its use. The Director shall approve the request if the alternative method will reliably provide a comparable level of protection to underground sources of drinking water. The Director may approve an alternative method solely for an individual well or for general use.

B. Operating Requirements

1. Except during stimulation, injection pressure at the wellhead shall not exceed a maximum which shall be calculated so as to assure that the pressure in the injection zone during injection 
does not initiate new fractures or propagate existing fractures in the injection zone. In no case shall injection pressure initiate fractures in the confining zone or cause the movement of injection or formation fluids into an underground source of drinking water.

2. Injection between the outermost casing protecting underground sources of drinking water and the well bore is prohibited.

3. Unless an alternative to a packer has been approved, the annulus between the tubing and the long string of casing shall be filled with an approved fluid maintained at an approved pressure.

C. Monitoring Requirements

Monitoring requirements shall, at a minimum, include:

1. The analysis of the injected fluids with sufficient frequency to yield representative data of their characteristics;

2. Installation and use of continuous recording devices to monitor injection pressure, flow rate and volume, and the pressure on the annulus between the tubing and the long string of casing;

3. A demonstration of mechanical integrity once every five years during the life of the well; and

4. The type, number and location of wells within the area of review to be used to monitor any migration of fluids into underground sources of drinking water, the parameters to be measured and the frequency of monitoring.

\section{Wastewater Quality Requirements for Injection}

The suitability of waste for underground injection depends on its volume and physical and chemical characteristics, and on the physical and chemical properties of the potential injection zones and their interstitial fluids. Wastewater that is desirable for injection must be: 1) low in volume and high in concentration, 2) difficult to treat by surface methods, 3) free of any adverse reaction with the formation fluid or the strata, 4) free of suspended 
solids, 5) biologically inactive, and 6) noncorrosive. Underground injection was evaluated for shale oil wastewater by Mercer et al. (1979).

Waste disposal into underground aquifers constitutes the use of limited storage space, and only concentrated, very objectionable, relatively untreatable wastes should be considered for injection. The fluids injected into deep aquifers do not occupy empty pores, but displace the fluids which saturate the storage zone. The displaced fluids are frequently polluted (e.g., high salinity) and may migrate to fresh water aquifers. Consequently, optimal use of the underground storage space will be realized by the use of underground injection only when more satisfactory alternative methods of waste treatment and disposal are not available.

Reaction of the wastewater with the formation water or the strata is important. Resulting problems could include dissolving the formation, generating a gas or precipitate in the formation, and clogging by biological growths. Walker and Stewart (1968) suggest a laboratory test to ensure compatibility of the wastewater with the formation. The wastewater can be mixed in a beaker with a formation water sample and held at formation temperature to see if there is any precipitate or adverse reaction. Pumping the wastewater through a core sample can reveal possible clogging problems. The wastewater should be free of suspended solids and biologically inactive to avoid reservoir clogging. The corrosiveness of the wastewater should be low to prevent tubing and pump corrosion.

Disposal Site Selection

Great care must be exercised in the selection of an underground disposal site for liquid wastes. The suitability of a specific location of a waste injection well must be evaluated by a detailed geological subsurface investigation. However, regional geological conditions can be used to evaluate general suitability of certain areas.

The regional favorability map (Figure 1) indicates that certain areas of the continental United States, such as the Rocky Mountains, are generally unsuitable for waste injection wells because igneous or metamorphic rocks lie 


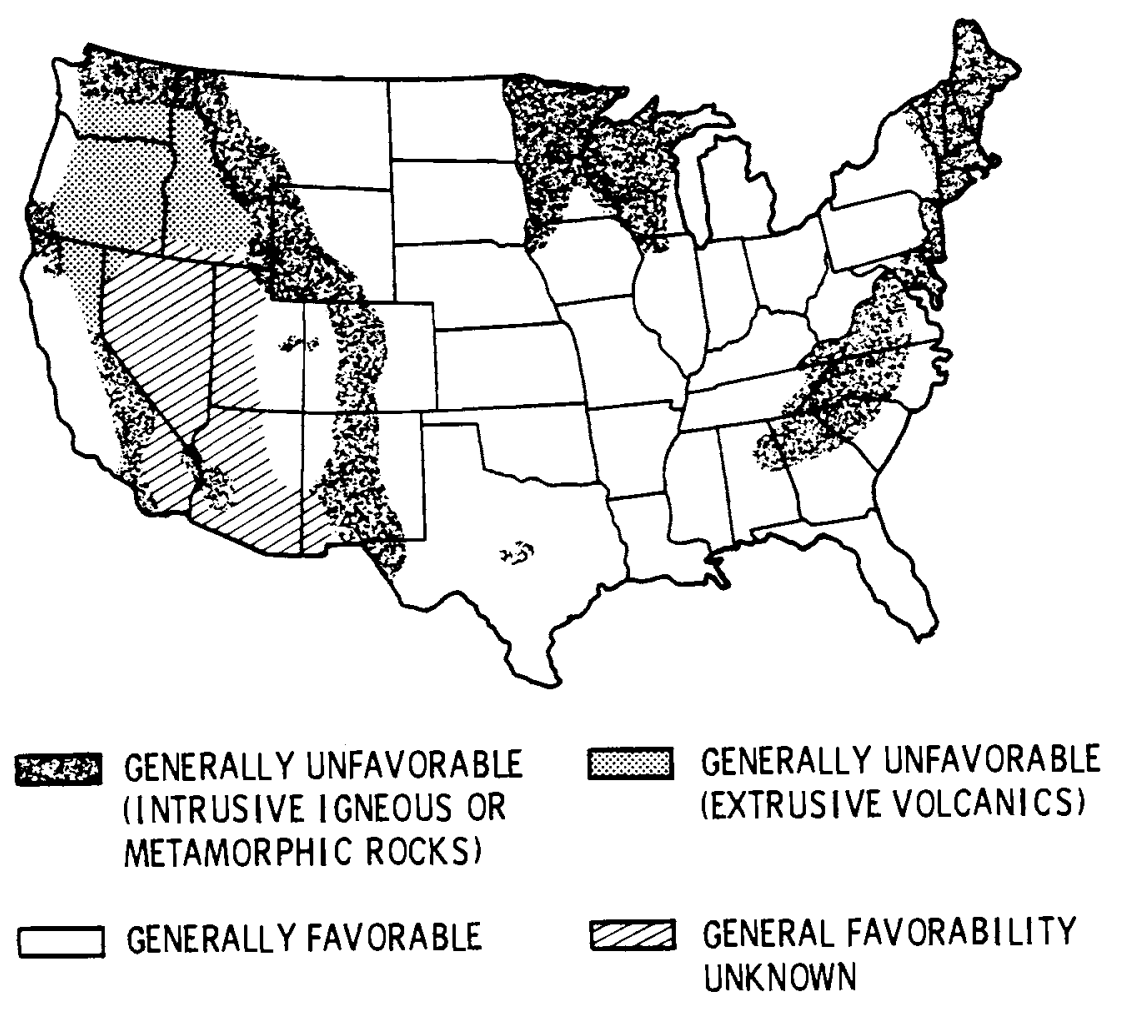

FIGURE 1. Deep Well Disposal Sites

at or near the ground surface. Such rocks do not have sufficiently high porosity or permeability to warrant their use as a disposal formation. Areas with extensive extrusive volcanic sequences exposed are also not suitable for waste disposal wells. Even though these rocks have porous zones, they usually contain freshwater. The waste disposal potentials of the Basin and Range Provinces (see angled lines on map) are largely unknown because the geologic conditions are complex.

The final appraisal of a disposal well site is usually determined by a two-phase geologic investigation. The first phase includes an evaluation of potential sites on the basis of available data. The second phase consists of a more detailed evaluation of subsurface conditions based on information obtained from drilling a pilot hole or the injection well. Suitability of Retort Water for Underground Injection

The suitability of retort water for underground injection depends on its volume and physical and chemical characteristics and on the physical and 
chemical properties of potential injection zones and their interstitial fluids. Disposal of small volumes of retort water by underground injection would stand a better chance of acceptance by regulatory agencies than disposal of large volumes. Removal of suspended solids from retort water is very important to prevent plugging of the injection zone but very little information is available on clarification of these wastewaters. Chemical reactions of retort water with the injection zone are possible (e.g., reaction of $\mathrm{Ca}^{+2}$ in interstitial water with $\mathrm{CO}_{3}$ retort water to form $\mathrm{CaCO}_{3}$ which would plug the receiving formation).

\section{STEAM STRIPPING}

Steam stripping is a standard industrial process used for removing ammonia and hydrogen sulfide from refinery sour water and ammonia from coking liquors. It is anticipated that steam stripping will be required either as a pretreatment step for other processes or by itself prior to reuse applications such as dust control or moisturizing spent shale. Bench-scale treatability studies were conducted to evaluate the application of this process to retort water (Mercer et al. 1982).

\section{Process Description}

Steam stripping can be considered a form of gas stripping where water vapor at elevated temperature is used as the medium for transfer and removal of volatile constituents from a liquid. Steam stripping is generally carried out in a continuous operation with a tower equipped with trays (e.g., bubble cap or sieve) or a suitable packing (e.g., saddles or rings) which enhances the contact of the gaseous phase with the liquid phase.

A typical steam stripper design is illustrated in Figure 2. The preheated wastewater is introduced at the top of the tower and flows by gravity countercurrent to the steam which is flowing up from the bottom of the tower. As the liquid flows down the tower it contacts steam containing progressively lower concentrations of volatile constituents stripped from the liquid. At the same time, the volatile constituents in the liquid are reduced to lower concentrations as the liquid flows to the bottom of the tower. The concentration of the volatile constituents is reduced to the lowest value at the bottom of the 


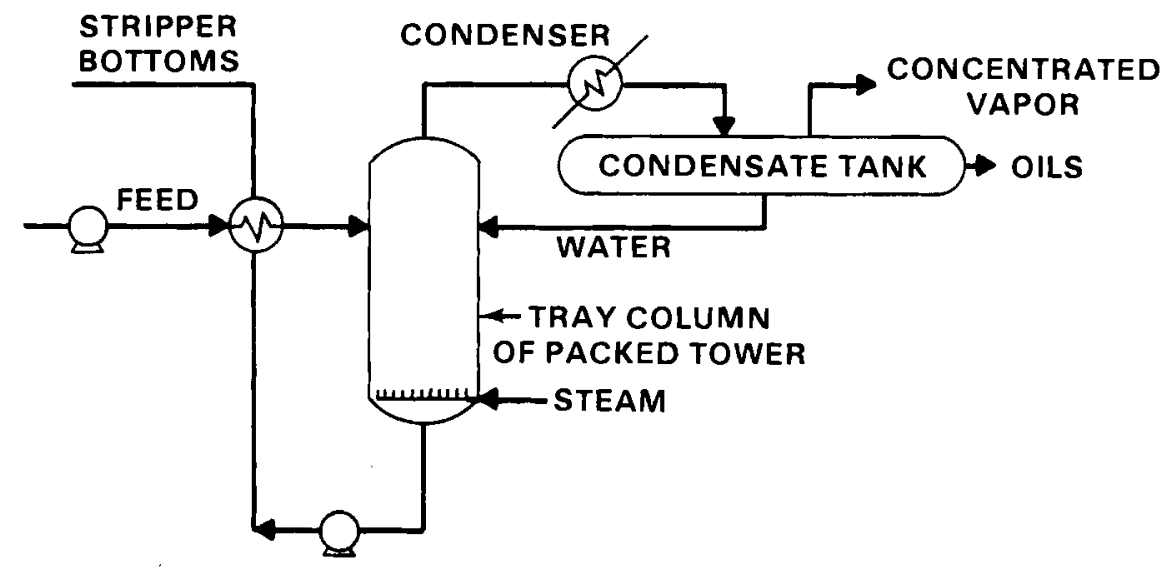

FIGURE 2. Typical Steam Stripping System

tower, where the liquid is first contacted by the incoming steam. Heat conservation is practiced by preheating the feed with the stripped bottoms in a heat exchanger.

Steam from the top of the tower may either be condensed or it may be further processed in the gaseous phase (e.g., incinerated) before discharge. Condensation of the steam and organic vapors may produce an aqueous phase and an organic phase (e.g., water immiscible organics) which can be separated by decantation. Noncondensable vapor and gases may receive further treatment or be released to the atmosphere if pollutant levels are low. Recycle or reflux of the condensate stream to the tower serves to increase the concentration of volatile constituents in the effluent steam from the tower and also eliminates a secondary wastewater stream which might require treatment before release.

\section{Bench-Scale Treatability Studies}

Bench-scale studies were performed to evaluate steam stripping as a means of removing ammonia from retort water (Mercer et a1. 1982). The steam stripper used in this work consists of $5 \mathrm{~cm}$ ID glass pipe packed to a depth of $120 \mathrm{~cm}$ with either 1.27 or $0.635 \mathrm{~cm}$ Intalox ${ }^{\circledR}$ ceramic saddles. Feed to the stripper is introduced at the top of the column of saddles and is counter-currently

$\bar{Q}$ Trademark of Norton Company. 
contacted with steam generated by a reboiler at the bottom of the column. Steam containing volatile constituents stripped from the feed is removed from the top of the column, condensed, and collected in a condensate receiver. The condensate receiver is vented to two water traps in series to adsorb ammonia vapor carried over with noncondensable gases. The condensate may be recycled by injecting it into the feed stream to the stripping column. The alternative of no condensate recycle results in an aqueous ammonia solution which contains volatile organics stripped from the retort water. The steam-stripper feed collects in the reboiler and is withdrawn continuously to maintain a constant level in the reboiler.

Tests were made with several different process waters. The results are presented in Table 6 . The major difference between the two runs made with simulated in situ process water is the addition of $\mathrm{NaOH}$ in the case where condensate was recycled. This accounts for the higher effluent $\mathrm{pH}$ which is critical to maintaining ammonia as free $\mathrm{NH}_{3}$. Without the $\mathrm{NaOH}$ addition, the performance with recycle and lower boiloff rate would have given ammonia removal levels below $98 \%$. With the alkalinity addition, it was possible to achieve $99.95 \%$ removal.

Stripping data in Table 6 for Geokinetics No. 2 shows the effect of recycle of the condensate at low boiloff rates. Ammonia removal was only $83 \%$ with recycle at a boiloff rate of $5 \%$. Changing the packing to a smaller size as in Geokinetics No. 3 appeared to increase the ammonia removal at a boiloff rate of $5 \%$. Additional factors which may have contributed to the higher ammonia removal rate are the lower flow rate and a different composition of process water, although the primary controlling factor of $\mathrm{pH}$ was essentially the same for each wastewater. The stripper performance for Geokinetics No. 4 was much improved over No. 3. This improvement was apparently due to small increases in the boiloff rate and $\mathrm{pH}$. The $\mathrm{pH}$ from feed to effluent increased due to the stripping of $\mathrm{CO}_{2}$ from the $\mathrm{NaHCO}_{3}$ present in Geokinetics process water. Ammonia removal for the Paraho retort water was very poor without $\mathrm{NaOH}$ addition since most of the ammonia is in the fixed form $\mathrm{NH}_{4}^{+}$without sufficient carbonate alkalinity. 
TABLE 6. Steam Stripping Results

Stripper

\begin{tabular}{|c|c|c|c|c|c|c|}
\hline $\begin{array}{l}\text { Run } \\
\text { No } \\
\end{array}$ & Retort Water & $\begin{array}{c}\text { Packing } \\
\text { Diameter, (a) } \\
\mathrm{cm} \\
\end{array}$ & $\begin{array}{l}\text { Feed } \\
\text { Rate, } \\
\mathrm{ml} / \mathrm{min} \\
\end{array}$ & $\begin{array}{l}\text { Boil off } \\
\text { Rate, } \\
\% \\
\end{array}$ & $\begin{array}{l}\text { Condensate } \\
\text { Recycle } \\
\end{array}$ & $\begin{array}{l}\mathrm{NaOH} \\
\text { Added, } \mathrm{g} / \mathrm{L} \\
\end{array}$ \\
\hline 1 & Simulated in situ & 0.64 & 55 & 14 & No & 0 \\
\hline 2 & Simulated in situ & 0.64 & 45 & 11 & Yes & $\cdot 2$ \\
\hline 3 & Geokinetics No. 2 & 1.28 & 100 & 8 & No & 0 \\
\hline 4 & Geokinetics No. 2 & 1.28 & 110 & 5 & Yes & 0 \\
\hline 5 & Geokinetics No. 3 & 0.64 & 57 & 5 & Yes & 0 \\
\hline 6 & Geokinetics No. 4 & 0.64 & 51 & 6 & Yes & 0 \\
\hline 7 & Paraho & 0.64 & 27 & 30 & Yes & 0 \\
\hline 8 & Paraho & 0.64 & 56 & 20 & No & 73 \\
\hline 9 & Paraho & 0.64 & 33 & 11 & No & 73 \\
\hline 10 & Paraho & 0.64 & 22 & 11 & No & 90 \\
\hline
\end{tabular}

TOC

Run
No Retort Water

1 Simulated in situ

2 Simulated in situ

3 Geokinetics No. 2

4 Geokinetics No. 2

5 Geokinetics No. 3

6 Geokinetics No. 4

7 Paraho

8 Paraho

9 Paraho

10 Paraho
Influent Effluent

$\mathrm{pH}$

9.4

9.5

8.8

8.8

8.7

8.6

8.5

10.5

10.6

11.6
$\mathrm{pH}$

\section{9}

10.2

9.7

9.7

9.6

10.0

6.2

7.6

8.2

10.6

\begin{tabular}{l} 
Inf 1uent \\
TOC, $\mathrm{g} / \mathrm{L}$ \\
\hline 2.0 \\
2.0 \\
-- \\
-- \\
1.0 \\
1.8 \\
45 \\
45 \\
45 \\
45
\end{tabular}

45

\section{TOC} Removal, -

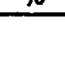

$--$

18

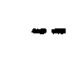

$--$

19

17

--

2.0

5.7

2.2
Influent $\mathrm{NH}_{3}, \mathrm{~g} / \mathrm{L}$

28 28

\section{$3.3 \quad 99.5$}

3.383

$1.0 \quad 96$

2.199 .5

$30 \quad 38$

$30 \quad 90$

30

89

99

(a) Intalox saddles

(b) Percent of feed 
A series of three runs were made with Paraho retort water wherein $\mathrm{NaOH}$ was added to improve ammonia removal. The results of these runs (Nos. 8, 9, and 10 in Table 6) show ammonia removal increased to $89-90 \%$ with $73 \mathrm{~g} / \mathrm{L} \mathrm{NaOH}$ addition and to $99 \%$ with $90 \mathrm{~g} / \mathrm{L} \mathrm{NaOH}$ additions. The high $\mathrm{pH}$ of the stripper effluent in Run No. 10 indicates ammonia was maintained largely in its volatile, un-ionized form $\left(\mathrm{NH}_{3}\right)$ throughout the stripping column. Organic removal was less for Paraho retort water compared to Geokinetics and simulated in situ retort water.

The addition of lime, $\mathrm{Ca}(\mathrm{OH})_{2}$, would be less costly than $\mathrm{NaOH}$ however this would create a large amount of calcium carbonate sludge. The formation of this sludge can be avoided and lime usage minimized by removing the free ammonia first in a separate stripper or stripper section (which also removes $\mathrm{CO}_{2}$ ), then adding lime to remove the fixed ammonia. Ammonia stripping is accomplished on coking liquor in this manner.

Some fouling of the packing in the stripping column was observed in the case of Geokinetics retort water, which may have been the result of suspended matter depositing on the packing. Although settled retort water was used, it contained about $150 \mathrm{mg} / \mathrm{L}$ of suspended solids, which was reduced to about $30 \mathrm{mg} / \mathrm{L}$ through the stripper. The use of trays instead of packing may be required in a full-scale steam stripper to minimize fouling problems. A small volume of light oil was also removed by the steam stripping operation. Organic carbon removal by steam stripping determined for three runs ranged from 17 to 19\%. A $70 \%$ reduction in total alkalinity was measured in one test of the stripper. Problems with foaming were experienced with the operation of the reboiler on the bench-scale steamer stripper. Maintaining a low liquid level in the reboiler or addition of an antifoaming agent was necessary to prevent foam from entering and flooding the stripping column.

Removal of Alkylpyridines

Study Objective

Disposal of large volumes of retorted shale to canyons could lead over time to contamination of adjacent soils, surface waters and ground waters as a result of leaching of organic components associated with the retorted shale. 
The leaching of organic constituents from retorted shale piles could be significantly increased with codisposal of retort water. Waste treatment has been proposed as a means of reducing the concentrations of the organic components in retort waters prior to codisposal if the waters were to be used for shale pile compaction and dust control. Samples of influent and effluent streams from steam stripping of retort water were therefore analyzed to characterize those organic components retained or removed by this process. Emphasis was placed on the ability of this process to efficiently remove alkylpyridines from the water since this group of compounds was found to be mobile in soils (Zachara et al. 1981) and found present in subsoils, surface waters and ground waters as a result of operations at the Department of Energy's Anvil Points 0 il Shale Facility, Rifle, Colorado (Riley et al. 1981).

\section{Analytical Methodology}

Samples $(50 \mathrm{ml})$ from the steam-stripping experiment were adjusted to $\mathrm{pH} 12$

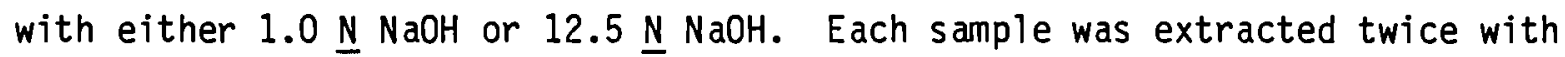
methylene chloride $(1 \times 10 \mathrm{ml} ; 1 \times 5 \mathrm{ml})$. The methylene chloride extracts were combined and concentrated to a volume of $1 \mathrm{ml}$. Internal standard was added (hexamethylbenzene) and the samples were analyzed for alkylpyridines by capillary gas chromatography.

Standard mixtures and samples of feed (Run 10 Table 6), effluent and condensate from the steam-stripping experiment were extracted and subjected to analysis on a Hewlett-Packard 5985 GC/MS system operating in the electron impact mode and coupled to a 5840A gas chromatograph equipped with capillary column (50 m fused silica) and operating in the splitless mode. For each sample run, the gas chromatograph was programmed from $70^{\circ}$ to $260^{\circ}$ at $3 \% / \mathrm{min}$. Scanning range for the collection of spectra was from 20 to 205 AMU.

A standard mixture of pyridines (pyridine, 4-methylpyridine, 2, 5-dimethylpyridine, 2, 4, 6-trimethylpyridine and t-butylpyridine) was added to water which had been $\mathrm{pH}$ adjusted to simulate the $\mathrm{pH}$ of retort water. Triplicate samples were extracted twice with methylene chloride $(2 \times 5 \mathrm{ml})$. The organic extracts were combined, concentrated and analyzed by capillary gas chromatography. Recovery of the individual components into methylene chloride 
was $98 \%$ for pyridine, $106 \%$ for 4-methylpyridine, $99 \%$ for 2, 5-dimethylpyridine, $102 \%$ for 2, 4, 6-trimethylpyridine, and $105 \%$ for t-butylpyridine.

Experimental Results. Samples of the feed condensate and effluent from Run 10 (Table 6) were analyzed by gas chromatography/mass spectrometry to obtain information on the distributions of organic components in each sample. Figure 3 depicts the total ion mass chromatograms for samples of the feed, condensate and the effluent and selected individual components positively identified in these fractions. Qualitative inspection of each chromatogram showed there to be several differences in the chemical composition of the condensate and effluent relative to the starting feed material. These differences could be broken down into three component regions: Region $A$ consisted of the most volatile organic components several of which efficiently partitioned to the condensate while others distributed themselves between both the condensate and the effluent. Regions $B$ and $C$ consisted of components that did not partition to the condensate from the feed. In Region $A$, a selection of components that appear to partition completely to the condensate are located at retention times (RT) of 13.5, 13.9, 14.3,14.9,16.1,18.9,19.1, 19.5, 22.0, 23.3, and $26.8 \mathrm{~min}$. Three compounds in this group were identified as a $\mathrm{C}_{2}$-pyridine (RT-13.5, Figure 4), $C_{3}$-pyridine (RT-16.1, Figure 5) and a $C_{4}$-pyridine (RT23.3, Figure 6), respectively. These data were supported by quantitative GC analysis of the distributions of a select group of alkylpyridines in samples derived from the same experiment (Table 7). During Run 10, $82 \%$ of the alkylpyridines measured in the feed (influent) were recovered in the steam stripped effluent and the condensate. $94 \%$ of the recovered alkylpyridines were contained in the condensate with the remaining $6 \%$ associaced with the steam stripped effluent. Only trace levels of pyridines were detected in the traps.

Thus it appears that this class of compounds can be effectively removed from retort water by steam stripping prior to possible codisposal of the water with retorted shale. Other components comprising Region $A$ of the effluent and condensate appear to be alkylated-substituted cyclohexenones and/or furans with molecular weights of 110 (RT $=13.5,15.6,15.9,16.8,17.7$, and $19.3 \mathrm{~min}$ ), $124(\mathrm{RT}=13.6,14.5,15.8,18.1$ and $20.1 \mathrm{~min})$ and $138(\mathrm{RT}=22.0 \mathrm{~min})$. The 

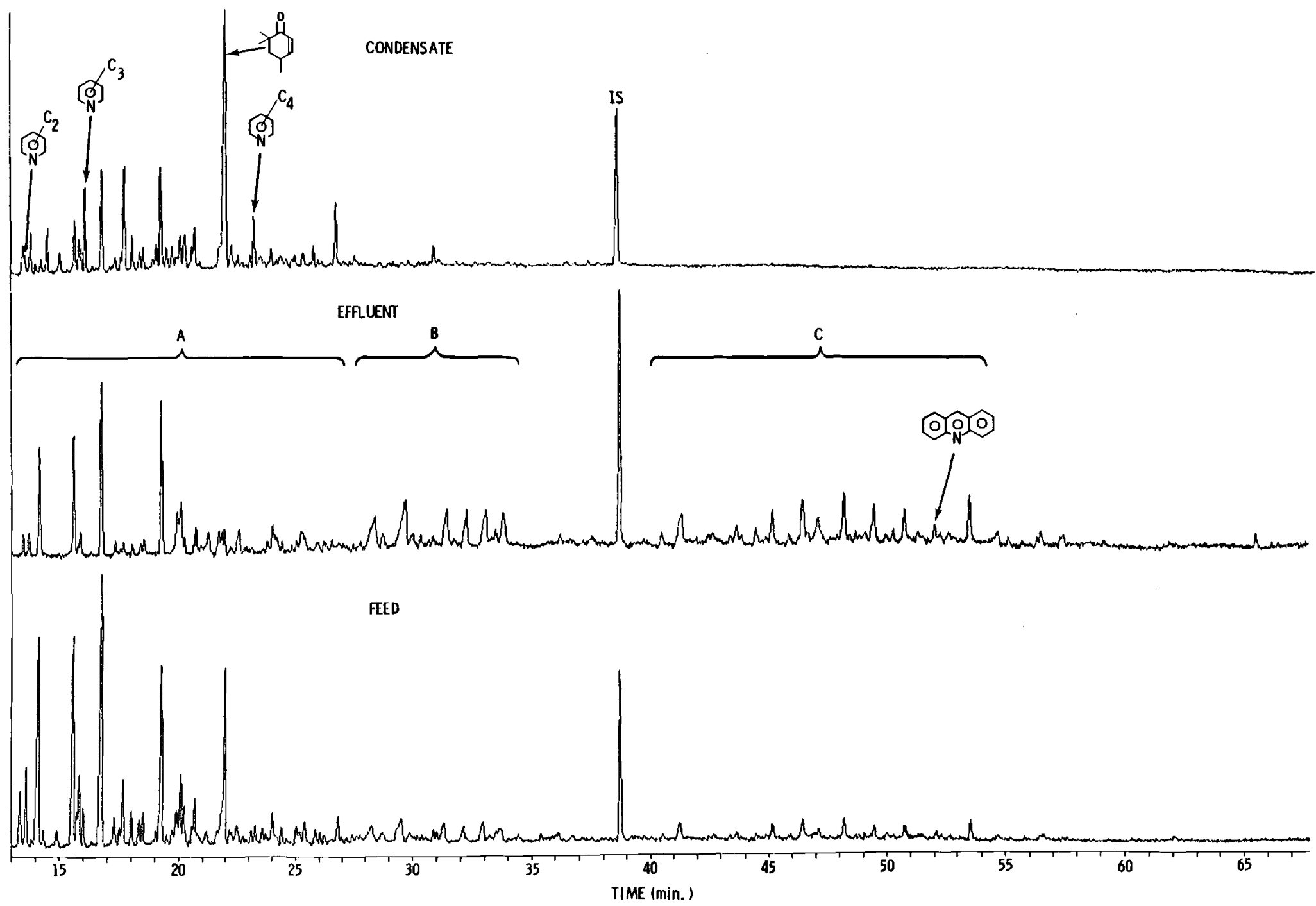

FIGURE 3. Tota 1 Ion Mass Chromatogram of Components in Solvent Extracts of Condensate, Effluent and Feed. Component fractions include $(A)$ those compounds that partition efficiently to the condensate (i.e., alkylpyridines) or those that distribute between the condensate and the effluent and ( $B$ and $C$ ) those compounds that are retained in the effluent. IS = hexamethylbenzene internal standard. 


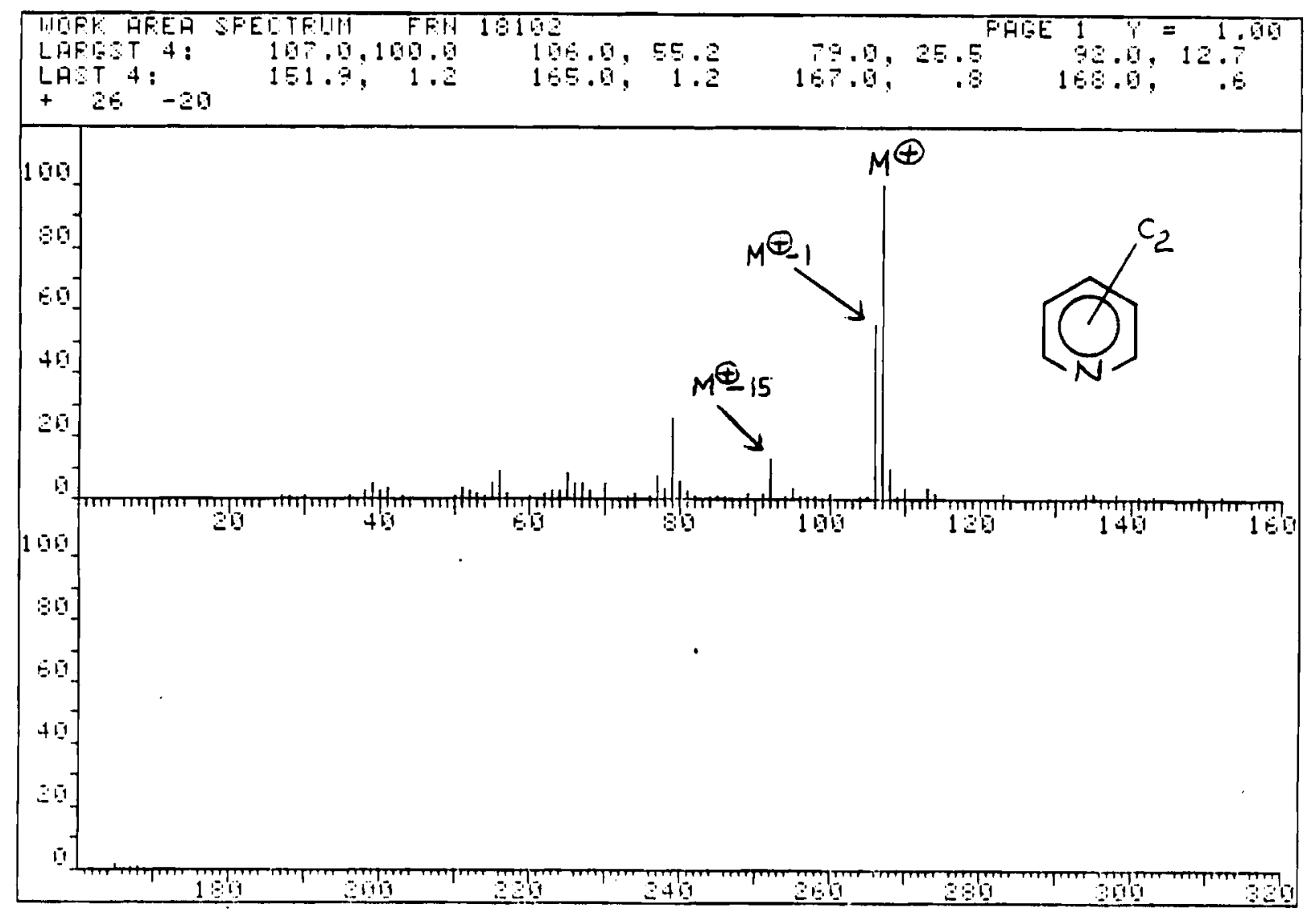

FIGURE 4. Mass Spectrum of $C_{2}$-Pyridine $(R T=13.5 \mathrm{~min})$

major component at RT $=22.0 \mathrm{~min}$, which efficiently partitioned to the condensate, had a mass spectrum which matched quite closely with the mass spectrum of $3,5,5$-trimethy-2-cyclohexen-1-one (Figure 7 ).

Components in Region B appeared to have molecular weights of 125 and 149 . The fact that the molecular weights were odd and differed by 14 units suggests the presence of alkyl-substituted components containing a nitrogen atom. Also retained in the effluent were those components in Region C. Major components in this region appeared to belong to a homologous series of alkylated components with molecular weights of $146(R T=43.7), 160(R T=44.6,45.2,46.5)$, $174(R T=48.2,49.5,50.3,50.8)$ and $188(R T=53.6)$. Gas chromatographic analysis of this effluent employing a nitrogen-specific detector showed the presence of nitrogen-containing components in this region which would suggest 


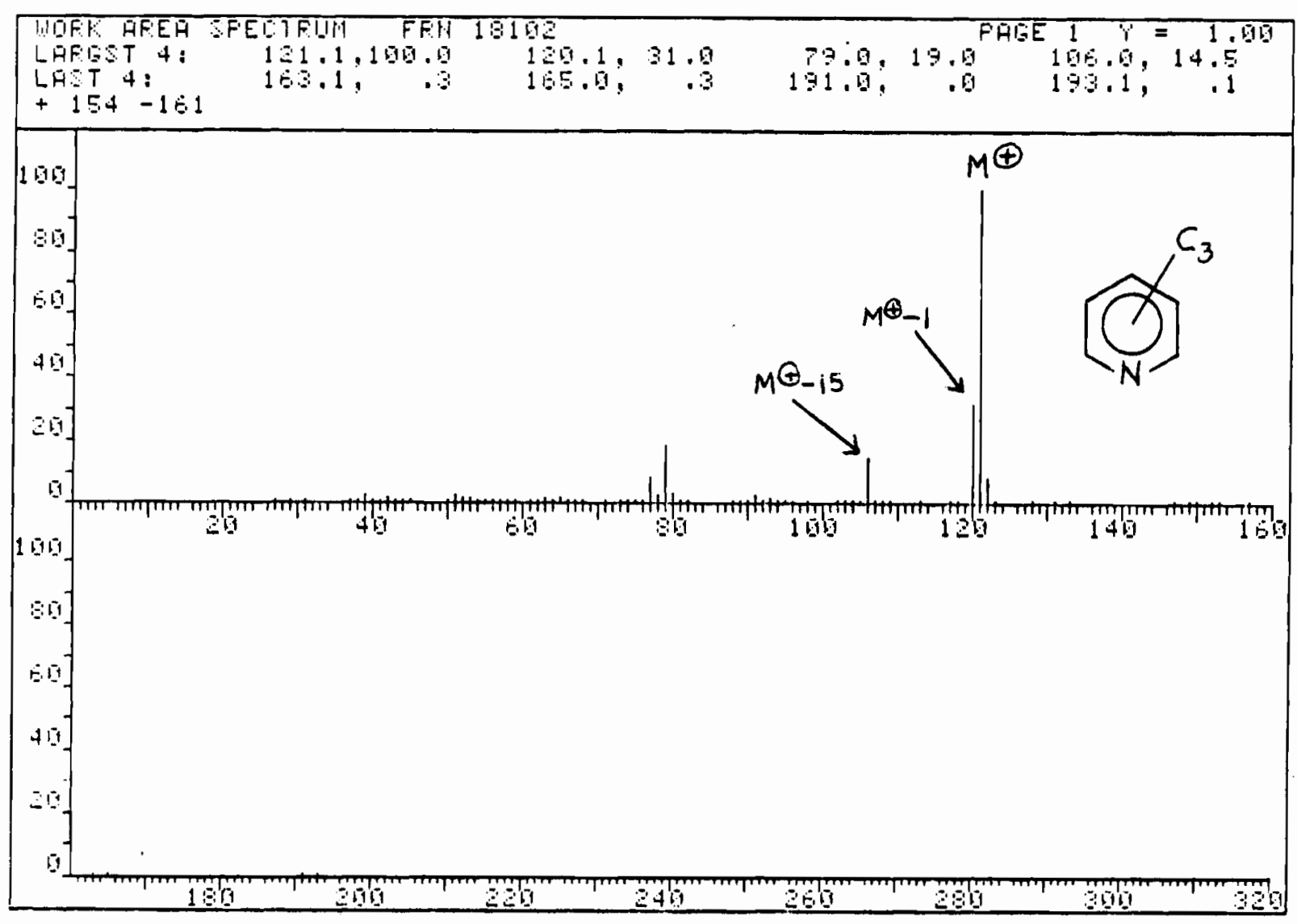

FIGURE 5. Mass Spectrum of $C_{3}$-Pyridine (RT $=16.1 \mathrm{~min}$ )

that these components may contain two nitrogen atoms. Comparison with known spectra suggest alkyl-substituted benzimidazoles as likely candidates although the non-nitrogen-containing alkyl benzofurans are a possibility. Also within this region, the component at a retention time of 52.1 nin has been tentatively identified as the nitrogen-containing heterocycle, acridine (Figure 8 ).

Based on the results of these waste treatment studies, steam stripping appears to be an efficient process for removing alkylpyridines and other volatile constituents from oil shale retort waters. However, the effluent from the steam stripping experiment contained less volatile components which may still make this water undesirable for disposal to retorted shale piles without additional treatment. Additional research is needed to: 1) identify these components; and 2) define their transport and fate in the environment. Based 


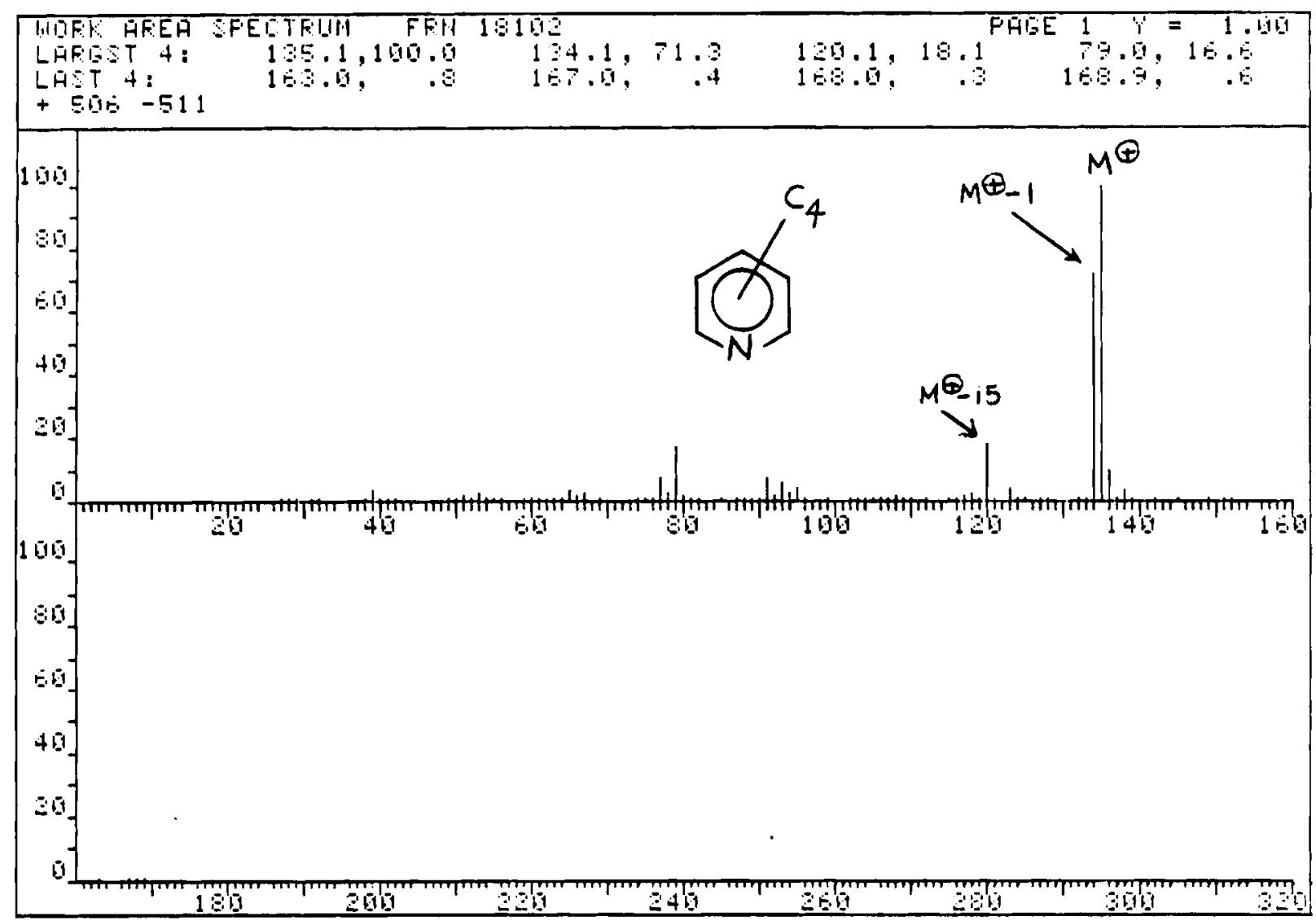

FIGURE 6. Mass Spectrum of $C_{4}$-Pyridine (RT $=23.3 \mathrm{~min}$ )

TABLE 7. Amounts and Distribution (\%) of Alkylpyridines in Samples Collected from Run 10 Steam Stripping Experiment

Sample Type (Amounts in $\mathrm{mg}$ )

\begin{tabular}{|c|c|c|c|c|c|}
\hline Compound Type & Feed & $\begin{array}{l}\text { Stripped } \\
\text { Effluent }\end{array}$ & Condensate & Trap 1 & Trap 2 \\
\hline$C_{1}$-Pyridine & 7 & 0.88 & 22 & 0.03 & 0.09 \\
\hline$C_{2}^{\perp}$-Pyridine & 34 & 0.66 & 38 & 0.15 & 0.03 \\
\hline$C_{3}$-Pyridine & 74 & 0.53 & 67 & 0.16 & 0.02 \\
\hline$C_{4}$-Pyridine & 58 & 0.53 & 40 & 0.04 & 0.02 \\
\hline$C_{5}$-Pyridine & 113 & 13 & 53 & 0.05 & 0.02 \\
\hline $\begin{array}{l}C_{6} \text {-Pyridine } \\
\text { Total Selected }\end{array}$ & 22 & 3 & 17 & 0.02 & 0.02 \\
\hline Pyridines & 308 & $16(6)$ & $237(94)$ & $0.4(0.1)$ & $0.09(0.03)$ \\
\hline
\end{tabular}




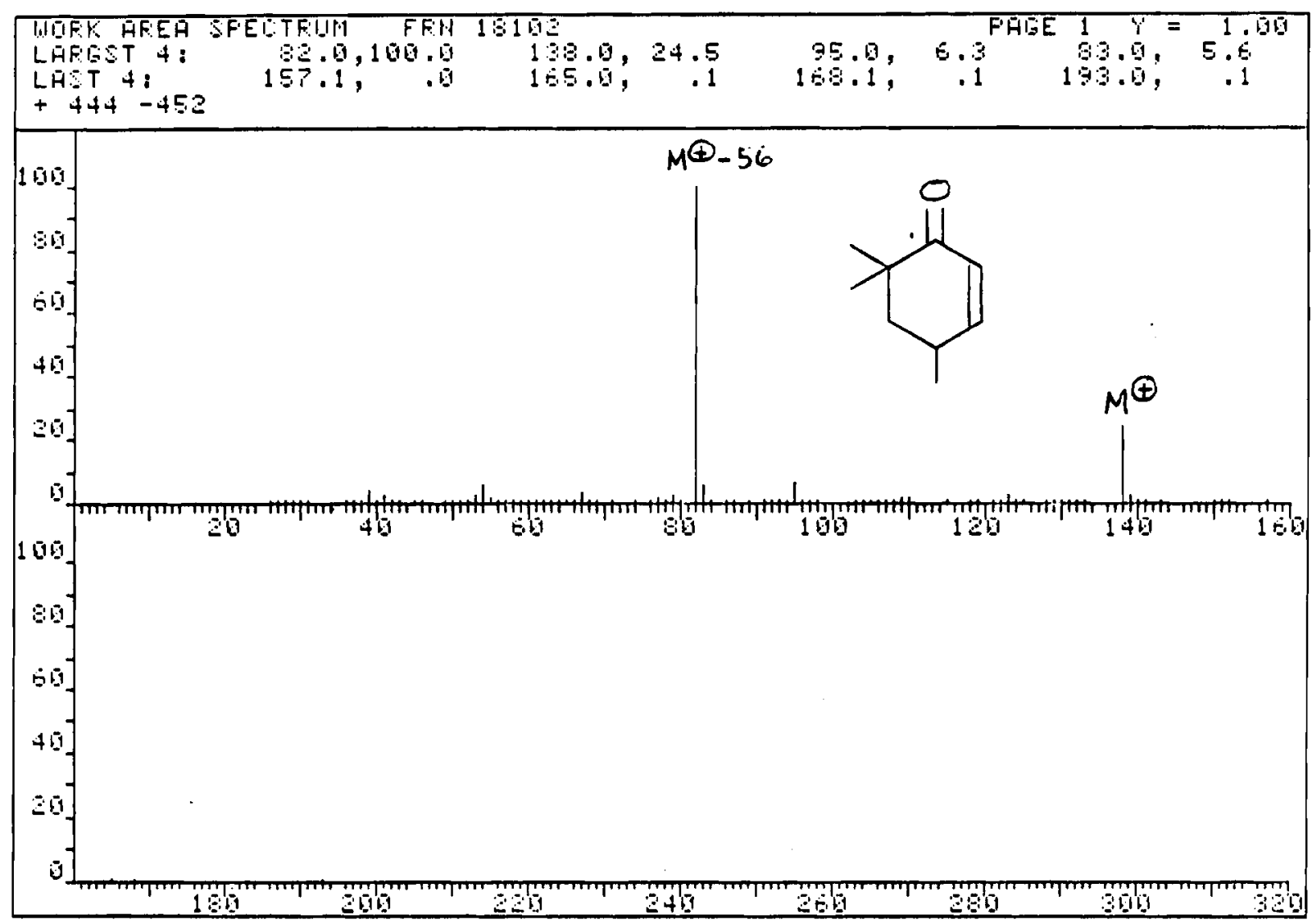

FIGURE 7. Mass Spectrum of 3,5,5-trimethyl-2-cyclohexen-1-one $(R T=22.0 \mathrm{~min})$

on the results of these additional studies, effective waste treatment trains can be designed to upgrade the quality of oil shale retort waters to meet future regulatory requirements prior to their disposal to the ground or recycle within oil shale pilot or commercial plant operations.

\section{LIQUID-LIQUID EXTRACTION}

Liquid-liquid (or solvent) extraction was investigated for the removal of organics from oil shale retort water. Advantages of extraction include: 


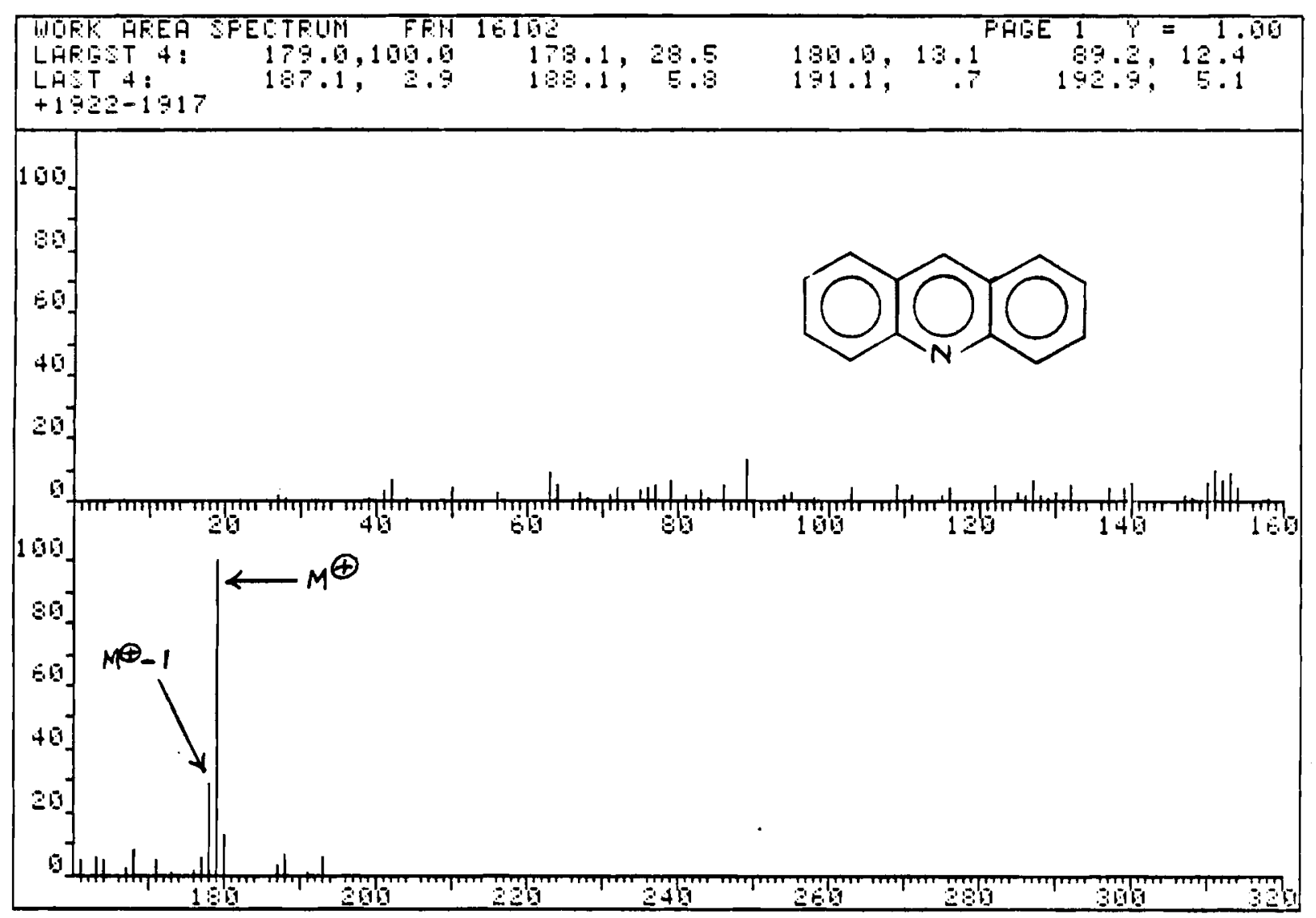

FIGURE 8. Mass Spectrum of Acridine (RT $=52.1 \mathrm{~min})$.

- A wide variety of solvents and solvent mixtures can be used. As a result, the process can be tailored to the retort water.

- Extraction is relatively insensitive to fluctuations in concentration. Wide fluctuations in retort water composition are expected because of variations in the oil shale.

- Unlike biological oxidation, extraction is not affected by toxic compounds.

- In extraction, the pollutants can be recovered and sold, thus partially offsetting the cost of wastewater treatment. 


\section{Process Description}

Liquid-1iquid extraction processes are generally composed of three partsextraction, solvent regeneration, and solvent recovery (Figure 9). In the extraction step, solvent and wastewater are mixed and the contaminants are transferred from the wastewater to the solvent. Because of the large volume of retort water, a differential mechanical contractor (essentially a column with rotating plates inside) would probably be used.

In the solvent regeneration step, the pollutant is separated from the solvent so the solvent can be recycled to the extractor. Distillation is the most commonly used separation method. When a high boiling solvent is used, only the pollutants must be vaporized overhead and little energy is used. However, high boiling contaminants and degradation products build up in the solvent. Use of a low boiling solvent requires more energy but a clean solvent is produced. Because of the variety of contaminants in retort water, two distillation columns may be required. The low volume concentrated pollutant stream may be recycled for its energy content or further purified for sale.

In the solvent recovery step, residual solvent is removed from the treated wastewater. If a volatile solvent is selected, steam stripping can be used to remove the solvent as well as ammonia and hydrogen sulfide.

Extraction processes are usually not capable of reducing contaminant aqueous phase concentrations below about $10 \mathrm{mg} / 1$ and a polishing step such as

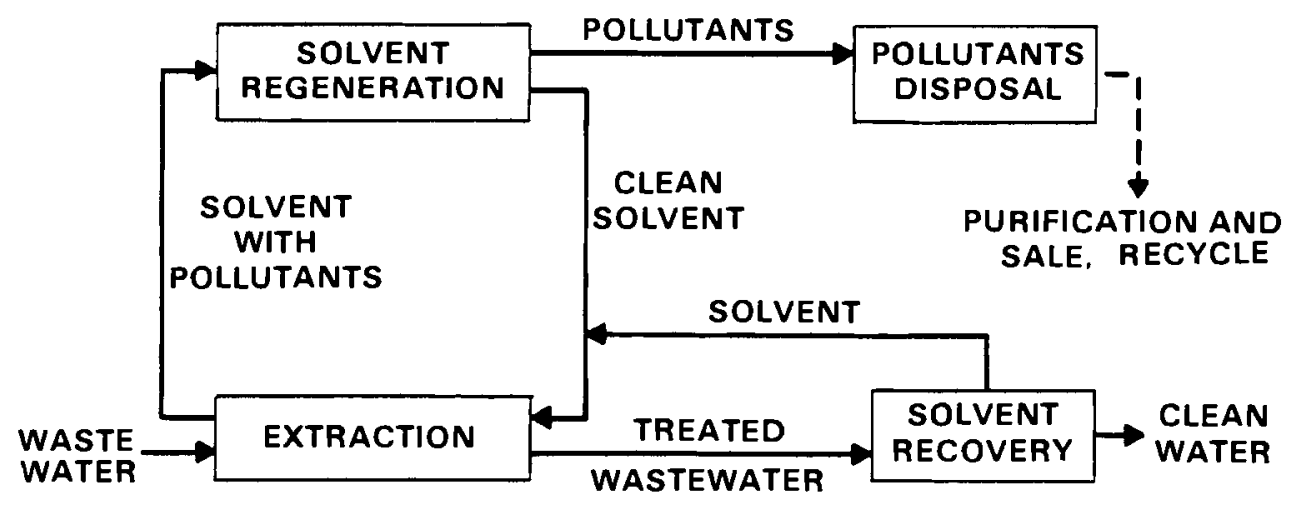

FIGURE 9. Typical Solvent Extraction Process 
biological oxidation or carbon adsorption may be required (Kiezyk and Mackay, 1971). Extraction costs tend to be proportional to the amount of wastewater treated while biological oxidation and carbon adsorption costs tend to be proportional to the amount of pollutant removed; thus, extraction is more cost effective at higher pollutant concentration levels.

The two major costs of a liquid-liquid extraction system are operation of the solvent regeneration (distillation) tower and amortization of equipment. Reducing the solvent-to-wastewater ratio in the extractor and increasing the size (number of stages) of the extraction column usually reduces total costs (Hanson, 1968). Liquid-liquid extraction costs vary widely with the application. Helsel (1976) claimed costs of $\$ 0.20$ per 1000 gal for extraction of acetic acid from pharmaceutical wastewater. Earhart et al., (1976) report cost estimates of $\$ 0.71$ per 1000 gal for extraction of n-butyl acetate by isobutylene and \$1-3 per 1000 gal for extraction of diethylene dichloride by isobutylene. Lyman (1978) estimated a cost of $\$ 10.76$ per 1000 gal for extraction of phenol by toluene. Similarly, Lorton (1978) estimated a cost of $\$ 10.76$ per 1000 gal for extraction of phenolics from coal gasification wastewater by methyl isobutyl ketone. Thus, a rough estimate of costs for extraction of retort water would be \$1-10 per $1000 \mathrm{gal}$. Costs would be reduced if any of the pollutants were purified and sold.

The technical and economic feasibility of an extraction system strongly depends on the solvent or mixture selected. Selection is based on the extractive ability of the solvent, ease of regeneration, density, solubility in water, viscosity and interfacial tension, price and availability, chemical stability, and safety and toxicity.

Most of the organic compounds identified in retort water are polar and should be most easily removed by polar solvents. A large fraction of the organics are carboxylic acids. Brown (1963) and Weaver and Biggs (1961) investigated the economics of extraction of acetic acid from cellulose acetate and pulp mill (NSSC process) wastewaters. They found that ketones, esters, and ethers were most effective. These solvent classes are also being considered for treatment for coal gasification and liquefaction wastewaters (Greminger, 1979; Parsons and Nolde, 1977). 
Batch Equilibrium Experiments

Preliminary work indicated that methyl isobutyl ketone (MIBK) removed 30 to $40 \%$ of the total organic carbon in steam - stripped retort water. Because alkylpryridines appear to be the most mobile organic contaminants in retort waters, further work was concentrated on removal of these compounds.

Five cormon extraction solvents of varying polarity were selected for laboratory tests. These were toluene, n-octanol, ethyl acetate, methyl isobutyl ketone and chloroform. Filtered retort water was shaken with each of the solvents in a separatory funnel for 2 min and allowed to settle for $10 \mathrm{~min}$. Triplicate extractions at a solvent to feed ratio of $2: 1(10 \mathrm{ml}: 5 \mathrm{ml})$ were performed. The organic phase was removed, concentrated under a stream of nitrogen and internal standard (benzanilide) added. Samples were analyzed for alkylpyridines by capillary gas chromatography.

The GC procedure was similar to that used for the steam - stripped samples, except that a nitrogen-specific detector was used in combination with a standard pyridine mixture which contained pyridine, 4-methylpyridine, 2,5dimethylpyridine, and 2,4,6-trimethylpyridine.

Concentrations of alkylpyridines in the original retort water and in the solvent extracts are given in Table 8. Instrumental error was typically less than $2 \%$. Concentrations of alkylpyridines in the extracted water were determined by difference (concentration in original retort water-concentration in solvent extract $x$ volume ratio of solvent to aqueous phase).

Equilibrium distribution coefficients $\left(K_{e q}\right)$ are given in Table 9. Chloroform is the best solvent tested for removing low molecular weight pyridines from both $P$ araho and 0ccidental retort waters with $K_{\text {eq }}$ range of 1.2 - 1.3 for the total selected pyridines monitored. Toluene and n-octanol appeared to be the least efficient of the solvents tested ( $K_{\text {eq }}$ range 0.05 0.21). In general, the extraction coefficients correlated reasonably well with polarity (Snyder 1974). Solvent extraction processes are not usually cost effective unless $K_{e q}$ is greater than unity. On that basis chloroform is the only solvent worth investigating further. 
TABLE 8. Concentrations (mg/l) of Alkylpyridines in Solvent Extraction Experiments

\begin{tabular}{|c|c|c|c|c|c|c|}
\hline \multirow[b]{2}{*}{ Compound } & \multicolumn{6}{|c|}{ Paraho Retort Water } \\
\hline & Retort Water & Toluene (a) & n-0ctanol & Ethylacetate & MIBK & Chloroform \\
\hline Pyridine & $20.8 \pm 10.6$ & $1.0 \pm 1.0$ & $4.2 \pm 2.3$ & $2.9 \pm 0.9$ & (b) & $3.9 \pm 2.1$ \\
\hline$C_{1}$-Pyridine & $73.1 \pm 6.9$ & $3.2 \pm 0.5$ & $6.3 \pm 3.8$ & $19.1 \pm 0.7$ & $10.7 \pm 0.3$ & $20.9 \pm 5.2$ \\
\hline $\mathrm{C}_{2}$-Pyridine & $32.1 \pm 2.8$ & $7.8 \pm 0.9$ & $7.2 \pm 2.9$ & $7.7 \pm 1.2$ & $6.7 \pm 0.3$ & $14.6 \pm 2.3$ \\
\hline $\mathrm{C}_{3}$-Pyridine & $40.5 \pm 4.0$ & $12.3 \pm 0.3$ & $2.6 \pm 1.4$ & $15.2 \pm 1.5$ & $10.1 \pm 0.4$ & $18.8 \pm 1.9$ \\
\hline $\begin{array}{l}\text { Total } \\
\text { Selected } \\
\text { Pyridine }\end{array}$ & $166.5 \pm 24.3$ & $24.3 \pm 1.0$ & $20.2 \pm 1.8$ & $44.9 \pm 0.1$ & $27.5 \pm 0.3$ & $58.2 \pm 1.2$ \\
\hline
\end{tabular}

Occidental Retort Water

$\begin{array}{lcccccc}\text { Pyridine } & 2.3 \pm 0.5 & 0.4 \pm 0.1 & 0.2 \pm 0.1 & 0.3 \pm 0.3 & \text { (b) } & 0.6 \pm 0.2 \\ C_{1} \text {-Pyridine } & 12.8 \pm 0.1 & 0.2 \pm 0.2 & 0.6 \pm 0.6 & 0.3 \pm 0.3 & 0.1 \pm 0.1 & 3.7 \pm 5.1 \\ C_{2} \text {-Pyridine } & 13.1 \pm 8.8 & 0.8 \pm 0.0 & 0.7 \pm 0.0 & 2.1 \pm 0.8 & 1.3 \pm 0.8 & 4.6 \pm 1.1 \\ C_{3-P y r i d i n e} & 25.5 \pm 5.5 & 3.1 \pm 0.3 & 1.1 \pm 0.9 & 5.4 \pm 0.5 & 4.6 \pm 1.3 & 14.3 \pm 9.0 \\ \text { Total } & 53.6 \pm 14.9 & 4.5 \pm 0.2 & 2.5 \pm 1.6 & 8.0 \pm 1.9 & 7.4 \pm 2.1 & 19.3 \pm 9.8 \\ \text { Selected } & & & & & & \end{array}$

(a) Concentration as a result of a single equilibration

(b) Solvent interference 
TABLE 9. Equilibrium Distributions of Alkylpyridines

Paraho Retort Water

\begin{tabular}{|c|c|c|c|c|c|}
\hline Compound & Toluene & n-0ctano 1 & Ethy 1 Acetate & MIBK & Chloroform \\
\hline Pyridine & 0.05 & 0.34 & 0.19 & (b) & 0.30 \\
\hline $\mathrm{C}_{1}$-Pyridine & 0.05 & 0.10 & 0.55 & 0.21 & 0.67 \\
\hline $\mathrm{C}_{2}$-Pyridine & 0.47 & 0.41 & 0.46 & 0.36 & 5.0 \\
\hline$C_{3}$-Pyridine & 0.77 & 0.07 & 0.51 & 0.50 & 6.5 \\
\hline $\begin{array}{l}\text { Total } \\
\text { Selected } \\
\text { Pyridine }\end{array}$ & 0.21 & 0.16 & 0.59 & $0.25(c)$ & 1.2 \\
\hline
\end{tabular}

Occidental Retort Water

B

$$
\begin{aligned}
& \text { Pyridine } \\
& C_{1} \text {-Pyridine } \\
& C_{2} \text {-Pyridine } \\
& C_{3} \text {-Pyridine } \\
& \text { Total } \\
& \text { Selected } \\
& \text { Pyridine }
\end{aligned}
$$

\begin{tabular}{lllll}
\hline 0.27 & 0.11 & 0.18 & (b) & 0.55 \\
0.02 & 0.05 & 0.02 & 0.01 & 0.69 \\
0.07 & 0.06 & 0.24 & 0.12 & 1.2 \\
0.16 & 0.05 & 0.37 & 0.28 & (d) \\
0.10 & 0.05 & 0.21 & $0.19(\mathrm{c})$ & 1.3
\end{tabular}

(a) $\mathrm{K}_{\text {eq }}=\frac{\text { Conc. Organic Phase }}{\text { Conc. Aqueous Phase }}(\mathrm{mg} / \mathrm{L} / \mathrm{L}$, by difference) after extraction

(b) Solvent interference

(c) Value calculated with the exclusion of pyridine

(d) The amount of $C_{3}$-pyridine extracted was measured to be greater than the measured initial amount of $C_{3}$-pyridine which is not physically possible. Therefore, Keq cannot be determined but is very large. 
As expected, all solvents appeared to be more efficient in removing the higher molecular weight alkylpyridines $\left(C_{2}\right.$-pyridines, $C_{3}$-pyridines) as opposed to the lower molecular weight pyridines (pyridine, $c_{1}$-pyridines). The higher molecular weight compounds should have lower polarities and thus be more easily extracted into organic solvents. Since lower molecular weight compounds are more easily steam strippęd, being more volatile, one process option is extraction of high molecular weight pyridines followed by stream stripping to remove both low molecular weight pyridines and the solvent.

Alkylpyridines in the Paraho retort water appeared to be easier to extract than those in 0ccidental retort water. This could be due to differences in either composition of $\mathrm{pH}$ (Paraho 7.0-7.50, Occidental 9.5) of the two waters. Even trace amounts of some compounds can alter interfacial tension, which affects settling of the two phases (required for phase separation and recycle) and mass transfer rates between the two phases (Treybal 1966).

\section{BIOLOGICAL TREATMENT}

Biological treatment is widely used for removal or stabilization of organic matter in municipal and industrial wastewaters. It is generally the most cost effective method for dealing with organic pollutants in wastewater. The testing or two biological treatment processes, activated sludge and anaerobic digestion with retort water, has been reported by Mercer et al. (1982) and will be reviewed in this section.

\section{Process Description}

\section{Activated Sludge}

In the activated sludge process, wastewater containing organic matter is fed to the aerobic reactor (aeration tank) which furnishes: 1) air required by microorganisms to biochemically oxidize the waste organics and 2) mixing to ensure close contact of microorganisms with the organic waste (see Figure 10). The contents of the reactor are referred to as mixed liquor (i.e., wastewater and activated sludge). In the vigorously mixed aerobic reactor, most organic wastes are metabolized to provide energy and growth factors for the production of more microorganisms with the release of carbon dioxide and water and heat 


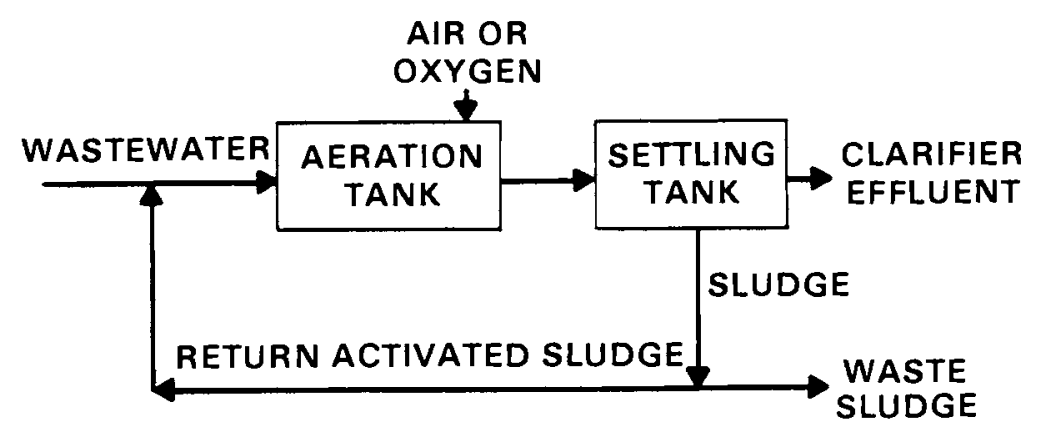

FIGURE 10. Diagram of Activated Sludge Process

energy as metabolic end products. Thus, most organic waste compounds are degraded to innocuous end products and microorganisms (i.e., sludge). Complex organic compounds may only get partial degradation.

The mixed liquor flows from the aeration tank to a sedimentation tank which provides quiescent settling to allow separation of the biological solids from the treated wastewater. The treated and clarified water is collected and discharged as process effluent. Most of the settled biological solids are recycled as return activated sludge back to the aerobic reactor. Recycling provides an activated mass of microorganisms for continuous treatment of incoming wastewater. Some of the settled biological solids (microorganisms) are wasted to maintain a proper balance in the population of microorganisms in the mixed liquor of the aerobic reactor. Recycling and wasting of biological solids from the reactor ensures a proper ratio of incoming waste to the population of microorganisms (food to microorganisms, or $F / M$ ratio), which is critical to efficient biodegradation of organic waste compounds. Good flocculation and settling of the activated sludge is important for the recovery and recycle of sufficient microorganisms for effective operation of the process and to minimize the amount of organic matter in the effluent. Excess activated sludge is generally produced by this process which will require disposal. Since the activated sludge may accumulate toxic constituents (e.g., heavy metals) from the retort water, careful consideration should be given to selection of a suitable disposal method. 


\section{Anaerobic Digestion}

The anaerobic digestion process employs microorganisms which decompose certain types of organic substances without using molecular oxygen. Decomposition is accomplished by two groups of bacteria. One group of bacteria, called the "acid formers," carry out the first step in the process which is the conversion of complex organics into simple organic acids such as acetic and propionic acids. The other group of bacteria, called the "methane formers," convert the organic acids to methane and carbon dioxide in the second step of the process. The two groups of bacteria must operate in a state of dynamic equilibrium to effectively stabilize an organic waste. Decomposition of waste organic matter is generally accomplished in an enclosed vessel called a "digester". Air or oxygen must be excluded from the digester.

The principal advantages of anaerobic digestion include: 1) low sludge production which minimizes the typically high cost of sludge disposal and 2) the production of methane gas as a useful byproduct. The major disadvantage is operational control which is generally more difficult than for an aerobic process. The growth rate of the methane formers is slow, and relatively long time periods are required to establish steady state.

\section{Treatment Studies}

\section{Activated Sludge}

Several unsuccessful attempts were made to acclimate activated sludge cultures to Geokinetics in situ retort water. Successful acclimation was achieved when the $\mathrm{pH}$ was carefully controlled $(7.0 \pm 0.5)$ and the retort water was initially pretreated with activated carbon. Two fill-and-draw activated sludge reactors with one liter of mixed liquor in each were used to evaluate this process on steam-stripped Geokinetics retort water (Mercer et al. 1982). Activated sludge from a petroleum refinery wastewater treatment plant was found to be readily acclimated to retort water that had been treated with a column of granular activated carbon. Step-wise increases in the percent of noncarbon treated retort water over a period of 5 weeks produced an activated sludge which was effective in treating this retort water. Treatment with powdered activated carbon (PAC) was evaluated in one test concurrently with no 
PAC treatment in the other test. Feed compositions are given in Table 10 for steam-stripped Geokinetics No. 3 and 4 retort water used in the tests. Both retort waters were initially pretreated for arsenic removal to avoid potential toxicity problems with this element. Pretreatment for arsenic removal consisted of ferric hydroxide-manganese dioxide scavenging which will be discussed in the section on heavy metals scavenging. Figures 11 and 12 illustrate influent and effluent TOC concentration, organic loading (TOC/MLVSS) and $\mathrm{pH}$. The data also include the final two-step increases ( 80 and $90 \%$ ) of the acclimation period. PAC treatment for the first 21 days in Figure 11 consisted of contacting the feed batch used each day with $2000 \mathrm{mg} / 1$ PAC in a mixing vessel for 10 min, then filtering the liquid to remove the PAC. Approximately $800 \mathrm{mg} / 1$ of PAC was in the mixed liquor of the PAC test at the beginning of the time period indicated in Figure 11 , but this diminished to about $300 \mathrm{mg} / 1$ at the end of the 21-day period because of sludge wasting. The daily treatment of the feed with $2000 \mathrm{mg} / 1$ PAC removed on $1 y$ 6\% of the TOC from the feed, but when coupled with the presence of PAC in the mixed liquor it appeared to be somewhat effective in reducing the stress of toxicants on the activated sludge. Microscopic examination of the activated sludge in each test vessel indicated a loss of rotifers, stalked and mobile ciliates and worms during the acclimation period. However, the PAC test reactor retained flagellates that were not retained by the reactor receiving no PAC treatment. Furthermore, the removal of thiocyanate, $\mathrm{CNS}^{-}$, was considerably greater for PAC treatment (see Figure 13) than without PAC treatment (see Figure 14). 
TABLE 10. Feed Compositions for Activated Sludge Test Reactors

\begin{tabular}{|c|c|c|c|}
\hline & $\begin{array}{r}\text { With As } \\
\text { Pretreat } \\
\text { Geokinetics } \\
\text { No. } 3 \\
\end{array}$ & $\begin{array}{l}\text { emoval } \\
\text { t, mg/1 } \\
\text { Geokinetics } \\
\text { No. } 4 \\
\end{array}$ & $\begin{array}{c}\text { Without As Removal } \\
\text { Pretreatment, mg/l } \\
\text { Geokinetics } \\
\text { No. } 4 \\
\end{array}$ \\
\hline TOC & 1010 & 1360 & 1380 \\
\hline COD & 3910 & 5400 & 5990 \\
\hline $\mathrm{CNS}^{-}$ & 315 & 250 & 250 \\
\hline $\mathrm{S}_{2} \mathrm{O}=$ as $\mathrm{s}$ & 890 & 990 & 1450 \\
\hline $\mathrm{BOD}(\mathrm{a})$ & -- & 1300 & --- \\
\hline As & 0.8 & 1.4 & 8.5 \\
\hline
\end{tabular}

(a) Probably includes little, if any, oxygen demand from thiosulf ate.

Some of this difference in $\mathrm{CNS}^{-}$removal may be attributed to a lower organic and COD loading in PAC-treated reactor since this reactor received an average of about 20\% less TOC and COD than the reactor with no PAC treatment. During periods when the PAC-treated reactor received a $12 \%$ lower organic loading (Figure 11, Days 26-33; and Figure 12, Days 8-15), the percent TOC and COD removals were only slightly better with PAC treatment (see Table 11).

Thiosulfate removal was $95 \%$ in each reactor during these periods and remained above $93 \%$ until the end of each test. A BOD removal of greater than 99\% was measured on the reactor receiving no PAC treatment. However, the BOD results are suspected of not representing the true BOD values, since little, if any, thiosulfate oxygen demand may be included. Nevertheless, because more than $95 \%$ of the thiosulfate is oxidized, high BOD removals would be anticipated. PAC treatment was modified at the 22-day point on Figure 11 to addition of $300 \mathrm{mg} / 1$ PAC to the feed as before, but with settling after the 10-min contact period. The settled PAC was then separated by decanting the supernatant liquid and the PAC was added directly to the reactor as a slurry in about $10 \%$ of the daily feed volume. The reactor volume was also reduced to $500 \mathrm{ml}$ of mixed liquor at this point to extend the test period with the limited amount of retort water available. A $10 \%$ reduction in TOC removal occurred the day after this modification which also coincided with a pH increase. Insufficient 


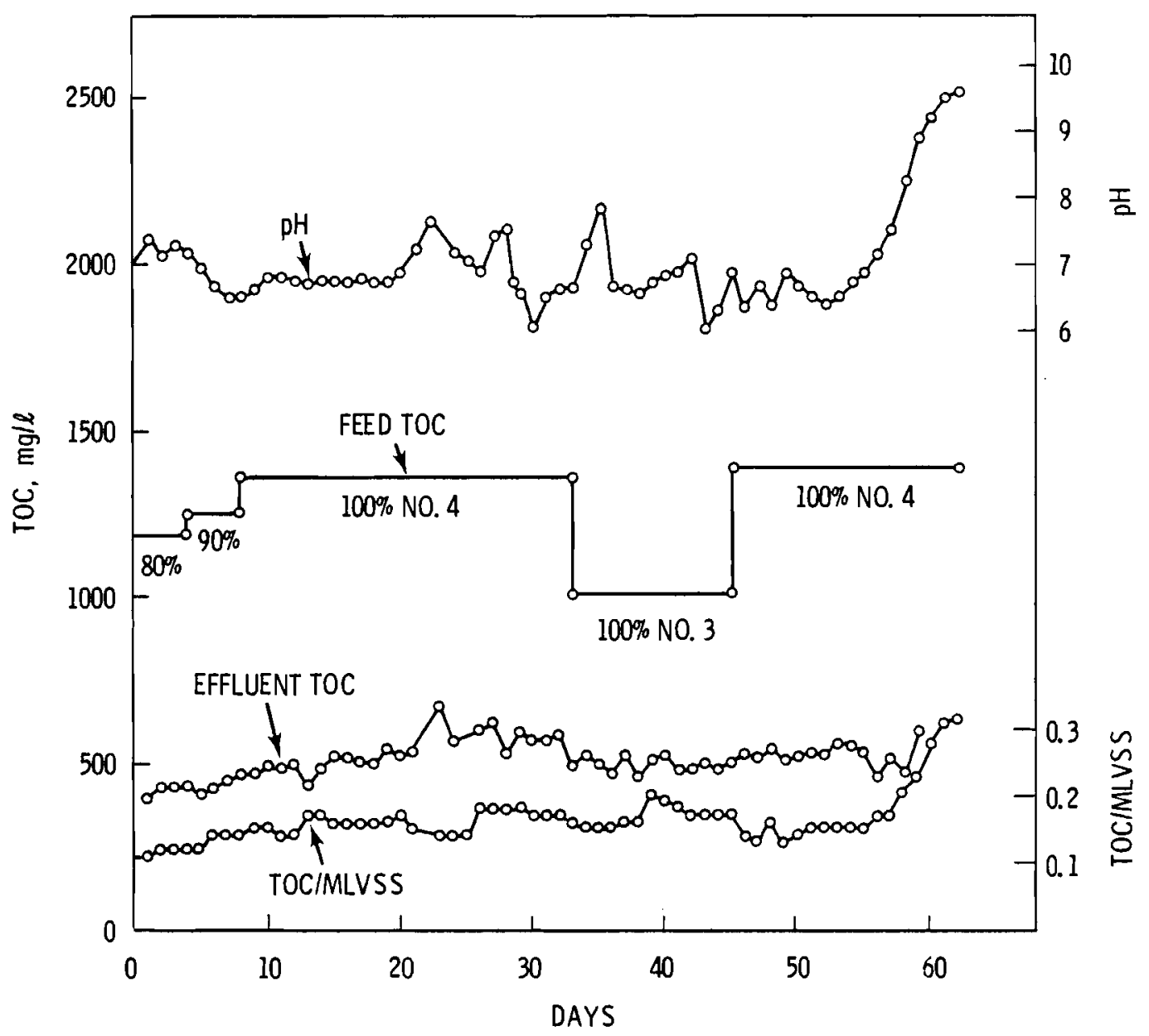

FIGURE 11. Organic Carbon Influent, Effluent and Loading Values with PAC Treatment. MLVSS averaged $4300 \mathrm{mg} / 1$ from day 8 to day 33 with a solids retention time of about 20 days.

time for $\mathrm{pH}$ stabilization after acid addition to the feed is believed responsible for this $\mathrm{pH}$ increase. The $\mathrm{pH}$ fluctuations that occurred during the Geokinetics No. 3 feed addition resulted from the lack of phosphate buffering. Phosphate buffer was not used during this period since the phosphate interferred with the alum coagulation tests planned for this effluent.

The reactor receiving no PAC treatment appeared to be stabilizing with respect to TOC removal in the final six days with No. 4 feed; however, the test period was too short to actually confirm this. A substantial decrease in CNS removal occurred during this time, which may be attributed to the $12 \%$ increase 


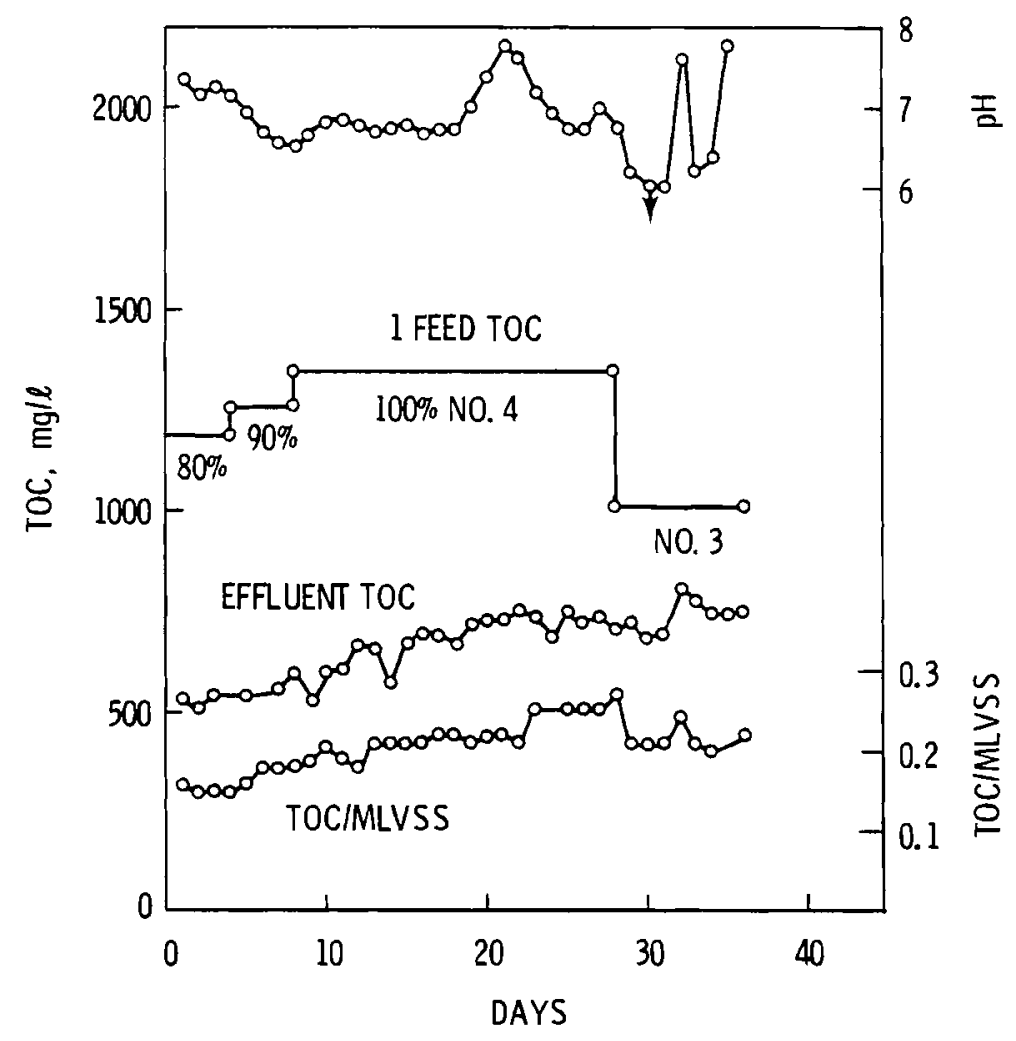

FIGURE 12. Organic Carbon Influent, Effluent and Loading Values Without PAC Treatment

in organic loading. Unfortunately $\mathrm{pH}$ control was lost after this when No. 3 feed was introduced without phosphate buffering. A pH reduction to 4.2 was experienced on Day 30 of Figure 12 and the test was terminated several days later when CNS $^{-}$removal dropped to near zero.

Sufficient $\mathrm{pH}$ control was maintained in the test reactor receiving PAC to sustain good biological oxidation of $\mathrm{CNS}^{-}$contained in the No. 3 feed. However, the percentage of TOC and COD removed from No. 3 feed was less than that for No. 4 feed. The introduction of No. 4 feed, without the arsenic removed after No. 3 was completed, did not appear to affect the operation of the test reactor. The phosphate buffer was not added to the No. 4 feed during the final week of this test to determine the effect of a pH increase on the operation of the reactor. The $\mathrm{pH}$ increase results from carbon dioxide stripping from the 


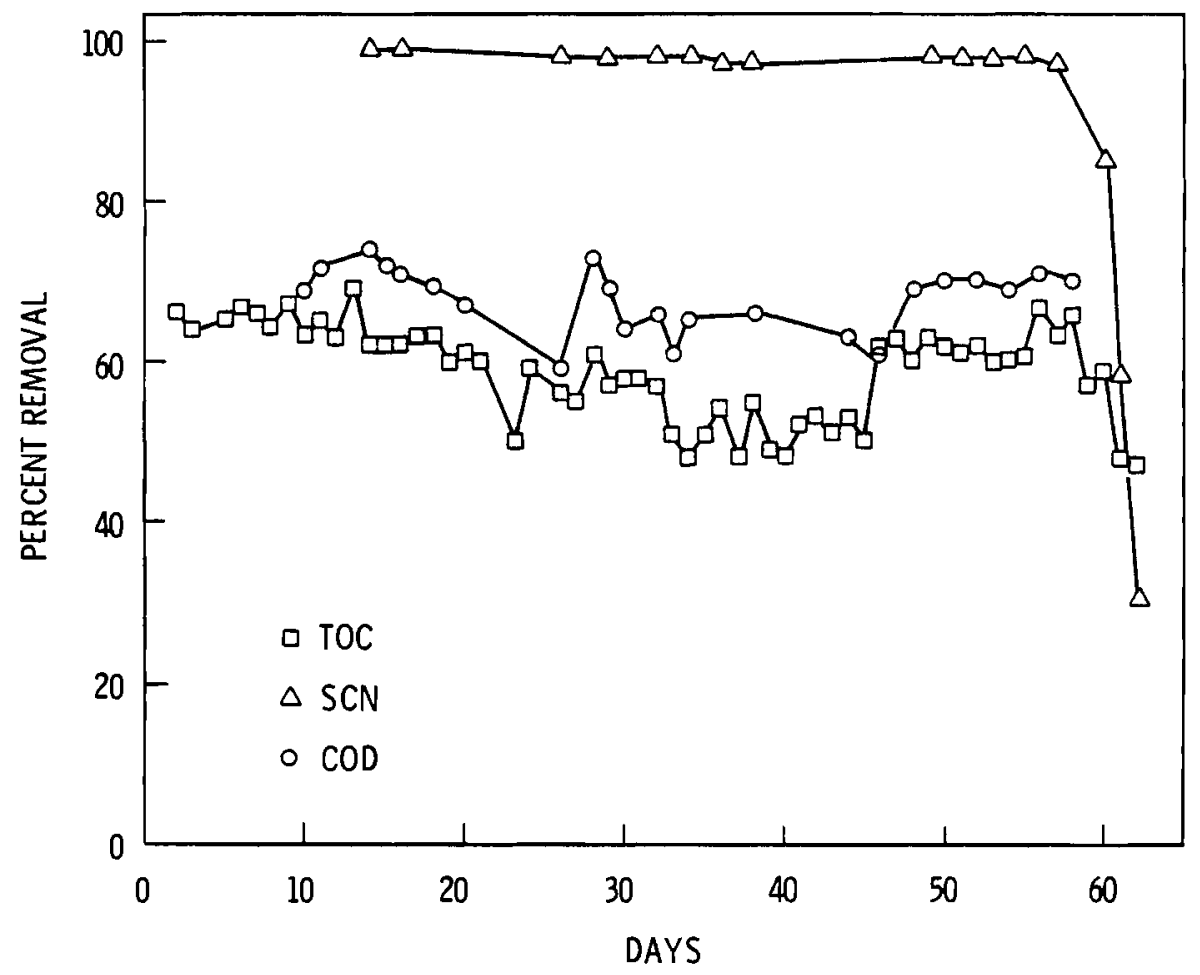

FIGURE 13. Removal of TOC, COD and Thiocyanate with PAC Treatment

high sodium bicarbonate concentration in the retort water during aeration. As evident in Figure 13, TOC and $\mathrm{CNS}^{-}$reduction decreased rapidly coinciding with the $\mathrm{pH}$ increase.

\section{Anaerobic Digestion}

A series of five test with 3.51 digesters were performed with Geokinetics, Paraho and simulated in situ retort waters (Mercer et al. 1982). Powdered activated carbon $(2000 \mathrm{mg} / 1)$ was added to the feed to each reactor. Successful operation was achieved only with the simulated in situ retort water. The presence of relatively high concentrations of thiosulfate and other sulfur species in Geokinetics and Paraho retort waters is believed to have contributed substantially to the toxicity problem through the formation of hydrogen sulfide in the digesters. 


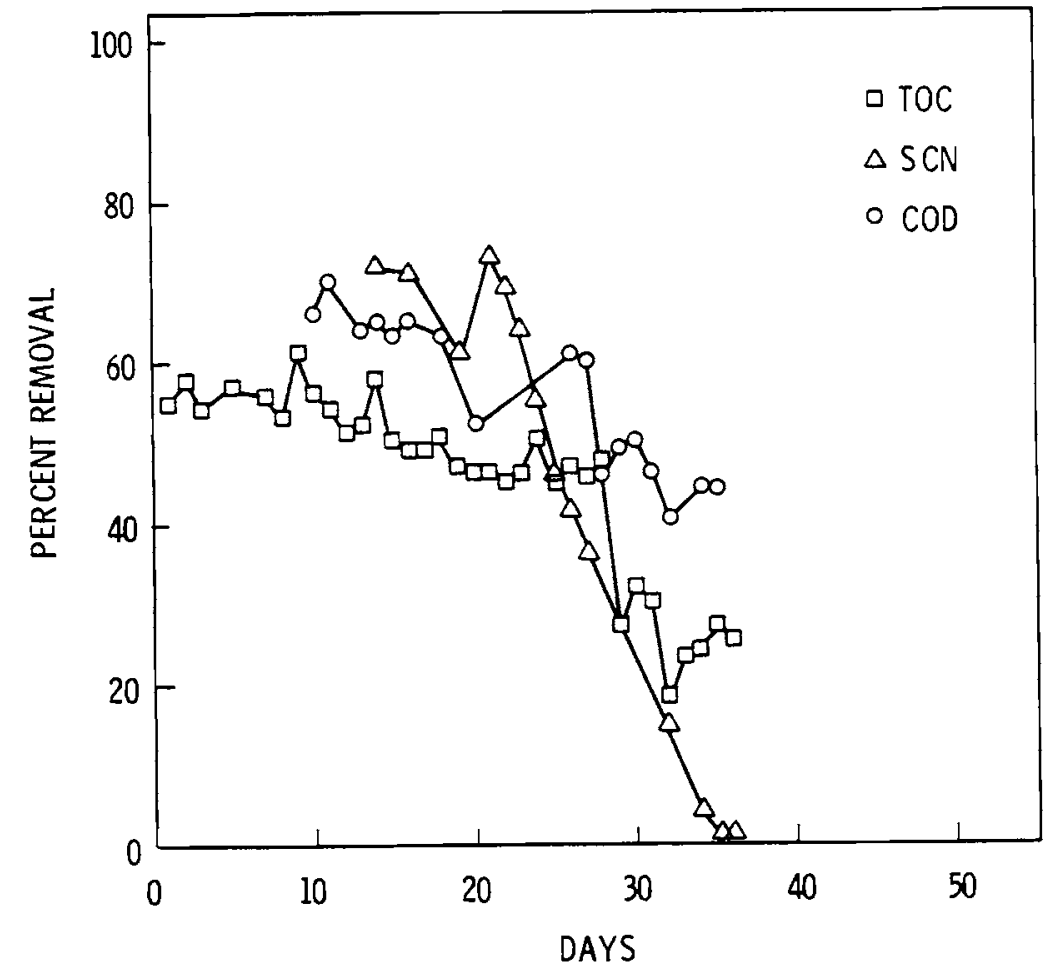

FIGURE 14. Removal of TOC, COD and Thiocyanate Without PAC Treatment

TABLE 11. Comparison of Pollutant Removals with Activated Sludge with and Without PAC Treatment

With PAC Treatment, Without PAC Treatment, \% Removal \% Removal

Pollutant (Figure 19, Days 26-33) (Figure 20, Days 8-15)

TOC

57

55

COD

$B O D^{(a)}$

66

65

$\mathrm{S}_{2} \mathrm{O}_{3}=$

$-$

99

$\mathrm{SCN}^{-}$

95

95

99

72

(a) Probably includes little, if any, effect from thiosulf ate oxygen demand. 
ACTIVATED CARBON ADSORPTION

Activated carbon adsorption is typically used after biological treatment to remove residual nonbiodegradable (or refractory) organic matter. Adsorption of organic pollutants from wastewater can be accomplished with either powdered activated carbon applied in batch contact operations or with granular activated carbon applied in column operations. Column operations are generally preferred where it is desired to maximize organic loadings on the carbon and attain high removal efficiencies. Furthermore, the technology for regenerating granular activated carbon is better developed than for powdered activated carbon.

Process Description

Column operations may be conducted with either fixed beds or continuous columns. Fixed beds are generally used in small operations where the carbon is not regenerated on site. The carbon is either discarded when it becomes exhausted or returned to the vendor for regeneration. Continuous column operations frequently employ on site regeneration as illustrated in Figure 15 . The wastewater influent flows counter-current to the carbon coming into the column; therefore the effluent has contacted the freshest carbon to attain low concentrations of adsorbate. The nearly exhausted carbon first contacts the influent which maximizes the extraction of adsorbate. Exhausted carbon is withdrawn from the bottom of the column, transferred to the regeneration furnace, and

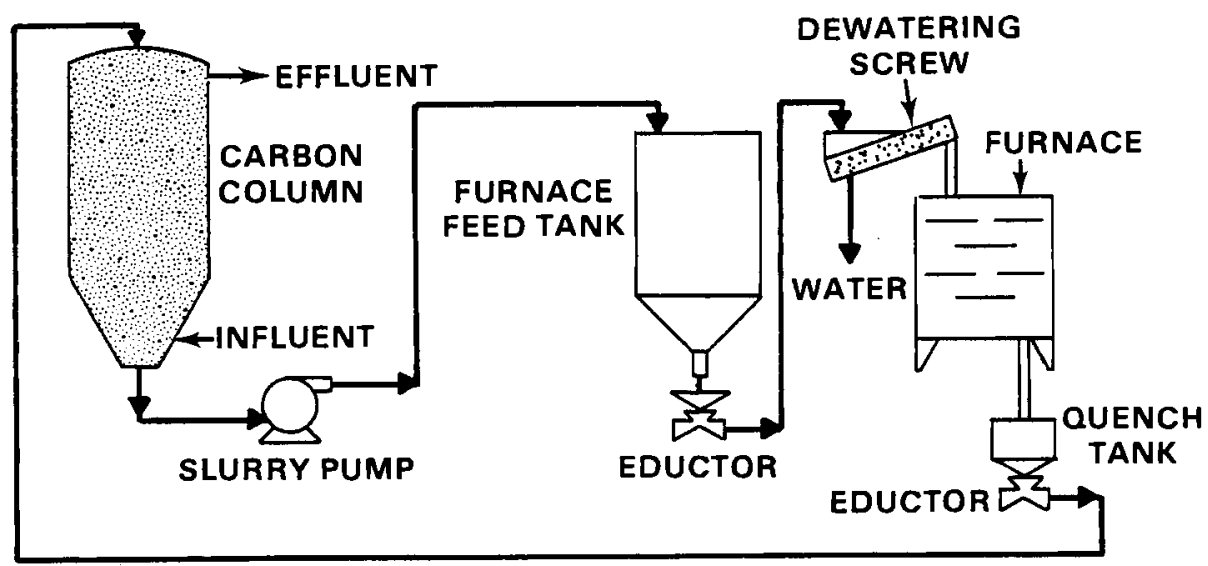

FIGURE 15. Simplified Flowsheet of a Granular Activated Carbon Column with a Thermal Regeneration System 
then returned to the top of the column. The rate at which the carbon is regenerated and returned to the column is governed by the quality of effluent desired. Higher quality effluent requires a higher generation rate. In a true continuous column operation, the effluent quality is constant as opposed to a fixed bed operation where the effluent quality is high at the beginning but deteriorates as the column becomes exhausted. Pilot piant testing is recommended for most column wastewater treatment applications to establish feasibility and costs and to optimize operating conditions.

Bench-Scale Treatability Studies

Adsorption isotherm tests were performed on steam-stripped Geokinetics No. 3 retort water with and without biological treatment (Mercer et al. 1982). The bio-treated water consisted of alum clarified and filtered effluent from the activated sludge test unit receiving steam-stripped feed with $300 \mathrm{mg} / 1 \mathrm{PAC}$ (see Figure 11). Only combined effluent from day 40 to day 45 of the activated sludge experiment was used to allow flushing of phosphate buffer and previous feed solution from the test unit. Only nutrient phosphorus at a concentration of $43 \mathrm{mg} / 1 \mathrm{PO}_{4}-\mathrm{P}$ was added to the feed of the activated sludge unit. A minimum phosphate addition was desired during this phase of the activated sludge to avoid interference with the alum coagulation step. A rapid settling floc was obtained by adding $300 \mathrm{mg} / 1$ alum and $1 \mathrm{mg} / 1$ anionic polymer to the activated sludge effluent. Small beaker tests indicated that $300 \mathrm{mg} / 1$ alum was optimum for clarification of the effluent. The alum clarified effluent was adjusted to $\mathrm{pH} 7.0$ and filtered with a 0.45 membrane filter to remove the remaining traces of suspended matter. One hundred $\mathrm{ml}$ portions of the filtered effluent were placed in $250 \mathrm{ml}$ beakers equipped with magnetic stirrers. From 0.5 to $5 \mathrm{mls}$ of $200 \mathrm{~g} / 1$ activated carbon slurry (Calgon Filtrsorb 400) were also added to each beaker. The volume of mixture in each beaker was adjusted to $105 \mathrm{ml}$ with distilled water and the contents were vigorously mixed for one hour. At the end of the mixing period the slurry was filtered through a $0.45 \mu$ membrane filter and the filtrate was analyzed for TOC. Two blanks were determined by the same procedure, but without addition of activated carbon. The blanks were used to establish the initial TOC concentrations which were slightly lower $(\sim 5 \%)$ than feed solution due to adsorption on the filter and 
walls of the containers. An adsorption isotherm was also determined for steamstripped Geokinetics No. 3 retort water which had not received biological treatment. This water was adjusted to $\mathrm{pH} 7.0$ and filtered through a $0.45 \mathrm{\mu}$ membrane filter without alum treatment.

The activated carbon adsorption data were plotted according to the Freundlich equation which has the form:

$$
\frac{x}{m}=k c_{f}^{\frac{1}{n}}
$$

where

$$
\begin{aligned}
x & =\text { amount of solute adsorbed, } \mathrm{mg} / 1 \\
m & =\text { weight of carbon, } g / 1 \\
C_{f} & =\text { concentration of solute in solution at equilibrum, } \mathrm{mg} / 1 \\
K & =\text { intercept at } C_{f}=1 \\
\frac{1}{n} & =\text { slope of the line. }
\end{aligned}
$$

In logarithmic form, this equation is:

$$
\log \frac{x}{m}=\log K+\frac{1}{n} \log C_{f}
$$

The adsorption data for the steam-stripped retort water with and without biological treatment was plotted in Figure 16. The TOC isotherm for the biotreated retort water is higher than the nonbiotreated retort water and has less slope which indicates that the TOC adsorption capacity is greater and decreases less rapidly with decreasing $C_{f}$ values. It can be predicted from these data that lower TOC effluents can be achieved with a given amount of carbon with biotreated retort water than with nonbiotreated retort water. Biological treatment effectively complements activated carbon adsorption by removing constituents such as lower aliphatic acids which are not adsorbed well by activated carbon at near neutral pH levels. 


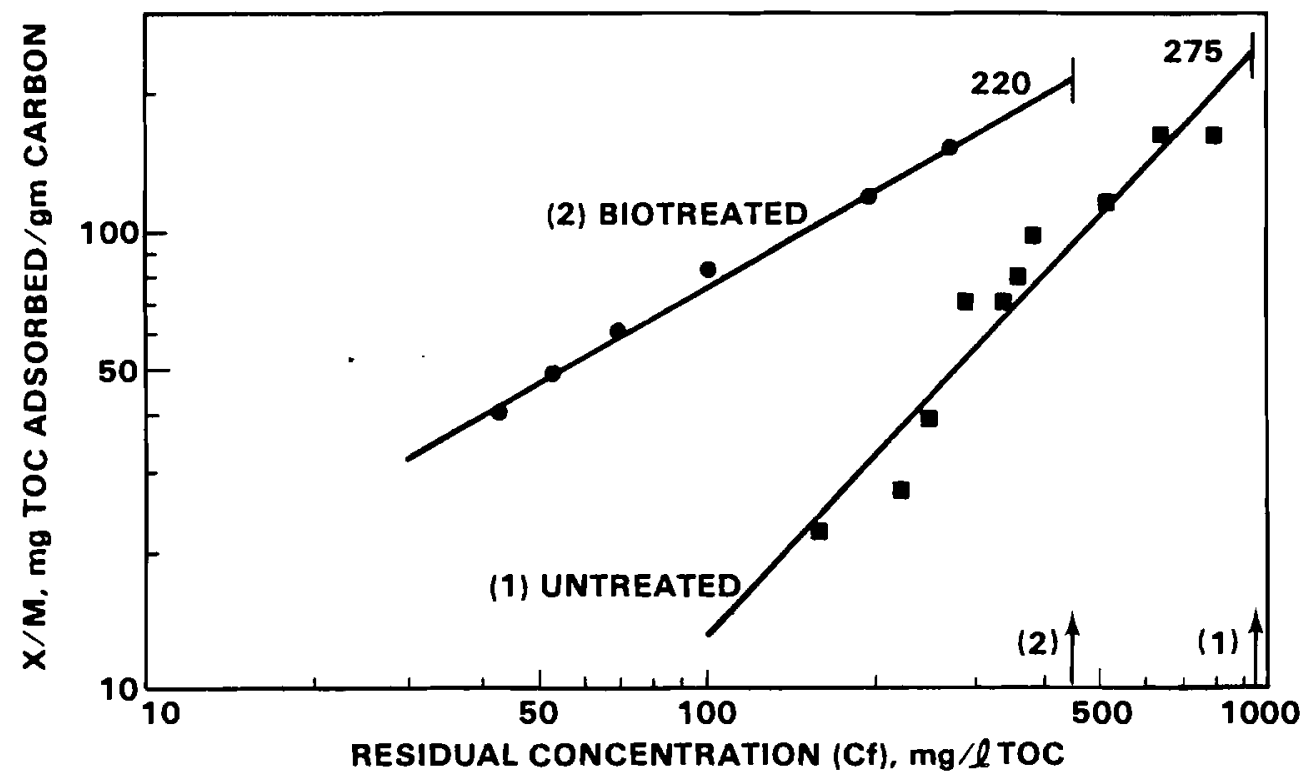

FIGURE 16. Carbon Adsorption Isotherms

Values for the slope of the lines $\left(\frac{1}{n}\right)$, intercept $(K)$, and the correlation coefficient $(r)$ are given below:

\section{With Biotreatment Without Biotreatment}

$\begin{array}{lll}\frac{1}{n} & 0.70 & 1.376 \\ k & 3.04 & 0.022 \\ r & 0.99 & 0.96\end{array}$

The intercept $K$ is roughly an indicator of the TOC adsorption capacity and is about two orders of magnitude larger for biotreated retort water than for nonbiotreated retort water. The correlation coefficient $r$ is computed by linear regression analys is and denotes how closely the data points fit the line $(r=1$ for a perfect fit).

Figure 17 illustrates TOC removal with a granular activated carbon column receiving biotreated and nonbiotreated steam stripped Geokinetics No. 4 retort water. Breakthrough of TOC occurred very early with the nonbiotreated retort water. Activated carbon adsorption was effective for removing color and odor which was not removed by biological treatment. 


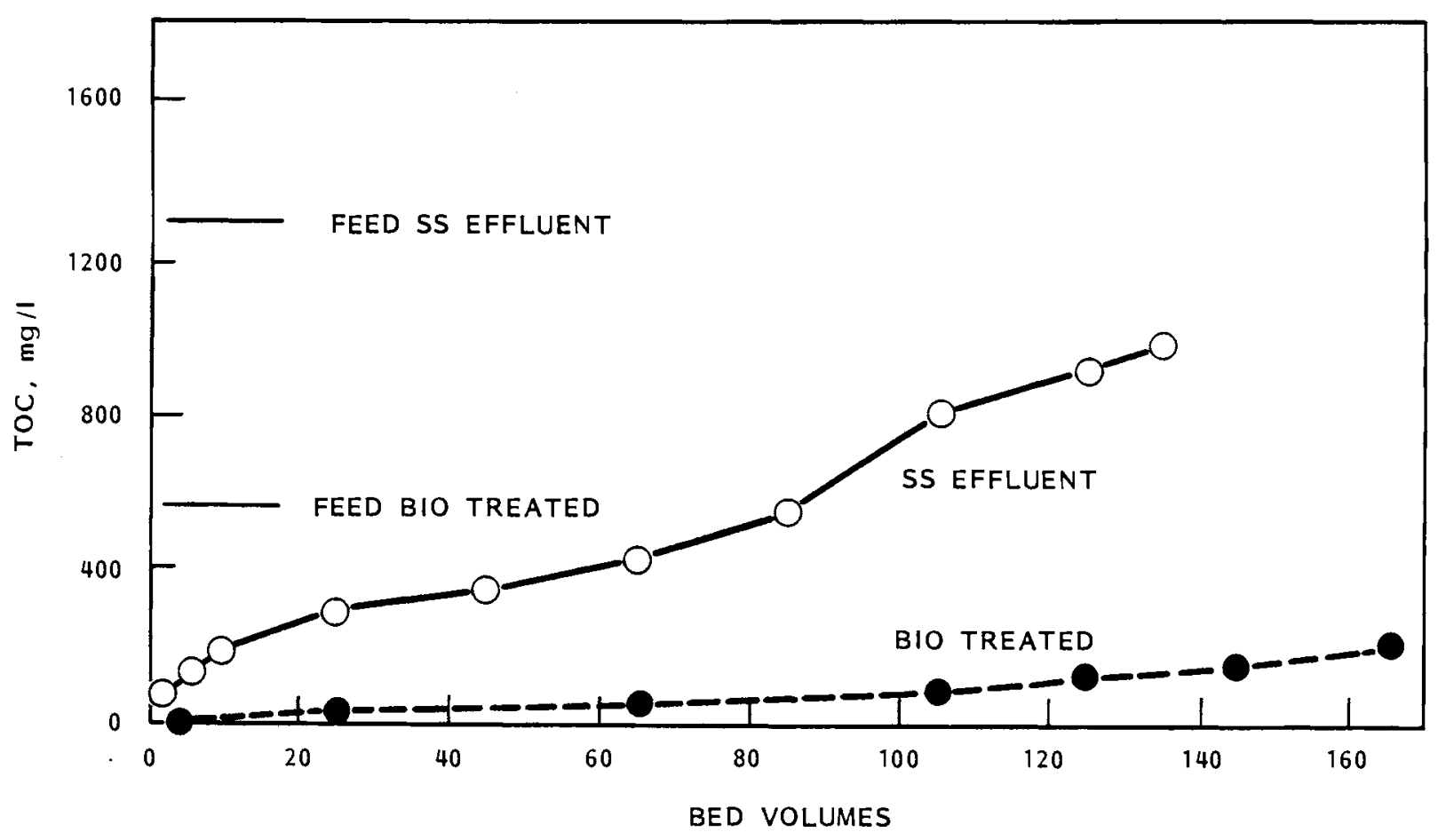

FIGURE 17. Activated Carbon Treatment TOC Removal

Experimental Conditions:

Column Dimensions: $1.8 \mathrm{~cm}$ diameter, $10 \mathrm{~cm}$ high Activated Carbon: $50 \times 20$ mesh/Filtrasorb 400 Flow Rate:

$39 \mathrm{ml} / \mathrm{min}$

A preliminary cost estimate was reported by Mercer et al. (1982) for granular activated carbon treatment of Geokinetic retort water that had been treated by activated sludge. The estimated cost (1980) ranged from $\$ 2.25$ to $\$ 6.13 / 1000$ gal.

\section{WET AIR OXIDATION}

Wet air oxidation (WAO) is a thermal degradation process for oxidizing organic matter in aqueous liquid or semi-solid wastes. Oxidation is accomplished by exposing the waste to an oxygen source (usually air) under cond itions of elevated temperature and pressure. Typical pressures and temperatures are 500 to $3000 \mathrm{psi}$ and 150 to $320^{\circ} \mathrm{C}$. 


\section{Process Description}

A typical process flowsheet is shown in Figure 18 (Wi The Imi and Knopp 1979). Wastewater is brought to operating pressure using a high pressure pump. Air is compressed to the operating pressure and blended with high pressure wastewater. The combined wastewater-air mixture is heated by a heat exchanger and then injected to the reactor vessel where oxidation occurs. Effluent from the reactor is run through a heat exchanger, cooled, and separated into gas and liquid phases. The use of a heat exchanger is necessary since heat is liberated during the exothermic oxidation reaction. Generally, for wastes having a COD greater than approximately $10,000 \mathrm{mg} / 1$, enough heat is liberated from the oxidation reaction to bring the wastewater to the necessary operating temperature and no additional heat is required (Wi Thelmi and Knopp 1979).

For a given wastewater, the degree of oxidation obtained during WAO treatment depends upon the operating temperature and pressure and the reaction time. The typical effect of these variables on COD removal is shown in Figure 19. Generally, temperature and reaction time are chosen to achieve a desired leve 1 of treatment. An operating pressure is then chosen which is sufficiently greater than the vapor pressure of water at that temperature to prevent excessive evaporation losses. Excessively high pressures are avoided because of increased operating costs and safety considerations.

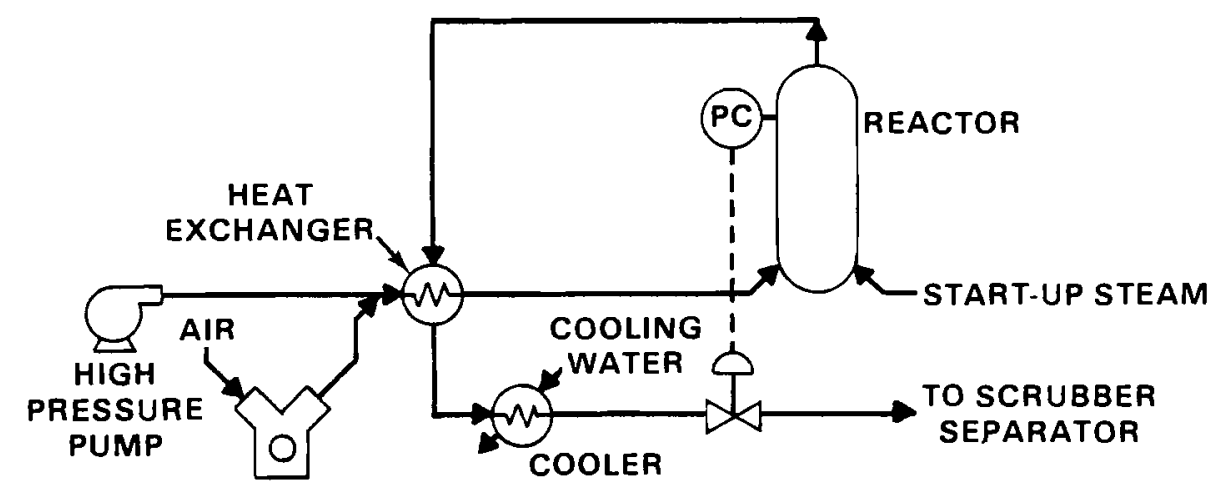

AIR COMPRESSOR

FIGURE 18. Basic Flowsheet of the Wet Air Oxidation Process 

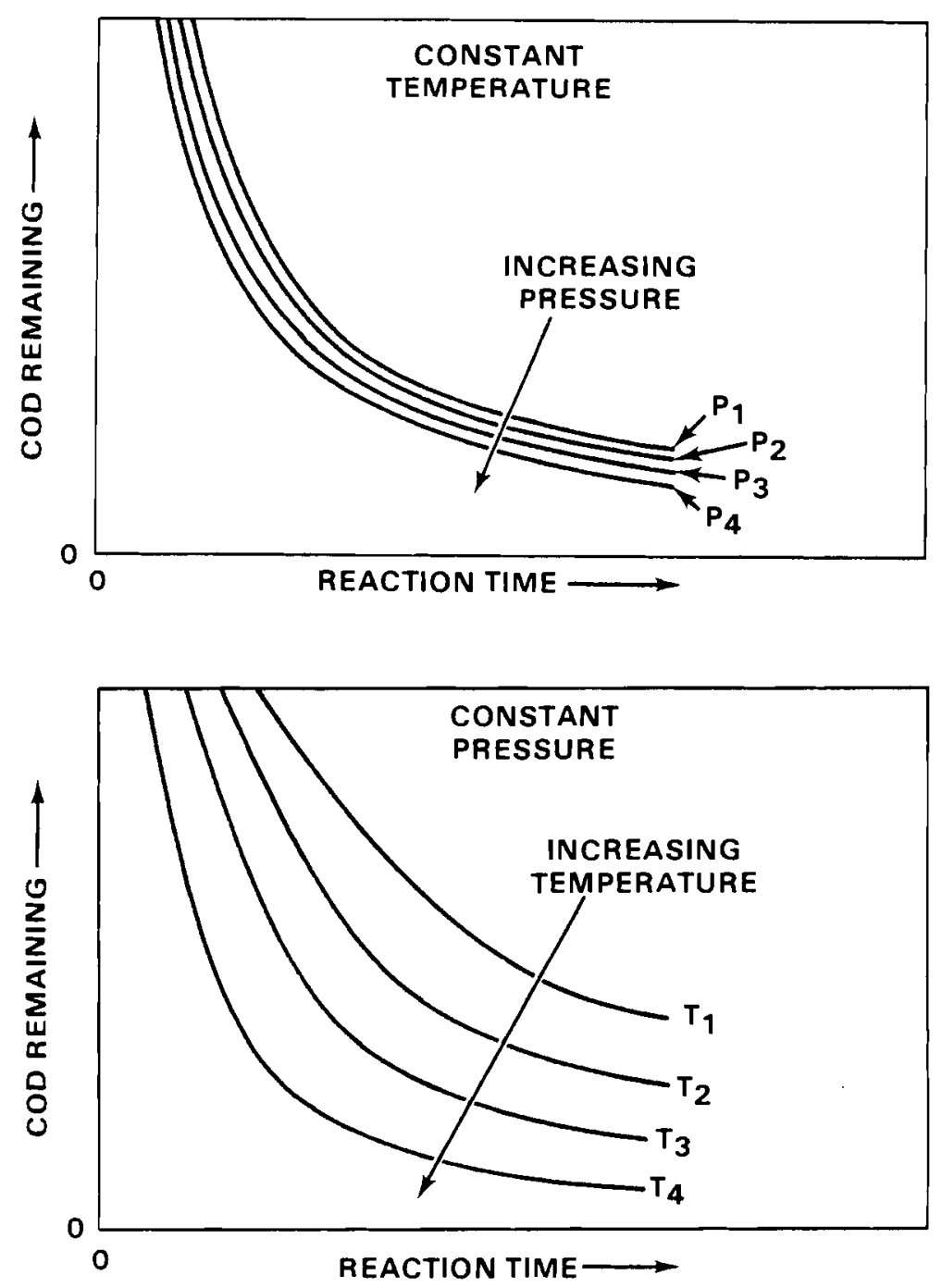

FIGURE 19. Effect of WAO Process Variables on COD Removal

Large organic molecules are degraded in a series of reactions during WOD. Initially, large high molecular weight organic compounds are partially oxidized to lower molecular weight intermediates such as aldehydes, alcohols, and fatty acids (Wilhelmi and Ely 1977). Generally, these initial reactions have low activation energies and proceed with relative ease. This is followed by an accumulation of lower molecular weight intermediates. Oxidation of these intermediates, in particular the carboxylic acids, requires high activation energy and is generally not possible under normal operating temperatures. 
Increasing reaction temperature, therefore, results more in an increase in the rate of $C O D$ reduction than in an increase in the total amount of COD consumed.

The characteristics of the WAO process suggest that it is a promising method for treating retort waters prior to wetting spent shale. The first favorable characteristic is the ability to handle high organic loadings. WAO is most appropriate for treating wastewaters too concentrated for biological treatment (COD greater than approximately $1000 \mathrm{mg} / 1$ ), yet too dilute to sustain combustion without in itial drying (COD less than approximately $300,000 \mathrm{mg} / 1)$. The COD's of oil shale retort waters typically fall within this range. Secondly, WAO is able to treat wastes containing toxic constituents and is able, in many cases, to detoxify these constituents (Wi lhelmi and Ely 1977). Many toxic organic molecules can be partially oxidized to innocuous low molecular weight intermediates. After application to the shale pile, these intermediates should be readily degradable by soil microorganisms in the shale piles. An expected desirable characteristic of WAO, though not yet proven, is the ability to easily oxidize reduced inorganic species. Oxidation of reduced sulfur species should be possible during WAO and would be advantageous since these constituents might prove obnoxious following application of retort waters to shale piles.

\section{Experimental Results}

Wet air oxidation tests were conducted with 1 gal Hastelloy $C$ autoclaves equipped with magnetically coupled stirrers. A schematic of the experimental apparatus is shown in Figure 20 . The tests were conducted with Paraho and Occidental (Retort 6) retort waters. The Paraho retort water was diluted 50\% with demineralized water to reduce the concentration of oxidizable material to an acceptable level for the tests. The tests were conducted at $250^{\circ} \mathrm{C}$ and $2000 \mathrm{psi}$. The results of these tests are presented in Tables 12 and 13 .

The large initial COD reduction for the 20-min time period is believed to be largely the result of rapid oxidation of thiosulf ate to sulf ate which produces one mole of sulfuric acid from each mole of sodium or ammonium thiosulfate present in the retort water. The $\mathrm{pH}$ of the Paraho water decreased from 8.65 to 1.62 during the initial $20 \mathrm{~min}$ and remained near the latter value for 


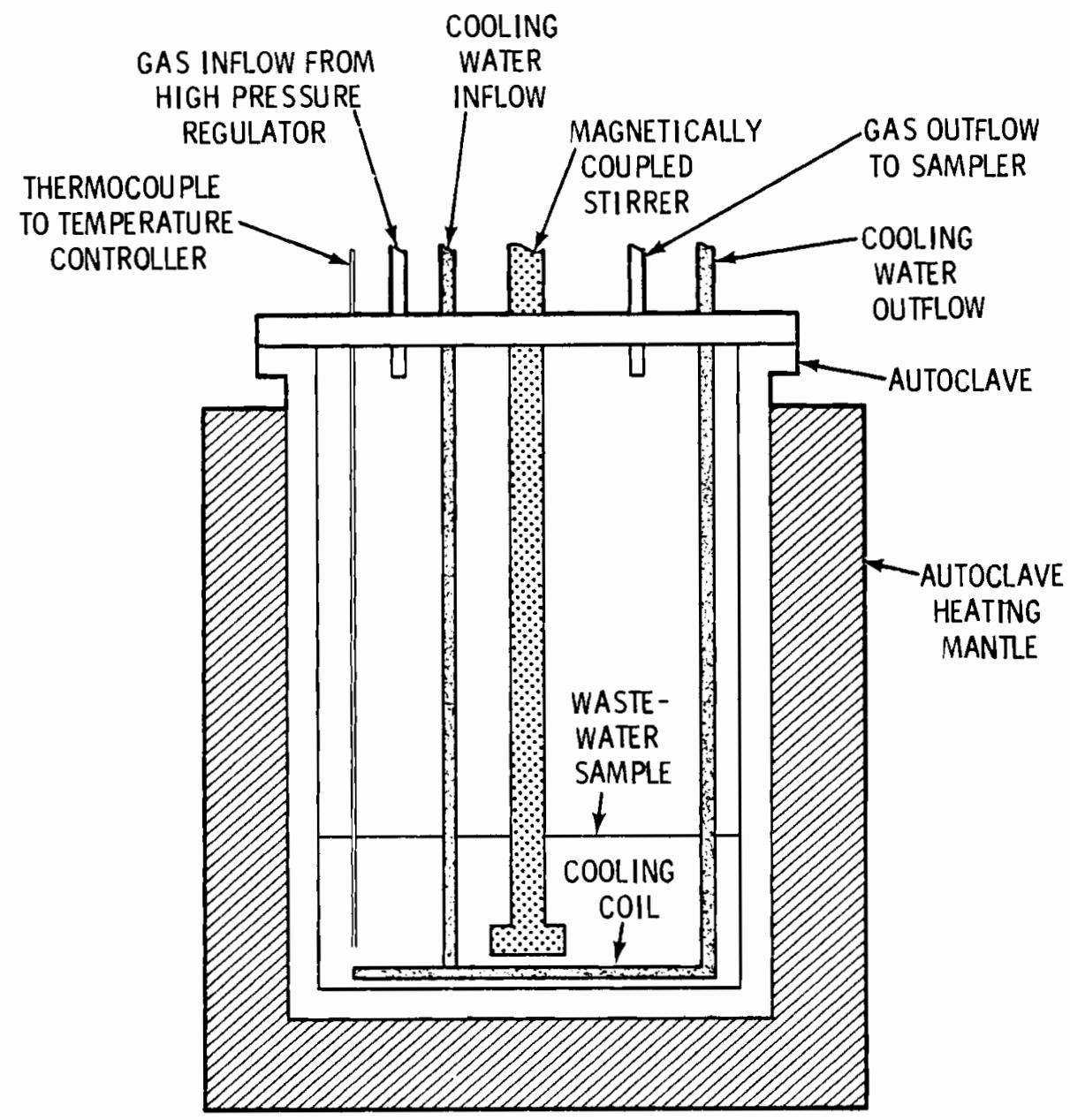

FIGURE 20. Laboratory Scale Wet Air Oxidation Apparatus

TABLE 12. COD and Suspended Solids Data for WAO Tests with Paraho Retort Water

Total

Suspended

\begin{tabular}{|c|c|c|c|}
\hline Camn & $\frac{\mathrm{CO}}{\mathrm{T}+\mathrm{T}}$ & $\frac{\mathrm{mg} / \mathrm{l}}{F^{\mathrm{i} g+r^{2}+0}}$ & Suspended \\
\hline Influent & 99,700 & 86,200 & 195 \\
\hline 20 min Effluent & 41,300 & 19,100 & 16,027 \\
\hline 30 min Effluent & 36,300 & 18,700 & 11,490 \\
\hline 40 min Effluent & 25,300 & 13,500 & 7,524 \\
\hline $60 \min$ Effluent & 23,700 & 12,500 & 7,385 \\
\hline 120 min Effluent & 16,700 & 8,700 & 5,709 \\
\hline
\end{tabular}


TABLE 13. COD and Suspended Solids Data for WAO Tests

with Occidental Retort 6 Water

\begin{tabular}{|c|c|c|c|}
\hline Sample & $\frac{C O}{\text { Total }}$ & $\frac{\mathrm{mg} / 1}{\text { Filtrate }}$ & $\begin{array}{c}\text { Tota } 1 \\
\text { Suspended } \\
\text { Solids, mg/l } \\
\end{array}$ \\
\hline Influent & 7,780 & 6,840 & 64.5 \\
\hline 30 min Effluent & $4 ; 450$ & 3,780 & 107 \\
\hline 120 min Effluent & 3,240 & 2,740 & 157 \\
\hline
\end{tabular}

the longer reaction time periods. Wet oxidation of the Paraho retort water not only reduced the total COD concentration, but also precipitated a substantial amount of COD. Approximately half of the COD could be filtered out of the treated retort water samples, which suggests the use of sedimentation/ filtration process for posttreatment of the effluent from a wet air oxidation unit.

REMOVAL OF HEAVY METALS AND SUSPENDED SOLIDS

Chemical precipitation and coagulation of steam stripped Geokinetics retort water and activated sludge treated retort was evaluated for heavy metals removal and suspended solids removal, respectively. The results of jar tests by this treatment method have been reported by Mercer et a1. (1982).

\section{Precipitation of Arsenic with Ferric Hydroxide}

Ferric hydroxide precipitation by addition of ferric chloride to steam stripped Geokinetics retort water was found to be effective for removing arsenic. Arsenic was reduced from $4.1 \mathrm{mg} / 1$ to less than $1 \mathrm{mg} / 1$ with $100 \mathrm{mg} / 1$ $\mathrm{Fe}^{+3}$ at $\mathrm{pH} 6$ or $100 \mathrm{mg} / 1 \mathrm{Fe}^{+}$with $32 \mathrm{mg} / 1 \mathrm{Mn}^{+2}$ or $\mathrm{Mn}^{+7}$ at $\mathrm{pH} 7.0$. Additional treatment of the same retort water did not reduce arsenic below $0.8 \mathrm{mg} / 1$ which indicates either a complex or organic form of arsenic not amenable to precipitation by this technique.

Heavy Metals and Boron in Treated Effluents

Effluents from various treatment steps in the bench scale studies were analyzed for elemental content by neutron activation and plasma emission spectroscopy. The results of these analyses for heavy metals and boron are 
presented in Tables 14 and 15 for Geokinetics No. 3 and 4 , respectively. An 80 to $84 \%$ reduction of As was achieved through the $\mathrm{Fe}^{+3}-\mathrm{Mn}^{+7}$ scavenging step, but little or no additional removal was achieved by activated sludge and activated carbon. Copper was reduced by a factor of 2.6 with $\mathrm{Fe}^{+3}-\mathrm{Mn}^{7}$ scavenging of steam stripped Geokinetic's retort water (Table 14). Removals were less than a factor of 2 for $B, C o$, and Mo. An increase in Mn was observed following the $\mathrm{Fe}^{+3}-\mathrm{Mn}^{+7}$ scavenging step, which is believed due to incomplete precipitation of the $\mathrm{Mn}$. The remaining metals, $\mathrm{Cd}, \mathrm{Fe}, \mathrm{Ni}, \mathrm{V}$, and $\mathrm{Zn}$, are either below or too near detection limits to determine removal levels.

Chemical Coagulation and Flocculation of Raw Retort Water

Only a limited number of chemical coagulation and flocculation tests were conducted on the retort water received at PNL because it is believed that comprehensive testing of this type should be conducted on fresh samples of retort water to assure reliable results. Retort water for these tests was obtained from the separator at the Geokinetic's facility rather than the holding basin to include a greater amount of $0 i 1$ in the retort water. The samples were taken near the $0 i 1 /$ water interface so these samples may not be entirely representative. Nevertheless some oil was included in the wastewater to observe how it would separate in the coagulation/flocculation tests.

Jar tests were conducted with $400 \mathrm{ml}$ of well-mixed retort water in oneliter beakers. Chemical coagulants and flocculants were added to the retort water and rapid mixing was carried out with paddle type stirrers for 3 min at 100 RPM. Rapid mixing was carried out by a 15-min flocculation period with the stirrers set at 40 RPM. The mixtures were then allowed to settle for $10 \mathrm{~min}$ or 30 min periods before sample aliquots were removed for suspended solids determinations. Table 16 presents results of the jar tests using polymers only. The results indicate that the cationic polymer may be superior to the neutral and anionic polymers although considerably more testing on fresh retort water would be requred to verify this observation and establish an optimal dos age. 
TABLE 14. Heavy Metals and Boron in Geokinetics No. 3 Effluents

\begin{tabular}{|c|c|c|c|c|c|c|c|c|c|c|c|c|c|c|}
\hline \multicolumn{15}{|c|}{ Concentration, ppm } \\
\hline Effluent & $\overline{A s}$ & $\underline{B}^{*}$ & $C d *$ & Co & $\mathrm{Cu}^{\star}$ & Fe & Mn & Mok & $\mathrm{Ni}$ & Sb & $\mathrm{Se}$ & $\mathrm{U}$ & $V$ & $\mathrm{Zn}$ \\
\hline Raw Retort Water & 4.1 & 108 & $<0.01$ & 0.37 & 0.33 & 8 & 0.2 & 8.4 & 0.8 & 0.13 & 0.30 & 0.11 & 0.15 & $<0.3$ \\
\hline Steam Stripper & 4.1 & 110 & $<0.01$ & 0.35 & 0.21 & 5 & 0.2 & 8.2 & 0.8 & 0.13 & 0.34 & 0.11 & $<0.08$ & $<0.3$ \\
\hline $\mathrm{Fe}^{+3}, \mathrm{Mn}^{+7}$ Scavenging & 0.8 & 71 & $<0.01$ & 0.35 & 0.08 & 5 & 2.0 & 7.7 & 1 & 0.08 & 0.26 & 0.09 & $<0.09$ & $<0.3$ \\
\hline Activated Sludge** & 0.6 & 107 & $<0.01$ & 0.40 & 0.10 & 5 & 2.0 & 7.1 & 0.7 & 0.08 & 0.18 & 0.04 & $<0.09$ & 0.5 \\
\hline 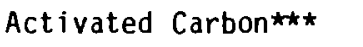 & 0.6 & 106 & $<0.01$ & 0.30 & $<0.01$ & 5 & 1.3 & 6.8 & 0.7 & 0.08 & 0.14 & 0.04 & $<0.08$ & $<0.3$ \\
\hline
\end{tabular}

* Determined by plasma emission spectroscopy. All others were determined by neutron activation.

$\star \star$ Alum clarified and filtered activated sludge effluent composite collected between day 40 and day 45 ( $F i g u r e ~ 11)$.

** Alum clarified and filtered activated sludge effluent composite sample treated with $4 \mathrm{~g} / 1 \mathrm{PAC}$ to give residual

$\mathrm{TOC}$ of $103 \mathrm{mg} / \mathrm{l}$ (see isotherm in Figure 16 ).

TABLE 15. Heavy Metals and Boron in Geokinetics No. 4 Effluents

\begin{tabular}{|c|c|c|c|c|c|c|c|c|c|c|c|c|c|c|}
\hline \multirow[b]{2}{*}{ Effluent } & \multirow{2}{*}{\multicolumn{13}{|c|}{ Concentration, ppm }} & \multirow[b]{2}{*}{$\mathrm{Zn}$} \\
\hline & & & $\mathrm{Cd}^{\star}$ & $\mathrm{Co}$ & $\bar{C} u^{\star}$ & $\mathrm{Fe}$ & $M n$ & $M^{\star} \star$ & $\mathrm{Ni}$ & Sb & $\mathrm{Se}$ & U & V & \\
\hline Raw Retort Water & 8.5 & 120 & $<0.01$ & 0.32 & 0.32 & 7 & 0.2 & 5.4 & 0.7 & 0.18 & 0.24 & 0.17 & $<0.08$ & 0.5 \\
\hline $\mathrm{Fe}^{+3}$, Mn Scavenging & 1.4 & 116 & $<0.01$ & 0.27 & 0.04 & 5 & 1.6 & 4.5 & 0.7 & 0.12 & 0.19 & 0.17 & $<0.08$ & $<0.3$ \\
\hline 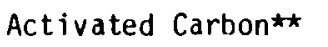 & 1.0 & 77 & $<0.01$ & 0.21 & $<0.01$ & 5 & 0.2 & 3.8 & 0.8 & 0.07 & 0.08 & 0.06 & $<0.09$ & $<0.3$ \\
\hline
\end{tabular}

* Determined by plasma emission spectroscopy. All others were determined by neutron activation.

** Effluent from activated carbon column at 165 bed volumes of previously biotreated and clarified effluent (see Figure 19). 
TABLE 16. Effect of Polymer Type and Dosage on Removal

of Suspended Solids from Retort Water(a)

\begin{tabular}{|c|c|c|}
\hline Polymer Type & Dosage, $\mathrm{mg} / 1$ & $\begin{array}{l}\text { Suspended Solids } \\
\text { After } 10 \mathrm{~min} \text { Settling, } \mathrm{mg} / 1\end{array}$ \\
\hline Anionic & 1.25 & 196 \\
\hline Anionic & 2.50 & 225 \\
\hline Anionic & 5.00 & 220 \\
\hline Neutral & 2.50 & 185 \\
\hline Neutra 1 & 5.00 & 218 \\
\hline Cationic & 5.00 & 136 \\
\hline Blank & 0 & 237 \\
\hline
\end{tabular}

(a) Geokinetics retort water aged $\sim 2$ weeks at ambient summertime temperatures.

The results of alum coagulation tests on Geokinetics retort water with suspended shale oil are presented in Table 17. Although the suspended solids results indicate some separation of suspended matter, none of the alum dosages produced a clarified liquor. These and other tests indicate a highly stable emulsion which is difficult to break without a pH change to the acid side. This $\mathrm{pH}$ change requires a rather costly acid addition because of the typically high alkalinity concentration in retort water. The lower alum dosages would appear to be useful for dissolved air flotation since the suspended matter tends to float with the alum floc.

Alum Coagulation of Biotreated Water

The results of the alum/polymer coagulation tests on Geokinetics retort water treated by activated sludge are presented in Table 18. A rapid settling floc was formed in all of the tests, however there was not a substantial improvement in nonfiltrable residue in any of the tests. Nonfilterable residue increased at 100 and $200 \mathrm{mg} / 1$ alum treatment which indicates incomplete flocculation. The $300 \mathrm{mg} / 1$ alum addition appeared to be about optimum for this series, therefore a single batch of $400 \mathrm{mls}$ of activated sludge effluent was treated with $300 \mathrm{mg} / 1$ alum and $1 \mathrm{mg} / 1$ of polymer as above, except the $\mathrm{pH}$ was maintained at 6.5 with $\mathrm{NaOH}$ addition. Filtration of this supernatant liquid 
TABLE 17. Alum Coagulation of Raw Geokinetics Retort Water

\begin{tabular}{|c|c|c|c|}
\hline \multirow[b]{2}{*}{ Alum Dosage } & \multicolumn{3}{|c|}{ Suspended Solids, $\mathrm{mg} / \mathrm{l}$} \\
\hline & $\begin{array}{l}\text { After } 10 \mathrm{~min} \\
\text { Settling } \\
\end{array}$ & $\begin{array}{c}\text { After } 30 \mathrm{~min} \\
\text { Settling } \\
\end{array}$ & Observations \\
\hline 0 & 199 & 159 & Appears homogeneous \\
\hline 50 & 132 & 94 & Floating matter \\
\hline 100 & 160 & 96 & Floating matter \\
\hline 250 & 191 & 99 & $\begin{array}{l}\text { Floating and } \\
\text { settled matter }\end{array}$ \\
\hline 500 & 126 & 92 & $\begin{array}{l}\text { Suspended and } \\
\text { settled matter }\end{array}$ \\
\hline 1000 & 69 & 81 & Settled matter only \\
\hline
\end{tabular}

TABLE 18. Results of Alum/Polymer Coagulation Tests on Biotreated Retort Water

\begin{tabular}{ccc}
$\begin{array}{c}\text { Alum Dosage, } \\
\mathrm{mg} / 1\end{array}$ & $\begin{array}{c}\text { Nonfilterable Residue, } \\
\mathrm{mg} / 1\left(103^{\circ} \mathrm{C}\right)\end{array}$ & $\frac{\mathrm{pH}}{6.50}$ \\
\cline { 1 - 2 } 0 & 69 & 6.50 \\
100 & 105 & 6.65 \\
200 & 118 & 5.13 \\
300 & 51 & 4.75 \\
400 & 53 & 4.46
\end{tabular}

through Whatman No. 1 filter paper, which roughly simulates rapid sand filtration, produced a filtrate with a nonfilerable residue $\left(103^{\circ} \mathrm{C}\right)$ of $18 \mathrm{mg} / 1$. This filtrate is expected to be sufficiently low in suspended solids to avoid frequent plugging of a granulated carbon bed although occasional backwashing may be necessary.

\section{EVAPORATION}

The results of laboratory and bench-scale evaporation tests on Geokinetics retort water have been reported by Wakamiya (1981). The purpose of this study was to determine the operating conditions and process variations associated with evaporation of oil shale retort water. The work was divided into two 
phases. Phase I was conducted to determine 1) the effectiveness of feed pretreatment relative to distillate quality; 2) the optimal degree of concentration; and 3) any potential operational problems such as fouling or foaming. Phase II was the actual evaporation test using a $95 \mathrm{l} /$ day bench-scale evaporator. The operating conditions for the evaporator were estimated in the Phase I tests. Operating data and analyses of samples taken during the operation of the evaporator were used to develop the process flows and energy costs for a proposed full-scale system.

Phase I - Laboratory Tests

The effectiveness of pretreatment was determined by evaporating pretreated and non-pretreated in situ retort water obtained from Geokinetics, Inc. Two methods of pretreatment evaluated were air sparging at 88 to $93^{\circ} \mathrm{C}$ and 1 ime treating with subsequent air sparging at ambient temperature. During the tests, influent, concentrate, and distillate samples were taken periodically for analysis. These analyses indicate that air sparging at 88 to $93^{\circ} \mathrm{C}$ was the most effective method. Lime pretreatment produced considerable amounts of sludge because of the high bicarbonate/carbonate content of the retort water and did not achieve superior ammonia removal. Glassware evaporation tests indicated that a concentration factor (CF) of 30 could be achieved. A CF between 20 and 25 was considered optimum for economic evaporator operation. Phase II - Bench-Scale Evaporator Test

A 95 1/day evaporator was operated continuously for a period of $136 \mathrm{hr}$ ( 5.6 days) after a sump concentration factor of 25 had been reached. The evaporator used was a vertical, flat plate, falling-film unit as shown in Figure 21. The feed entered through a filter and was heated to near boiling in a constant temperature bath. Evaporation occurred as the sump charge (5 1) was continuously recirculated over the outer surfaces of a $15 \mathrm{~cm}$ wide by $91 \mathrm{~cm}$ high by a $3.8 \mathrm{~cm}$ deep hollow pane 1 having $2730 \mathrm{~cm}^{2}$ of heat transfer surface $(0.157 \mathrm{~cm}$ thick titanium sheet). The rate of circulation was $30.3 \mathrm{l} / \mathrm{min}$. plant steam, fed to the inside of the panel through a pressure regulator, was the heat source for evaporation. The steam formed from evaporation of the concentrate was collected as distillate from a condenser. The heating steam 


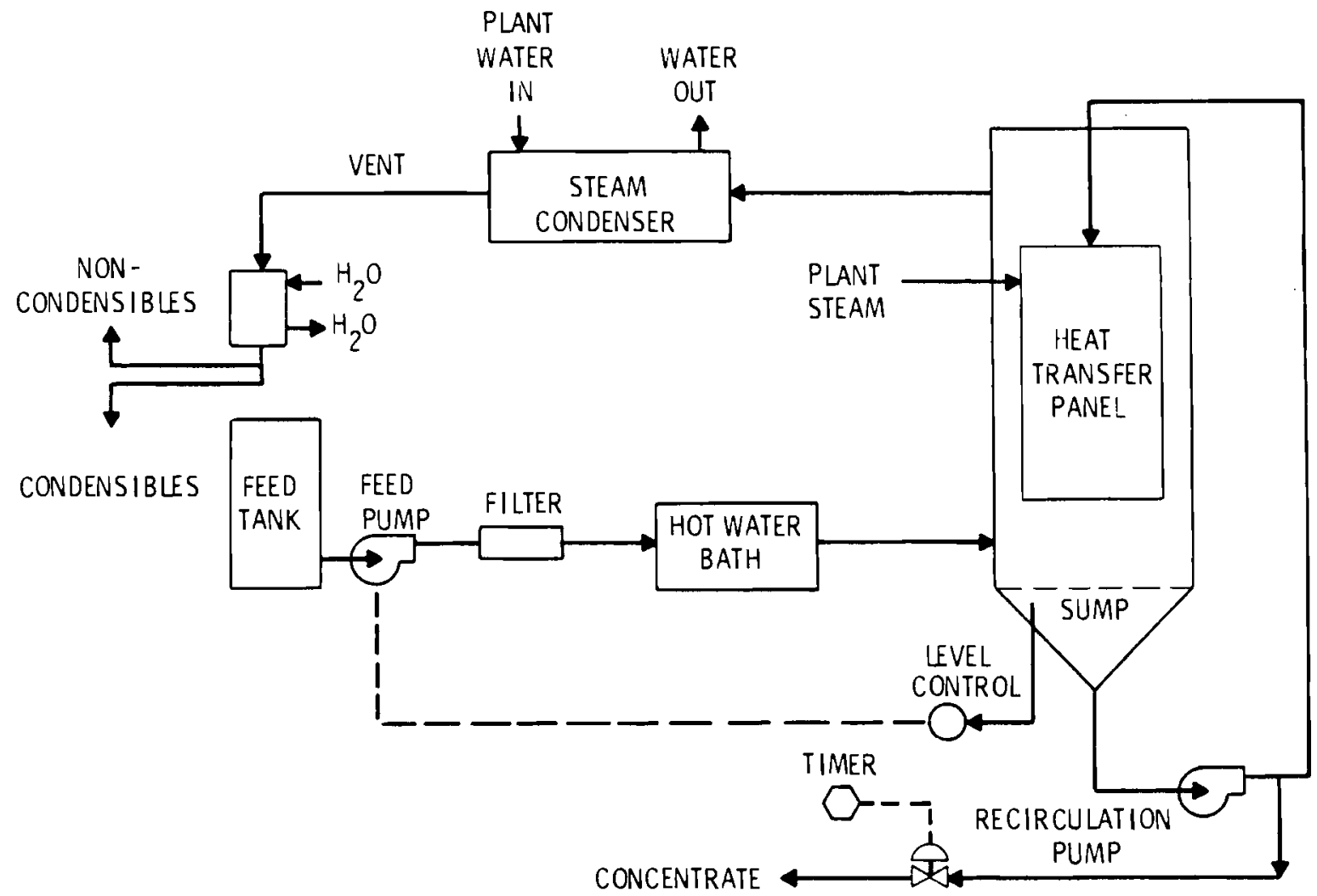

FIGURE 21. Diagram of Bench Scale Evaporator

pressure, sump pressure, ambient pressure, sump temperature, and distillate production rate were monitored continually during the above processing period.

The wastewater was pretreated by air sparging in 30 to 40 gal batches at $93^{\circ} \mathrm{C}$ before feeding to the evapoator. The period of sparging was determined by $\mathrm{pH}$ change. When $\mathrm{pH}$ remained constant after two successive readings taken a half hour apart, sparging was discontinued and the wastewater transferred to the evaporator feed tank. This normally occurred around a pH of 10.

The average composition of the evaporator inputs and outputs during the five days of continuous operation are given in Table 19. The overall heat transfer coefficient across the evaporator pane 1 was $2610 \mathrm{~J} / \mathrm{m}^{2} \mathrm{~s} \cdot{ }^{\circ} \mathrm{K}$ and the temperature difference between steam and evaporating liquid was $4.6^{\circ} \mathrm{C}$. Heat transfer remained relatively constant during the 1 ast $72 \mathrm{hr}$ of operation. There was slight foaming of the sump concentrate while evaporating to a CF of 
TABLE 19. Average Composition of Bench Model Evaporator Inputs and Outputs During Five Days of Continuous Operation

\begin{tabular}{|c|c|c|c|c|}
\hline Constituents & $\begin{array}{l}\text { Feed as } \\
\text { Received }\end{array}$ & $\begin{array}{l}\text { Feed, } 200^{\circ} \mathrm{F} \\
\text { A ir Sparged }\end{array}$ & Condensate & $\begin{array}{c}\text { Sump } \\
\text { Concentrate }\end{array}$ \\
\hline $\mathrm{NH}_{3}$ & 1,620 & 176 & 224 & -- \\
\hline Conductivity $(\mu \mathrm{mhos} / \mathrm{cm})$ & 17,830 & 16,100 & 1,260 & 437,000 \\
\hline $\mathrm{pH}$ & 9.0 & 9.9 & 7.4 & 10.4 \\
\hline Total Inorganic Carbon & 2,390 & 1,380 & 162 & 17,200 \\
\hline Total Organic Carbon & 1,830 & 2,050 & 549 & 42,300 \\
\hline Total Residue, $103^{\circ} \mathrm{C}$ & 15,300 & 19,300 & 34 & 446,700 \\
\hline Total Volatile Residue & 2,580 & 3,850 & 21 & 98,100 \\
\hline \multicolumn{5}{|l|}{ Total Nonfil terable } \\
\hline Residue, $103^{\circ} \mathrm{C}$ & 148 & 157 & 1 & 3,460 \\
\hline \multicolumn{5}{|l|}{ Volatile Nonfilterable } \\
\hline Residue & 103 & 92 & -- & 800 \\
\hline Alkalinity $\left(\mathrm{CaCO}_{3}\right)$ & 11,920 & 9,380 & 666 & 105,000 \\
\hline Concentration $\mathrm{Factor}$ & -- & 1.4 & -- & 29.1 \\
\hline $\mathrm{Na}^{+}$ & 5,830 & 7,080 & 1.1 & 105,000 \\
\hline $\mathrm{Mg}^{++}$ & 7.0 & 8.9 & 0.1 & 16.9 \\
\hline $\mathrm{Ca}^{++}$ & 5.2 & 5.8 & 1.3 & 5.2 \\
\hline COD & 7,150 & 7,850 & 1,820 & -- \\
\hline Arsenic & 21.7 & -- & 0.13 & 510 \\
\hline
\end{tabular}

Note: A1l values in $\mathrm{mg} / 1$ except as noted.

10, but beyond that the foaming was negligible. Inspection of the heat transfer pane 1 after shutdown of the unit disclosed a uniform chocolate-brown $\mathrm{fi} \mathrm{lm}$ estimated to be less than $0.003 \mathrm{~cm}$ thick. Rinsing of the panel, after reinstallation in the evaporator, with $5 \%$ sulfuric ac id at $88^{\circ} \mathrm{C}$ recirculating at $30.31 / \mathrm{min}$ removed the coating in $1.5 \mathrm{hr}$.

\section{Fu11-Scale System Concept}

A system concept for evaporating shale oil retort water and recovering ammonia as ammonium sulfate was developed based on the laboratory tests and 
the bench-scale evaporation tests. This system was designed to process retort water from an in situ facility producing $7950 \mathrm{~m}^{3}$ (50,000 barrels) of oil per day. This conceptual process design is detailed in figure 22. The mass flows and temperatures of the streams are shown in Table 20. In this process, retort water is preheated to an ammonia stripping tower input temperature of $93^{\circ} \mathrm{C}$ by counter-current heat exchange with the distillate produced by the evaporator. The vent from the evaporator system is blended with makeup steam to provide the required amounts for stripping ammonia in the packed tower.

The steam and ammonia from the stripping tower is condensed in the presence of sulfuric acid. The resulting solution of ammonia sulfate is then concentrated to about $48 \mathrm{wt} \%$ by evaporation. If further concentration or drying is desired, the evaporator concentrate can be fed to a drying system. The ammonium sulfate could be marketed in solution form or dried as a standard commercial bulk form.

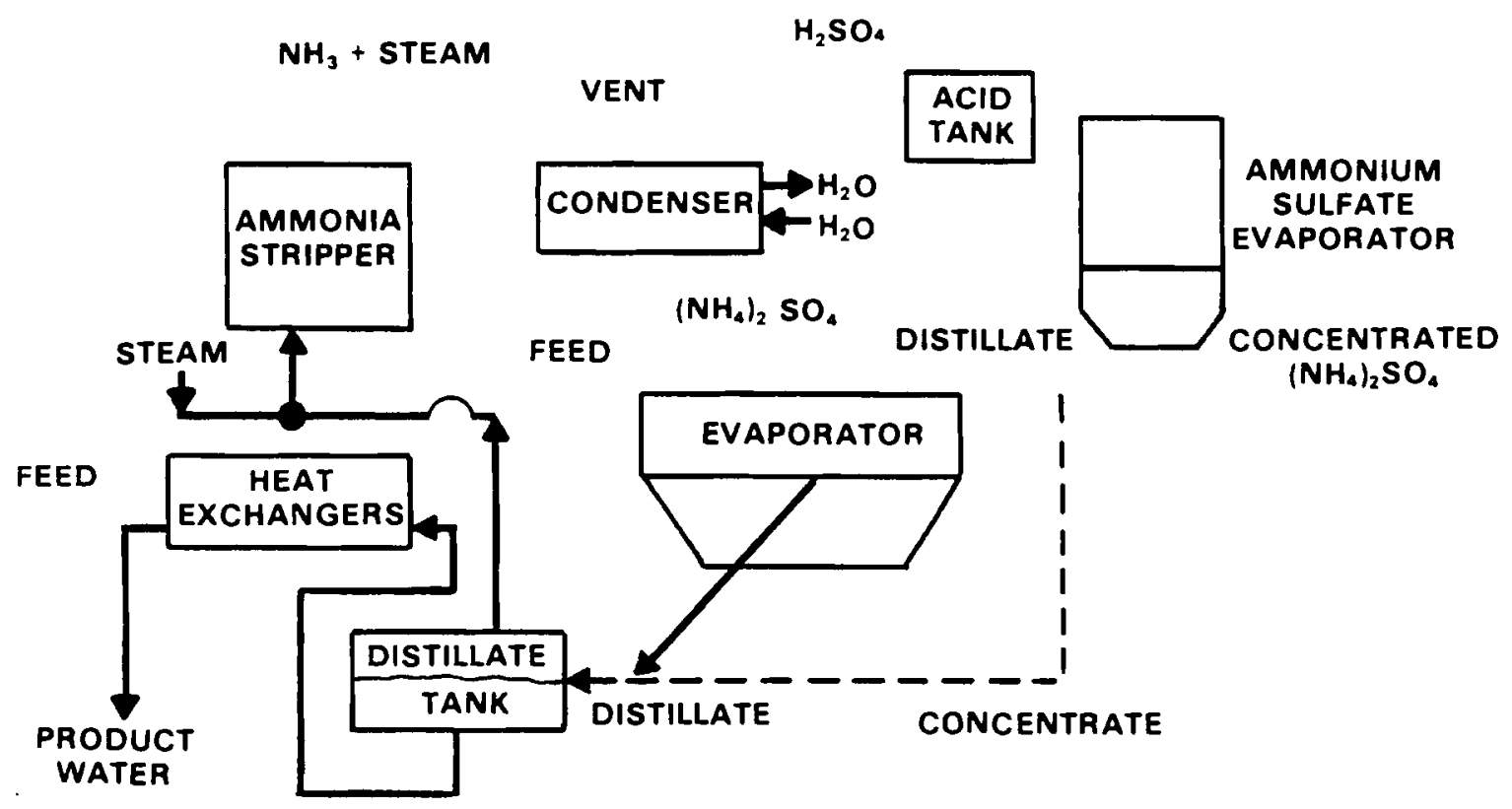

FIGURE 22. Conceptual Process Design 
TABLE 20. Process Flow Rates and Temperatures

\begin{tabular}{|c|c|c|}
\hline Description & $\begin{array}{l}\text { Flow Rate } \\
\mathrm{kg} / \mathrm{min}\end{array}$ & $\begin{array}{l}\text { Temperature } \\
{ }^{\circ} \mathrm{C} \\
\end{array}$ \\
\hline Tota 1 Feed & 5,342 & 16 \\
\hline Feed to Evaporator & 5,400 & 97 \\
\hline Distillate from Evaporator & 5,076 & 104 \\
\hline Total Product Water & 5,136 & 24 \\
\hline Concentrate & 324 & 101 \\
\hline Makeup S team & 166 & 104 \\
\hline Steam from Vent & 137 & 104 \\
\hline Steam to Stripper & 303 & 104 \\
\hline Ammonia and Steam & 244 & 97 \\
\hline Condensed $\left(\mathrm{NH}_{4}\right)_{2} \mathrm{SO}_{4}$ Solution & 273 & 93 \\
\hline Acid to Condenser $\left(66^{\circ} \mathrm{Be} \mathrm{H}_{2} \mathrm{SO}_{4}\right)$ & 29 & 16 \\
\hline Distillate from $\left(\mathrm{NH}_{4}\right)_{2} \mathrm{SO}_{4}$ Evaporator & 197 & 107 \\
\hline Concentrate $\left(\mathrm{NH}_{4}\right)_{2} \mathrm{SO}_{4}$ to Dryer & 76 & 101 \\
\hline Ammonium Sulfate, Dry Basis & 37 & - \\
\hline Dryer Vent & 39 & - \\
\hline
\end{tabular}

The estimated cost breakdown for this full-scale is summarized below.

Capita 1

Equipment

Engineering (15\% of Capital Equipment)

$\$ 6,000,000$

Insta 11 ation (75\% of Capital Equipment)

900,000

Total Capital

$4,500,000$

$\$ 11,400,000$

Operation and Maintenance, $\$ / \mathrm{yr}$

Labor ( $\$ 10 / \mathrm{hr}, 2 \mathrm{hr} / \mathrm{d})$

7,000

Acid $(29 \mathrm{~kg} / \mathrm{min}, \$ 66 / \mathrm{t})$

$1,010,000$

Thermal Energy (Steam) (\$9.69/1000 kg)

850,000

Electrical Energy ( $\$ 0.03 / \mathrm{KWh})$

$2,820,000$

Maintenance ( $4 \%$ of Capital Equipment)

240,000

Total 0\&M

$\$ 4,927,000$ 
Amortization, $\$ / y r$

(e) $12.5 \%$ per $20 \mathrm{Yr}$, CFR $=0.138$

$\$ 1,573,000$

Total Annual Operation Cost

$6,500,000$

Amonium Sulf ate Credit, $\$ / y r$

a 53 ton/day and $\$ 66 /$ ton

$1,280,000$

Cost per 1000 Gallons of Wastewater

Without $\left(\mathrm{NH}_{4}\right)_{2} \mathrm{SO}_{4}$ Cred it $\quad 8.52$

With $\left(\mathrm{NH}_{4}\right)_{2} \mathrm{SO}_{4}$ Credit $\quad 6.78$

The above costs compare favorably with the cost for physical/chemical and biological treatment which was estimated to be in the range of $\$ 10.78$ to $\$ 24.75 / 1000$ gal by Mercer et al. (1982).

Disposal or Reuse of Evaporator Product Streams

The condensate from evaporation of the retort water is not suitable for discharge to surface receiving water due to the residual COD and ammonia concentrations. It may be used without further treatment, however, for irrigation purposes and steam generation for injection into modified in situ retorts where ammonia and organics can be tolerated. Reuse as irrigation water would require verification in field tests to determine if a residual organic carbon concentration of $500 \mathrm{mg} / 1$ is harmful to crops.

Bench-scale studies on biological and activated carbon treatment of the retort water evaportor condensate were conducted to evaluate the effectiveness of these processes for improving the quality of this water. Biological treatment by activated sludge was effective for removing between 35 and $45 \%$ of the total organic carbon (TOC) and chemical oxygen demand (COD). The TOC and COD removal levels were near $35 \%$ at a solids retention time of 15 days in the activated sludge units, and were near $45 \%$ at a solids retention time of 30 days. The hydraulic retention time was $8 \mathrm{hr}$ in each case. Greater than 99\% removal of TOC was achieved with combined activated sludge and activated carbon treatment to breakghrough at 100 bed volumes of carbon column effluent. Greater than $98.4 \%$ TOC removal was achieved with activated carbon adsorption alone to breakthrough at 90 bed volumes of carbon column effluent. 
The possibility of using retort water concentrate as a source of makeup for the Kraft wood pulping process was considered. Salt cake or sodium sulfate is the conventional makeup salt for this process but sodium carbonate can also be used and may be preferred at many pulp mills. In situ retort water concentrate is largely composed of sodium carbonate and sodium sulfate. The organic matter in the retort water would be incinerated along with black liquor in the Kraft pulping process.

Crystallization experiments were conducted on concentrated Geokinetics retort water to evaluate: 1) potential for recovery of soda ash; 2) reduction of waste salt volume for disposal; 3) upgrading the fuel value of concentrated residue for incineration. In-situ retort waters typically contain high concentrations of dissolved salts and organic matter which tend to interfere with conventional biological and physical/chemical treatment processes. Evaporation has been identified as one of the more promising methods of treating this waste because of the relatively high quality of the water recovered and the small quantity of residue (evaporator concentrate) produced. Incineration of the residue to destroy the organic matter is one of the disposal options being considered for this waste. The high concentrations of inorganic bicarbonate and sodium sulfate generally reduce the calorific content of the residue from in-situ retort water below 5000 Btu/lb of dry solids needed to sustain combustion without additional fuel in an incinerator. A gross calorific value of 2000 Btu/lb of dry solids was measured for a sample of evaporator concentrate produced from a Geokinetics retort water. Based on the composition of the evaporator sump concentrate (see Table 18), 30\% of the sodium would be associated with carbonate/bicarbonate. Material balance calculations indicate some of the sodium ( $12 \%$ ) may have already crystallized from the sump concentrate before sampling.

Another sample of the same Geokinetics retort water used previously in the bench-scale evaporation study was evaporated from 1301 to 7.651 in open beakers (concentration factor 17:1). At this concentration, little or no crystallization or precipitation was observed. Results of analys is of this concentrated retort water are given in Table 21. 
TABLE 21. Results of Analysis of Geokinetics Retort Water Concentrate

Constituent

$$
\mathrm{Na}^{+}, \mathrm{g} / 1
$$

As, $g / 1$

Inorganic Carbon, $g / 1$

Organic Carbon, g/l

Alkalinity to $\mathrm{pH} 7.7^{(\mathrm{a})}, \mathrm{g} / 1 \mathrm{CaCO}_{3}$ Alkalinity to $\mathrm{pH} 3.7^{(\mathrm{a})}, \mathrm{g} / 1 \mathrm{CaCO}_{3}$ $\mathrm{SO}_{4}, \mathrm{~g} / 1$

$\mathrm{Cl}^{-}, \mathrm{g} / 1$

$\mathrm{SCN}^{-}, \mathrm{g} / 1$

$\mathrm{S}_{2} \mathrm{O}_{3}, \mathrm{~g} / 1$

$\mathrm{pH}$, un its

\section{Concentration}

100

0.32

23

32

50

138

19

4.7

6.2

39

9.8

(a) Inflection points in titration curve

Based on a pH of $9.8, \sim 25 \%$ of the inorganic carbon exists as $\mathrm{CO}_{3}=$, and $75 \%$ as $\mathrm{HCO}_{3^{-}}^{-}$. At this ratio, the sodium equivalent of $23 \mathrm{~g} / 1$ of inorganic carbon is $55 \mathrm{~g} / 1$; therefore, a maximum of about $55 \%$ of the sodium is recoverable as soda ash $\left(\mathrm{Na}_{2} \mathrm{CO}_{3}\right)$. Accurate computation of carbonate/ bicarbonate concentrations from alkalinity values is not possible because of the presence of buffering agents in the retort water.

Two approaches were used to crystallize sodium carbonate or bicarbonate from the retort water concentrate. The first involved successive evaporation of the concentrated solution or filtrates to smaller volumes followed by overnight crystallization then separation of the crystals by filtration the next day. The second approach also involved successive evaporations but included additional treatment of the original concentrate and subsequent filtrates with $\mathrm{CO}_{2}$ to produce sodium bicarbonate, which is less soluble than sodium carbonate. Evaporation of the concentrate to $\sim 30 \%$ of its original volume resulted in substantial crystallization of sulfate. Comparisons of results from two experiments with and without $\mathrm{CO}_{2}$ treatment are presented in Table 22 . 
TABLE 22. Comparison of Results from Crystallization with and Without Carbon Dioxide

\begin{tabular}{|c|c|c|}
\hline Parameter & $\begin{array}{l}\text { Without } \\
\mathrm{CO}_{2}\end{array}$ & $\begin{array}{l}\text { With } \\
\mathrm{CO}_{2}\end{array}$ \\
\hline $\begin{array}{l}\text { Original volume of concentrate, } \mathrm{ml} \\
\text { Number of crystallization }\end{array}$ & $3^{(a)}$ & 1000 \\
\hline Final volume of concentrate, $\mathrm{ml}$ & 300 & 300 \\
\hline Weight of $\mathrm{Na}$ recovered, $\mathrm{g}$ & 28 & 31 \\
\hline Available soda ash rcovered, $\%$ & 51 & 56 \\
\hline
\end{tabular}

(a) Evaporated to 600,400 , and $300 \mathrm{ml}$.

(b) Treated with $\mathrm{CO}_{2}$ at 1000,600 , and $300 \mathrm{ml}$.

Analytical data indicate that about one-third of the organic carbon was lost in evaporation of 11 of concentrate to $300 \mathrm{ml}$ and the crystallized product may be contaminated with more arsenic ( $800 \mathrm{ppm})$ than can be accounted for by residual liquid not removed from the filter cake of crystals. No rinses were employed in these studies.

The results of the crystallization studies indicate that recovery of soda ash is possible from retort water concentrate, but the loss of organic carbon during the evaporation step offsets most of the potential gain in the fuel value of the residue.

Fixation experiments were also conducted to determine arsenic leaching from mixtures of asphalt or sulfur or a combination of these two fixation agents with the dry residue from evaporation of Geokinetics retort water. The retort water was evaporated to dryness at $103^{\circ} \mathrm{C}$ and ground to a fine powder. The powder was then thoroughly blended with the fixation agent $(\mathrm{s})$ at $120^{\circ} \mathrm{C}$ then cast into cylinders $3.3 \mathrm{~cm}$ in diameter and weighing at least $100 \mathrm{~g}$. A polypropylene mold was used to form the cylinders of fixed waste. Road asphalt, $M C-800$, was treated by heating at $160^{\circ} \mathrm{C}$ for two days to remove the kerosine solvent before blending with the waste residue. Sulfur was used in the form of a sublimed powder (sulfur flowers). The cylinders of fixed waste were subjected to the "Structural Integrity Procedure" and the "EP Toxicity Test" as detailed in 40 CFR, Part 261 of the Federal Register published May 18, 
1980. These tests were developed by the EPA for evaluating potentially hazardous wastes under RCRA. Structural integrity is determined by dropping a $0.3 \mathrm{~kg}$ weight a distance of $15.25 \mathrm{~cm}$ fifteen times on a test sample of the waste in a compaction tester built to EPA specifications. The material remaining in the tester is removed and used for the EP toxicity test which consists of contacting the material in 16 times the test sample's weight in water controlled at $\mathrm{pH} 5.0 \pm 0.2$ with acetic acid for $24 \mathrm{hr}$ at $20^{\circ} \mathrm{C}$ to $40^{\circ} \mathrm{C}$. A solution $0.5 \mathrm{M}$ acetic acid was added with a modified automatic titrator as needed to control the $\mathrm{pH}$ within the prescribed limits. The cylinders of waste were suspended in the water by means of teflon coated wire to assure good contact with the stirred acetate solution.

The cylinders of waste used in these tests remained in one piece after the Structural Integrity Procedure except for a few small chips $(0.2 \mathrm{gm})$ off the $500 \%$ waste $-50 \%$ sulfur mixture. At the completion of the leaching period, sufficient deionized water was added to dilute the solution to 20 times the weight of the test sample. The diluted solution was mixed and aliquots taken for arsenic analysis. The results of the EP Toxicity Test are given in Table 23.

Arsenic concentrations in Table 23 are less than the $5.0 \mathrm{mg} / 1$ limit prescribed by EPA which indicates that fixation with asphalt or sulfur or mixtures thereof has potential for rendering retort water evaporator residues nonhazardous with respect to arsenic, the major toxic heavy heavy metal in Geokinetics retort water.

TABLE 23. Results of EP Toxicity Test

Arsenic in Dry Residue $=4900 \mathrm{ppm}$

\begin{tabular}{|c|c|c|c|}
\hline Sample & $\begin{array}{c}\text { Sample } \\
\text { Weight, } g\end{array}$ & $\begin{array}{l}\text { Volume of } \\
\text { Acitic Acid } \\
\text { Added, ml } \\
\end{array}$ & $\begin{array}{c}\text { Arsenic } \\
\text { Concentration } \\
\text { in solution, } \mathrm{mg} / \mathrm{l} \\
\end{array}$ \\
\hline $60 W-40 A^{*}$ & 100 & 141 & 2.0 \\
\hline $60 \mathrm{~W}-30 \mathrm{~A}-105$ & 100 & 74 & 1.0 \\
\hline $50 W-505$ & 111 & 148 & 1.7 \\
\hline
\end{tabular}




\section{MINEWATER TREATMENT}

Water pumped from underground oil shale mines or in situ operational zones in an oil shale formation may contain pollutants, such as fluoride, boron, and high dissolved salt concentrations, which will prevent unrestricted release of this water to surface receiving streams.

\section{ACTIVATED ALUMINA SORPTION AND ION EXCHANGE}

Treatability studies were conducted to evaluate ion exchange methods for fluoride and boron removal from a ground-water sample taken from an oil shale formation on the CA Tract in Colorado. Activated alumina was investigated for fluoride removal, and a boron selective ion exchange resin (Amberlite XE-243 ${ }^{(\mathbb{B})}$ was investigated for boron removal. Breakthrough curves for fluoride and boron are given in Figure 23. Anticipated discharge limits for fluoride and boron are $2 \mathrm{mg} / 1$ and $0.3 \mathrm{mg} / 1$, respectively; therefore, the volume capacity for fluoride removal is about 350 bed volumes, whereas the capacity for boron removal is about 10,000 bed volumes. Estimated chemical regenerant costs for fluoride and boron removal are $\$ 0.30$ and $\$ 0.01 / 1000$ gal of water treated, respectively.

CHEMICAL TREATMENT FOR FLUORIDE REMOVAL

Results of precipitation experiments with simulated oil shale ground water indicate $90 \%$ fluoride removal with phosphoric acid and lime addition. Approximately 9 moles of phosphorus and 10 moles of calcium per mole of fluoride are required to achieve this level of fluoride removal, which would be needed to meet discharge limits. The precipitate formed is basically a mixture of fluorapatite, $\mathrm{Ca}_{5} \mathrm{~F}\left(\mathrm{PO}_{4}\right)_{3}$, and hydroxyapatite, $\mathrm{Ca} a_{5}(\mathrm{OH})\left(\mathrm{PO}_{4}\right)_{3}$. The cost of phosphoric acid and lime to treat the ground water is estimated to be about $\$ 2 / 1000 \mathrm{gal}$, which is excessive relative to activated alumina sorption.

\footnotetext{
(8) Trademark of the Rohm and Haas Company, Philadelphia, PA.
} 


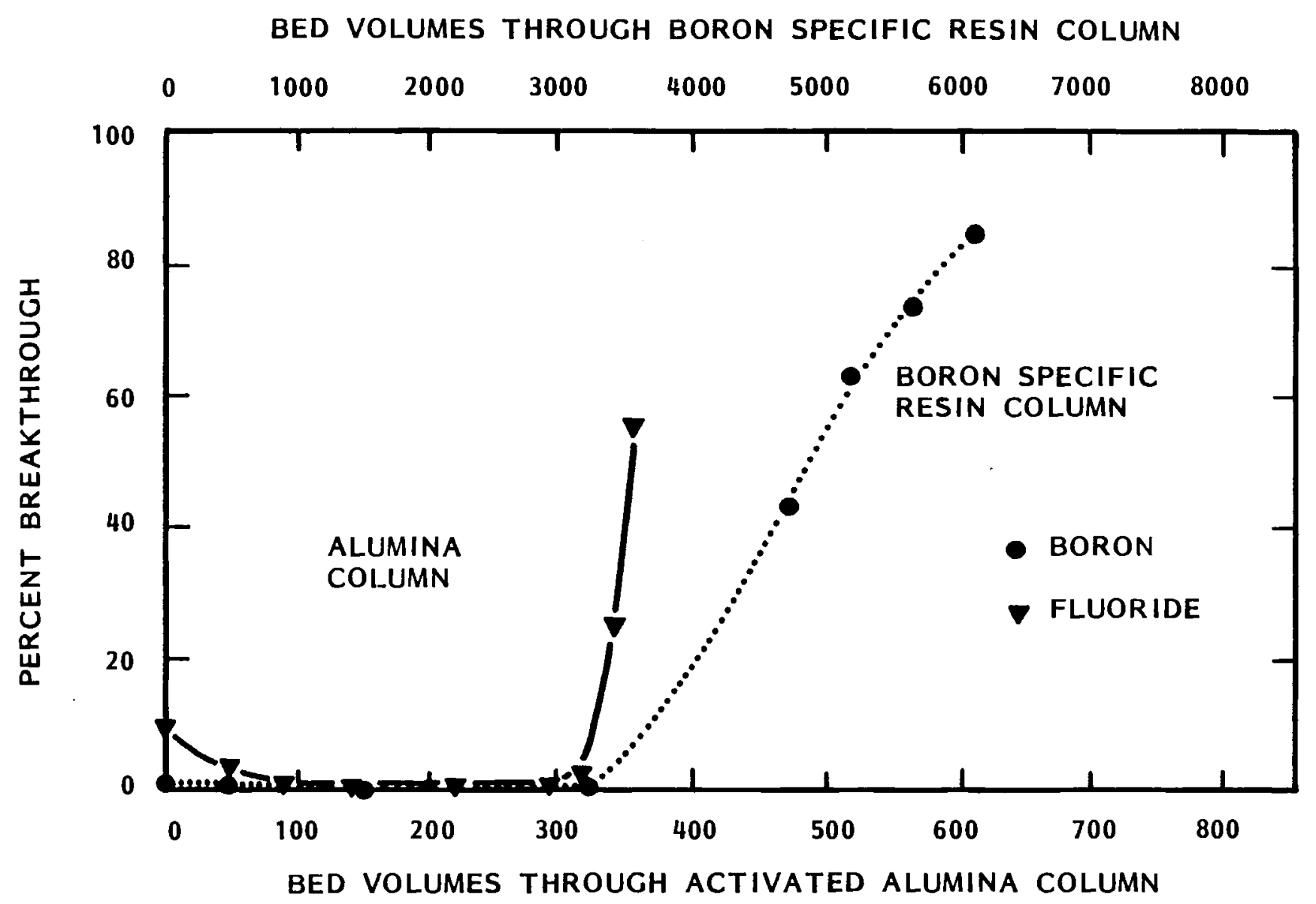

FIGURE 23. Fluoride and Boron Breakthrough Curves Influent $B=7.0 \mathrm{mg} / \mathrm{l}, F=20 \mathrm{mg} / \mathrm{l}$ 


\section{REFERENCES}

Brown, W. V. 1963. "Economics of Recovering Acetic Acid." Chem. Eng. Proc., Vol. 59, No. 10, pp. 65-68.

Earhart, J. P. et al. 1976. Extraction of Chemical Pollutants from Industrial Wastewaters with Volatile Solvents. EPA 600/2-76-220.

Farrier, D S., J. E. Virgona, T. E. Phillips and R. E. Poulson. 1978. "Environmental Research for In-Situ $0 i l$ Shale Processing. Proceedings of the 11th 0il Shale Symposium, Colorado School of Mines, Golden, CoTorado.

Fox, J. P., D. S. Farrier and R. E. Poulson. 1978. "Chemical Characerization and Analytical Considerations for an In Situ $0 i 1$ Shale Process Water." U.S. Department of Energy, Laramie Energy Technology Center Report of Investigations, Laramie, Wyoming.

Fox, J. P., and T. E. Phillips. 1980. Water Management Strategies--Issues and Research Needs. Paper presented at the Conference on Oil Shale, the Environmental Challenges, August 11-14, Vail, Colorado.

Greminger, D. C. 1979. Extraction of Phenols from Coal Conversion Process Condensate Waters. M.S. Thes is in Chemical Engineering, University of California, Berkeley, June. Also Lawrence Berkeley Laboratory Report LBL-9177.

Hanson, C. 1968. "Solvent Extraction: Theory, Equipment, Commercial Operations, and Economics." Chem. Eng., August 16, p. 97.

Helse1, R. W. 1978. "Removing Carboxylic Acids from Aqueous Wastes." Chem. Eng. Prog., May, pp. 55-59 (Also reported in Lyman 1978).

Hicks, R. E., R. F. Probstein, I. Wei, D. S Farrier, J. Latwala and T. E. Philips. 1980. "Wastewater Treatment and Management of $0 i 1$ Shale Plants." Proceedings of the 13th 0il Shale Symposium, Colorado School of Mines, Golden, Colorado.

Kiezyk, P. R., and D. Mackay. 1971. "Wastewater Treatment by Solvent Extraction." Can. J. Chem. Eng., Vol. 49, pp. 747-752.

Lorton, G. A. 1977. Removal of Phenols from Process Condensate. C. F. Braun and Company, Report FE-2240-39. Prepared for the Department of Energy and Gas Research Institute.

Lyman, W. J. 1978. "Liquid-Liquid Extraction of Organics." In: Unit Operation for Treatment of Hazardous Industrial Wastes. J. B. Berkowitz et a T., pp. 680-709. Noyes Data Corporation, Park Ridge, New Jersey. 
Mercer, B. W., A. C. Campbell and W. Wakamiya. 1979. Evaluation of Land Disposal and Underground Injection of Shale 011 Wastewaters. PNL-2596, Pacific Northwest Laboratory, Richland, Washington.

Mercer, B. W., M. J. Mason, R. R, Spencer, A. L. Wong and W. Wakamiya. 1982. "Evaluation of Physical-Chemical and Biological Treatment of Shale 0il Retort Water." PNL-3449, Pac if ic Northwest Laboratory, Richland, Washington.

Parsons, W. A., and W. Nolde. 1977. "Applicability of Coke Plant Water Treatment Technology to Coal Gasification." Symposium Proceedings: Enviromental Aspects of Fuel Conversion Technology III, pp. 519-527, Hollywood, Florida (A1so EPA 600/7-78-063).

Riley, R. G., T. R. Garland, K. Shiosaki, D. C. Mann and R. E. Wildung. 1981. Alkylpyridines in Surface Waters, Ground Waters, and Subsoils of a Drainage Loc ated Adjacent to an $0 i 1$ Shale Facility. Environ. Sci. Technol. 15: $697-701$.

Snyder, L. R. 1974. "Class ification of the Solvent Properties of Common Liquids." J. Chromatography 92:223-230.

Treybal, R. E. 1966. "Liquid Extractor Performance." Chemical Engineering Progress 62,9 .

Wakamiya, W. 1981. "Shale 0il Wastewater Treatment by Evaporation." Chem. Eng. Progress, Vol. 77, No. 5, p. 54.

Walker, W. R., and R. C. Stuart. 1968. "Deep Well Disposal of Waste." J. Sanitary Eng. Div., Proc. American Soc. Civil Engr., Vol. 94, p. 945.

Weaver, D.G., and W. A. Biggs, Jr. 1961. "Pulp-Mi11 Waste Liquor." Ind. Eng. Chem., Vol. 53, No. 10, pp. 773-778.

Wilhelmi, A. R., and R. B. Ely. 1977. "The Treatment of Toxic Industrial Wastewaters by a Two Step Process." Proceedings 30th Industrial Waste Conference, Purdue University. Ann Arbor Science Pubishers, Inc., Ann Arbor, Michigan, pp. 288-295.

Wilhelmi, A. R., and P. V. Knopp. 1979. "Wet Air Oxidation -- An Alternative to Incineration." Chemical Engineering Progress, Vol. 75, pp. 46-52.

Wong, A. L., and B. W. Mercer. 1979. "Contribution of Thiosulf ate to COD and BOD in 0 il Shale Process Wastewater." In Proceedings of American Society for Testing and Materials Symposium on Analysis of Water Associated with Alternate Fuel Production, Pittsburgh, Pennsylvania, June 4 and 5, 1979. 


\section{ACKNOWLEDGMENTS}

The authors extend their appreciation to M. A. Lekas of Geokinetics Inc., R. N. Heistand of Paraho Development Corporation and R. Thomason of Occidental 0il Shale, Inc., for supplying the water samples used in these studies. The efforts of D. A. Berg, K. L. Shupe, D. J. Kennedy and P. C. Young in preparing the manuscript are gratefully acknowledged. 
.

.

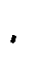

.

,

.

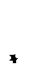




\section{DISTRIBUTION}

No. of

Copies

OFFSITE

27 DOE Technical Information Center

5 Charles Grua

U.S. Department of Energy

EV-142, D-232, GTN

Washington, D.C. 20545

Willard Chappell

The 0il Shale Task Force

University of Colorado at Denver

1100 14th Street, Box 136

Denver, Colorado 80202

Ralph Frank lin

U.S. Department of Energy

EV-34, GTN

Mailstop E201

Washington, D.C. 20545

R. N. He istand

Paraho Development Coporation

Anvil Points, Box A

Rifle, Colorado 81650

Art Hartstein

U.S. Department of Energy

D-107, FE-30, GTN

Washington, D.C. 20545

J. C. Knepper

Rio Blanco Oil Shale Company

Dayton Commons

9725 East Hampden Avenue

Denver, CO 80231

Will Wakamiya

Aerojet General/Sacramento

Environ. Operations

c/o Aerojet Strategic Propulsion, Dept. 9020/Box 43

P.0. Box $15699 \mathrm{C}$

Sacramento, CA 95813
No. of

Copies

M. A. Lekas

Geokinetics, Incorporated

Suite D-2

391 Chipeta Way

Salt Lake City, Utah 84108

K. D. Linstedt

University of Colorado

Boulder, CO 80309

R. E. Poulson

Laramie Energy Research Center

Department of Energy

P.0. Box 3395, University Station

Laramie, WY 82071

T. J. Powers

U.S. Environmental Protection Agency

555 Ridge Avenue

Cincinnati, $\mathrm{OH} 45268$

A. J. Rothman

Lawrence Livermore Laboratory

P.0. Box 808, M.S. L-207

Livermore, CA 94550

R. Thomason

Occidental 0 il Shale Inc.

P.0. Box 2687

Grand Junction, CO 81502

G. Rowe

Exxon Research and Engineering Company

P.0. Box 101

Florham Park, NJ 07932 
No. of

Copies

DOE Richland Operations

H. E. Ranson

37 Pacific Northwest Laboratory

N. E. Bell (2)

C. E. Elderkin

C. J. English

S. Marks

M. J. Mason

B. W. Mercer (15)

R. G. Riley (2)

J. A. Stottlemyre

R. E. Wildung

Technical Information (5)

Publishing Coordination (BE) (2)

Geoscience, Research and

Engineering Dept. Library (5) 